\title{
Hepatic encephalopathy : a new perspective for therapy
}

Citation for published version (APA):

Soeters, P. B. (1979). Hepatic encephalopathy : a new perspective for therapy. [Doctoral Thesis, Maastricht University]. Rijksuniversiteit Limburg. https://doi.org/10.26481/dis.19790403ps

Document status and date:

Published: 01/01/1979

DOI:

10.26481/dis.19790403ps

Document Version:

Publisher's PDF, also known as Version of record

\section{Please check the document version of this publication:}

- A submitted manuscript is the version of the article upon submission and before peer-review. There can be important differences between the submitted version and the official published version of record.

People interested in the research are advised to contact the author for the final version of the publication, or visit the DOI to the publisher's website.

- The final author version and the galley proof are versions of the publication after peer review.

- The final published version features the final layout of the paper including the volume, issue and page numbers.

Link to publication

\footnotetext{
General rights rights.

- You may freely distribute the URL identifying the publication in the public portal. please follow below link for the End User Agreement:

www.umlib.nl/taverne-license

Take down policy

If you believe that this document breaches copyright please contact us at:

repository@maastrichtuniversity.nl

providing details and we will investigate your claim.
}

Copyright and moral rights for the publications made accessible in the public portal are retained by the authors and/or other copyright owners and it is a condition of accessing publications that users recognise and abide by the legal requirements associated with these

- Users may download and print one copy of any publication from the public portal for the purpose of private study or research.

- You may not further distribute the material or use it for any profit-making activity or commercial gain

If the publication is distributed under the terms of Article $25 \mathrm{fa}$ of the Dutch Copyright Act, indicated by the "Taverne" license above, 
Peter B. Soeters. 
Hepatic encephalopathy a new perspective for therapy.

Proefschrift

ter verkrijging van de graad van Doctor in de

Geneeskunde aan de Rijksuniversiteit Limburg te

Maastricht op gezag van de rector magnificus

Prof. Dr. W.H.F.W. Wijnen, hoogleraar in de Faculteit

der Geneeskunde, en volgens besluit van het

College van Dekanen.

De openbare verdediging zal plaatsvinden op

dinsdag 3 april 1979 des namiddags te 16.00 uur.

door

P.B. Soeters

geboren te Amsterdam. 
Promotores: Prof. Dr. J.M. Greep

Prof. J.E. Fischer (Cincinnati)

Referenten: Dr. R. Grijm

Dr. K.-H. Brandt

The clinical and experimental studies were performed at the Departments of Surgery and Medicine and the Surgical Physiology Laboratory of the Massachusetts General Hospital and Harvard Medical School in Boston (U.S.A.). 
To Antje, Maarten and Peter-Jan. 
Parts of this thesis were published or will be published in the following journals or books:

1. M.G. Cummings, J.H. James, P.B. Soeters, J.M. Keane, J. Foster and J.E. Fischer.

Regional brain study of indoleamine metabolism in the rat in acute hepatic failure.

J. Neurochem. 27:741, 1976.

2.P.B. Soeters, J.E. Fischer.

Insulin, glucagon, amino acid imbalance, and hepatic encephalopathy. Lancet II:888,1976.

3. J.E. Fischer, H.M. Rosen, A.M. Ebeid, J.H. James, J.M. Keane, and

P.B. Soeters.

The effect of normalization of plasma amino acids on hepatic

encephalopathy.

Surgery 80:77, 1976.

4. M.G. Cummings, P.B. Soeters, J.H. James, J.M. Keane and J.E. Fischer. Regional brain indoleamine metabolism following chronic porta-caval anastomosis in the rat.

J. Neurochem. 27:501, 1976.

\section{P.B. Soeters.}

Parenteral nutrition in hepatic failure.

In: Current Concepts in Parenteral Nutrition, edited by J.M. Greep et al., Martinus Nijhoff, Medical Division, The Hague 1977, p. 159.

6. P.B. Soeters, G. Weir, A.M. Ebeid, and J.E. Fischer. Insulin, glucagon, portal systemic shunting and hepatic failure in the dog. J. Surg. Res. 23:183, 1977.

7. H.M. Rosen, P.B. Soeters, J.H. James, J. Hodgman-M. Keane and J.E. Fischer.

Influences of exogenous intake and nitrogen balance on plasma and brain aromatic amino acid concentrations.

Metabolism 27:393, 1978.

8. P.B. Soeters, A.M. Ebeid, J. Hodgman-M. Keane, J.H. James and J.E. Fischer. Effects of specific amino acid-glucose infusions in treatment of hepatic encephalopathy following porta-caval shunt: A cross-over study.

Submitted to Annals of Surgery. 


\section{Contents}

Page

Preface

Chapter 1: Introduction 3

1.1. General introduction 3

1.2. Current hypotheses concerning the genesis of 4

hepatic encephalopathy.

1.2.1. Ammonia hypothesis 4

1.2.2. Short-chain - fatty acid hypothesis and the $\quad 5$

free fatty acid, ammonia, mercaptans hypothesis.

1.2.3. Ammonia acid-neurotransmitter 6 hypothesis.

Chapter 2: Relief of hepatic encephalopathy with specific

amino acid - glucose mixtures in dogs with portacaval shunts.

2.1. Introduction

2.2. Materials and methods

2.3. Laboratory analysis

2.4. Results

14

2.5. Discussion

15

2.6. Summary

Chapter 3: Insulin, glucagon, portal systemic shunting and 35 hepatic failure in the dog.

3.1. Introduction

3.2. Methods 35

3.3. Results

3.4. Discussion 38

3.5. Summary $\quad 40$

Chapter 4: Relief of hepatic encephalopathy with specific 41

amino acid - glucose mixtures in man.

4.1. Introduction 41

4.2. Materials and methods 41

4.3. Results 43

4.4. Discussion $\quad 56$

4.5. Summary $\quad 58$ 
Chapter 5: Influences of exogenous intake and nitrogen-

balance on plasma - and brain aromatic amino

acid concentrations in rats with porta-caval shunts

5.1. Introduction

5.2. Materials and methods

5.3. Results

5.4. Discussion 65

5.5. Summary 69

Chapter 6: Leucine metabolism and porta-caval shunt in the 71

rat.

6.1. Introduction 71

6.2. Materials and methods $\quad 71$

6.3. Results 72

6.4. Discussion $\quad 75$

6.5. Summary $\quad 76$

Chapter 7: Comprehensive interpretation of the pertinent 77

experimental data : summary

7.1. Metabolic abnormalities in hepatic 77 encephalopathy

7.2. Amino acid-glucose infusions $\quad 80$

7.3. Clinical practice 81

7.4. Validity hepatic encephalopathy hypotheses 83

$\begin{array}{ll}\text { Summary } & 85\end{array}$

$\begin{array}{ll}\text { Samenvatting } & 89\end{array}$

$\begin{array}{ll}\text { References } & 93\end{array}$

$\begin{array}{ll}\text { Curriculum vitae } & 105\end{array}$ 


\section{Preface}

This thesis would never have been written if it were not for Co Greep, who always makes me and made me do things that I thought I could not do or did not want to do. Therefore, I gratefully acknowledge his pushing and shoving. Joe Fischer provided me with every opportunity that I wanted, to complete the work compiled in this thesis and it is under his guidance and in his laboratory, that this work was performed.

Many of the ideas put forward in this thesis found their origin in lengthy and pleasant conversations with Amin Ebeid, in collaboration with whom many of the experiments were carried out.

Jane Hodgman - M. Keane and Howard James equally contributed to this thesis with expert technical and theoretical assistance.

Gerda Haemers transformed in her own inimitable way, the manuscript from an illegible scribble into its present form.

Finally, I would like to aknowledge the indirect help of my parents who by their inspiring example taught me to love our beautiful profession. 


\section{Chapter 1}

\section{Introduction}

\subsection{General Introduction}

The elucidation of the pathogenesis of hepatic encephalopathy has through the decades for, obvious reasons been hampered by the problems inherent to studying metabolic processes in the brain. Research in this area is very much like looking through the keyhole of a door into a room, spotting at the opposite side of that room a second door with a second keyhole, and studying through that second keyhole the events occurring in a second room. Research in hepatic encephalopathy therefore has generally limited itself to a search for parameters, correlating with the grade of hepatic encephalopathy. Herewith, a second problem arises: quantifying the grade of encephalopathy. Any technique used in trying to quantify hepatic encephalopathy has its own pitfalls and can at best give an approximation of the grade of encephalopathy. A third problem is that it is not certain that the dynamics underlying hepatic encephalopathy are the same in all patients with hepatic failure. If there is more than one pathway along which hepatic encephalopathy develops, finding a specific parameter may become impossible.

As a next step in clinical "hepatic coma" research, generally therapies were devised to improve the parameter. When a good correlation was observed between improvement in encephalopathy and parameters, not infrequently the erroneous conclusion was drawn that the parameter was the cause of encephalopathy. The validity of a hypothesis concerning hepatic encephalopathy is therefore generally judged by the success of the therapy based on the hypothesis. This cannot be concluded however, because the therapy that was instituted generally induced a multitude of metabolic events that precluded the possibility to pinpoint one metabolic substrate as the only or even an important cause of encephalopathy. In addition, it implies the necessity to study hepatic encephalopathy in the intact experimental animal, preferably species exhibiting quantifyable encephalopathy. This induces several problems not the least of which are the costs and space requirements involved.

The primate model and most other species preclude the possibility of studying brain metabolism at the tissue level because more invasive techniques interfere with the integrity of the brain and thus the organism and secondly because brains in the larger species cannot be isolated fast enough after sacrifice before major changes have taken place that make further study impossible. Only a freeze-blow technique employed in rats allows study of brain-energy metabolism that is representative for the living state. Inherent to the animal model in general however is the question, how valid is the model, and is it legitimate to transpose the results derived from the experimental model to man? One more complicating factor in elucidating hepatic encephalopathy should be mentioned.

One of Koch's postulates states that an agent when infused, should elicit the 
phenomenon that was observed together with the occurrence and growth of the agent. This criterion has been applied in several areas of medicine including hepatic encephalopathy. Several substances have been infused in intact animals to mimick hepatic encephalopathy, and to serve as proof for the claim that the infused substance may be the cause of hepatic encephalopathy. The significance of such studies is questionable, and conclusions drawn on the basis of such studies are invalid, because they are an oversimplification of the situation that is meant to be studied.

A given substance may be toxic under certain circumstances, comprising flux, direction of flux, transport over membranes, accessibility of systems that metabolize the given substance, hormonal profiles etc.... In the intact animal for instance, toxicity may not be present, even though plasma levels may be reached that are much higher than levels encountered when a toxic effect is observed in organisms with hepatic failure.

In conclusion, when studying hepatic encephalopathy, we are liable to commit mistakes, and to draw erroneous conclusions especially with regard to the pathogenesis of hepatic encephalopathy itself. We will commit many of these potential errors, jumping from patients to animals, use the one species after the other, use a model that may not be valid etc. . We will not however pinpoint one substance as cause for hepatic encephalopathy; rather will we describe a treatment that allows us to feed patients and animals with hepatic encephalopathy without the obligatory occurrence of hepatic encephalopathy.

In addition, we will try to define possible mechanisms underlying this observation. This will shed light on systemic metabolic events occurring in hepatic encephalopathy, and on the common denominator of seemingly unrelated factors precipitating hepatic encephalopathy, rather than causing it. In consequence, the mechanism at the brain level will not be dealt with in great detail.

\subsection{Current hypotheses concerning the genesis of hepatic encephalopathy.}

\subsubsection{Ammonia hypothesis.}

Traditionally, ammonia has been incriminated as the principal aetiologic factor in the pathogenesis of hepatic encephalopathy for three reasons: 1) A reasonably good correlation could be demonstrated between plasma ammonia levels and the degree of hepatic encephalopathy $(1,2)$.

2) Measures that were considered to be specifically devised to diminish plasma ammonia levels proved to be efficacious in the treatment of hepatic encephalopathy and

3) potential sources of ammonia (meat, blood) were shown to cause encephalopathy $(3,4)$. All these considerations suffer from methodological problems that we mentioned in the first part of this chapter: 
ad 1) Well correlating parameters are not necessarily causative agents. ad 2) Measures taken to diminish plasma ammonia levels were by no means specific.

ad 3 ) Is is clear that the administration of meat elicits a multitude of metabolic sequelae, excluding the possibility to consider one separate metabolic phenomenon.

The next question that was raised was: if ammonia is an important aetiologic agent, what mechanism underlies this effect? Traditionally mechanisms that were considered have almost invariably implicated interference with energy metabolism as the cause of neurologic disorders (5). Reports on total brain consumption of glucose and oxygen are contradictory $(6,7,8,9)$, one suggesting a decrease prior to coma, others reporting no differences during the first $24 \mathrm{hrs}$. After $24 \mathrm{hrs}$ of coma, brain consumption of oxygen and glucose decrease, suggesting that this decrease is the result rather than the cause of coma. Regional studies in rat brains after acute ammonia poisoning showed changes in energy charge (10). These studies however again suffer from methodological errors as rapid changes in labile intermediates occur during processing of the brains.

In an acute hepatic coma rat model, rapid freezing methods were used to harvest the brain within 1 second $(11,12,13)$. This method precludes regional dissection but yields reliable measures for energy charge showing that no major changes occurred when care was taken to prevent hypoglycemia. As a consequence, it is hard tot uphold theories implicating ammonia-induced depletion of $\alpha$-ketoglutarate (5), acetyl-co A etc. . . as a cause of hepatic encephalopathy.

1.2.2. Short-chain - fatty acid hypothesis and the free fatty acid, ammonia, mercaptans hypothesis.

Short-chain fatty acids have been suggested as an aetiologic factor in hepatic encephalopathy $(14,15,16)$. Concentrations of these fatty acids (butyrate, valerate, and octanoate) are increased in the cerebrospinal fluid and blood of patients in hepatic encephalopathy $(15,16)$, presumably because they escape degradation due to spontaneous or surgically induced portal systemic shunting of splanchnic blood or due to an impaired liver function per se. Little evidence exists to sustain this theory. The correlation between the plasma levels and liquor levels (17) of these short-chain fatty acids and the grade of encephalopathy is poor. Moreover, the levels of branched-chain short-chain fatty acids in Jamaican vomiting sickness (18) or isovaleric acidemia (19) are hundreds of times in excess of levels of shortchain fatty acids in hepatic coma. Nor is there an evident relation between coma-precipitating factors and short-chain fatty acids. Finally, no attempt as yet has been made to elucidate the mechanism that might be involved in the proposed toxic action of short-chain fatty acids. Thus, apart from a correlation (20), there is not much to sustain the short-chain fatty acid theory. Synergism between ammonia, free fatty acids, and mercaptans has been evoked in the genesis of hepatic coma (14). Normal rats have been made 
comatose by injection of combinations of these substances, but no other evidence exists supporting this theory.

\subsubsection{Amino acid - neurotransmitter hypothesis.}

It is perplexing that through the decades, efforts to explain hepatic encephalopathy have focused mainly on interference with energy metabolism. It is in our opinion the merit of the "amino acid - neurotransmitter theory" that it tries to explain hepatic encephalopathy via interference with physiological neurotransmitter metabolism, supposedly responsible for consciousness, physiological sleep etc. . .

The "amino acid - neurotransmitter hypothesis" claims that the pathologic amino acid pattern reported in hepatic encephalopathy, is responsible for changes in concentration of physiological and non-physiological neurotransmitters in the brain. These changes, in turn, might be responsible for hepatic encephalopathy. A derangement in neurotransmitter profile has been reported in animals and patients with hepatic encephalopathy $(21,22$, 23 ,24). Thus, after a two stage ligation of hepatic blood supply resulting in acute hepatic coma, norepinephrine, a putative adrenergic neurotransmitter, is decreased, whereas octopamine, a substance with weak neurotransmittter function (25), is markedly increased $(21,23,24,26)$. Serotonin, an inhibitory transmitter which may replace norepinephrine in adrenergic neurons $(20$, 27 ), is increased as well, but not to the same degree as the $\beta$-hydroxylated false neurochemical transmitters $(23,24,26,28,29,30)$. In man, a good correlation was demonstrated between urinary excretion of octopamine $(23$, 26) and blood concentrations of octopamine in patients with hepatic encephalopathy and normal renal function $(23,24,31,32)$. It was noted (21) that the accumulation of octopamine in the brain preceded any accumulation in the serum $(21,26)$. This suggests that such changes occur in the brain itself, even more so because amines do not cross the blood-brain barrier significantly (33). Therefore it is claimed in the amino acid - neurotransmitter hypothesis that the alterations, responsible for the changes in synthesis of norepinephrine and octopamine most likely involve their precursors, the aromatic amino acids which are greatly increased in the plasma and the central nervous system of patients and experimental animals in hepatic encephalopathy $(28,34,35)$. In hepatic encephalopathy, a characteristic plasma amino acid pattern is observed especially comprising changes in the neutral amino acids (figure 1), notably elevations in the aromatic amino acids (tyrosine, tryptophan and phenylalanine) $(28,34,35)$ and decreases in the branched-chain amino acids (leucine, isoleucine and valine) $(28,35,36,39$, 40). These neutral amino acids compete for entry across the blood-brain barrier $(41,42,43,44)$, so that changes in the plasma pattern may reflect in the brain. Tyrosine is a normal precursor of the catecholamines (figure 2), including the putative transmitters dopamine and norepinephrine, and tryptophan is the precursor of serotonin, another physiological neurotransmitter.

Recent work from this laboratory as well as from others, has suggested that although under normal circumstances, tyrosine is preferentially synthetized 
to catecholamines, when tyrosine accumulates, it appears preferably to be metabolized to octopamine $(45,46,47)$. In rats with porta-caval shunts and hepatic insufficiency, an excellent correlation between brain tyrosine and octopamine has been demonstrated (47). This is explained partially by the fact that in rats the $\mathrm{kM}$ for tyrosine-3-hydroxylase is close to the normal brain concentrations of tyrosine. In hepatic encephalopathy, tyrosine increases markedly (48). Most of this increased tyrosine is decarboxylated to tyramine by an L-aromatic amino acid decarboxylase whose $\mathrm{kM}$ is much higher and whose capacity far exceeds 3-hydroxylation, the competing pathway of tyrosine (45). This would explain increased synthesis of octopamine (figure 2). Decreases in norepinephrine in brains of animals in acute hepatic coma are probably due to decreased synthesis (21). Increased brain concentrations of phenylalanine may inhibit the hydroxylation of tyrosine to

\section{NEUTRAL AMINO ACIDS}

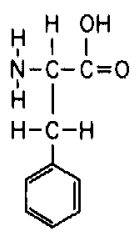

PHENYLALANINE<smiles>NCC(O)C(=O)O</smiles>

TYROSINE

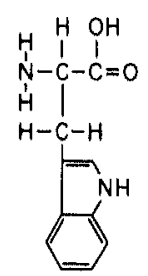

TRYPTOPHAN

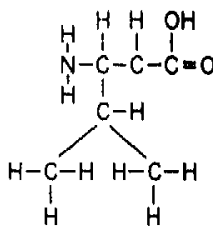

$V A L I N E$<smiles>C=CC(NNC(C=CC(F)(F)F)C(=O)O)C(F)(F)F</smiles>

LEUCINE

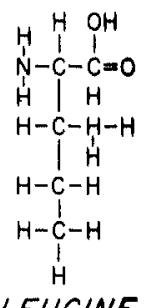

ISOLEUCINE

Figure 1: Structure of aromatic amino acids (left) and branched-chain amino acids (right). 
dihydroxyphenylalanine, by directly competing with tyrosine for the enzyme tyrosine hydroxylase, since tyrosine and phenylalanine have similar affinities for this enzyme. In addition, increased brain concentrations of phenylalanine may lead to the formation of phenylethanolamine (figure 2) another amine with weak neurotransmitter function. Tryptophan, in addition to its ability to increase brain serotonin, inhibits the hydroxylation of tyrosine to dopa, so that the excess accumulation of tryptophan in the brain in hepatic coma may further inhibit catecholamine synthesis. Farther along the synthetic pathway, 5-hydroxy-tryptophan and aromatic amino acid "false" neurotransmitter precursors could compete with dopa for decarboxylation to dopamine. Finally, alternative neurochemical transmitter-amines would further inhibit the synthesis of norepinephrine at the dopamine $\beta$-hydroxylase step. It is controversial what determines brain tryptophan and serotonin levels. Some have claimed that the main tryptophan penetration across the bloodbrain barrier is the ratio of free: bound tryptophan $(41,49)$, a relationship which is altered in acute hepatic failure (50). Others have claimed that tryptophan penetration into the brain is determined by the plasma

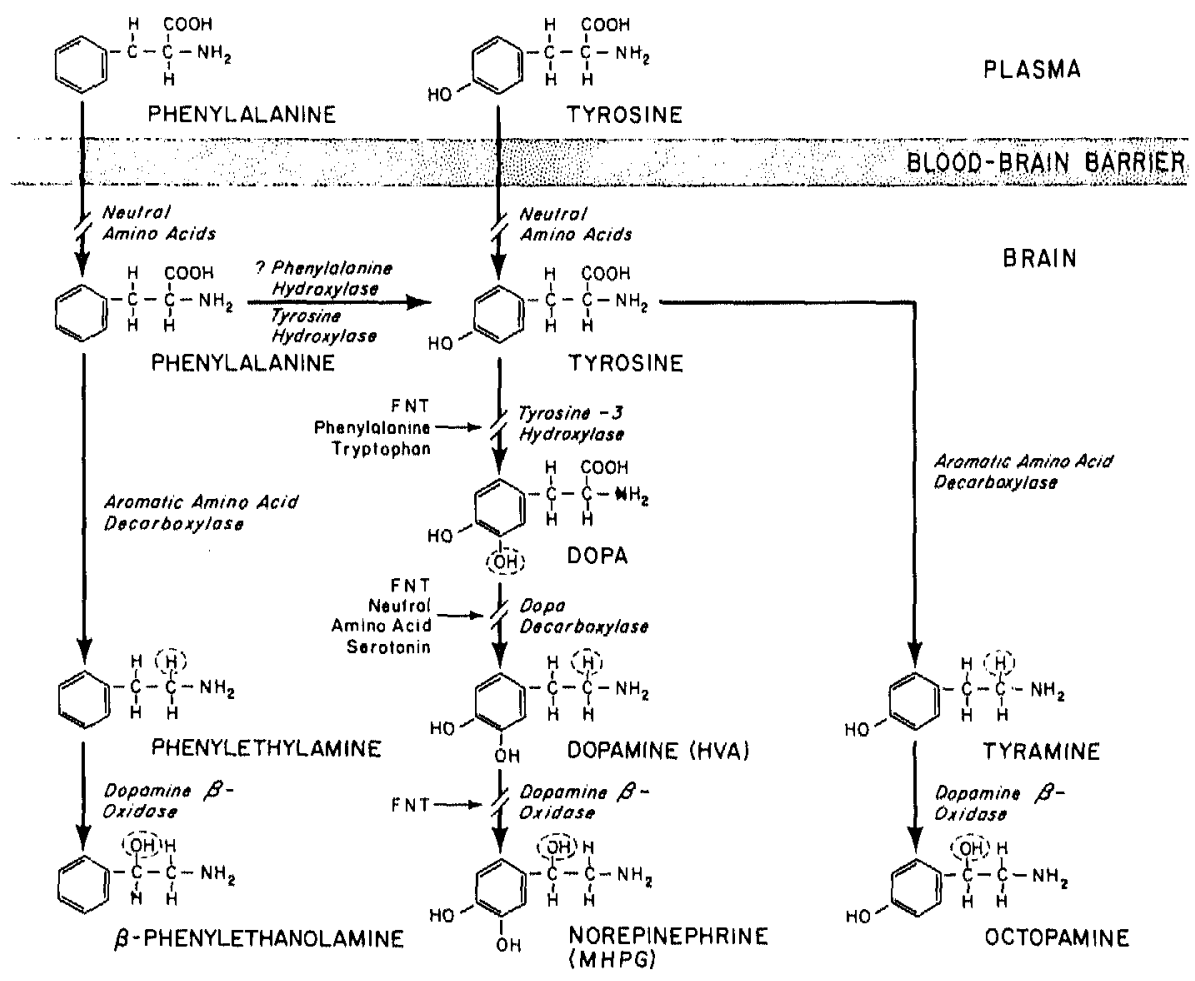

Figure 2: Synthetic scheme of catecholamines in brain. Although tyrosine is normally the principal precursor for catecholamines, phenylalanine that is hydroxylated to tyrosine may similarly serve as a precursor for catecholamine synthesis. When tyrosine accumulates, it may be preferentlally decarboxylated to tyramine and then to octopamine. Potential or actual synthetic blocks are shown by slashes at the verious enzymatic points. 
concentrations of the neutral amino acids $(41,47)$. Our own work suggests, that under acute circumstances, the ratio of free: bound tryptophan adequately explains the increased tryptophan in acute hepatic coma (51). With chronic hepatic insufficiency (52), the ratio of the neutral amino acids appears of greater importance than free: bound tryptophan in explaining increased brain tryptophan. It is possible to decrease brain tryptophan over 4 hours in rats with chronic hepatic insufficiency by the administration of the branched-chain amino acids alone (52). This and other data (47) suggest that the branched-chain amino acids may be the most important neutral amino acid group in competing with the aromatic amino acids for entry across the blood-brain barrier.

If the deranged plasma amino acid pattern in hepatic encephalopathy is related causally to hepatic encephalopathy, then normalization of the plasma amino acid pattern might result in improvement of hepatic encephalopathy. Normalization of the plasma amino acid pattern was pursued by parenteral administration of a glucose - amino acid solution roughly containing the mirror image of the plasma amino acid pattern.

Results with this solution in dogs, are described in chapter 2. Chapter 4 comprises the results with the same solution in a pilot study in patients with alcoholic cirrhosis or acute fulminant hepatitis.

The apparent beneficial effect of the solution (chapter 2 and 4) raises two questions:

1. What causes the pathological plasma amino acid pattern? In chapter 3 we will try to define plasma amino acid changes in dogs subjected to porta-caval shunt and in hepatic encephalopathy, and the possible relationship with changes in plasma insulin- and -glucagon levels. The mechanism involved in the decrease in plasma branched-chain amino acid levels has been subject to speculation. In chapter 6 , we will describe experiments to elucidate this problem.

2. What mechanism underlies the beneficial effect of the solution? In chapter 5 , we will describe experiments in rats that were carried out to investigate the role of anabolism.

On the basis of these experiments (chapters 2, 3, 4, 5, and 6) and of the literature, an extrapolative view will be given in chapter 7 on systemic metabolic events occurring in hepatic encephalopathy, on the common denominator of factors precipitating hepatic encephalopathy, and on mechanisms involved in the results obtained with the specific glucoseamino acid mixture. 



\section{Chapter 2}

Relief of hepatic encephalopathy with specific amino acid-glucose mixtures in dogs with porta-caval shunts.

\subsection{Introduction}

In most institutions, current treatment of hepatic encephalopathy still consists of protein restriction, despite the fact that patients suffering from hepatic encephalopathy are generally malnourished and in negative nitrogen balance. Indeed, patients with marginal liver function due to chronic liver cirrhosis are apt to develop hepatic encephalopathy when ingesting too much protein.

Table 1:

Composition of amino acid mixtures

\begin{tabular}{|c|c|c|}
\hline & $\begin{array}{l}\text { Commercial solution } \\
1000 \mathrm{ml}\end{array}$ & $\begin{array}{c}\text { Hepatic } \\
\text { failure solution } \\
1000 \mathrm{ml}\end{array}$ \\
\hline \multicolumn{3}{|l|}{ L-Essentials } \\
\hline L-Isoleucine & 1.48 & 4.50 \\
\hline L-Leucine & 1.93 & 5.50 \\
\hline L-Lysine-HCl & 1.93 & 3.80 \\
\hline L-Methionine & 1.12 & 0.50 \\
\hline L-Phenylalanine & 1.20 & 0.50 \\
\hline L-Threonine & 0.85 & 2.25 \\
\hline L-Tryptophan & 0.32 & 0.38 \\
\hline L-Valine & 1.40 & 4.20 \\
\hline \multicolumn{3}{|l|}{ Non-Essentials } \\
\hline L-Alanine & 1.50 & 3.75 \\
\hline L-Arginine & 0.77 & 3.00 \\
\hline L-Histidine & 0.60 & 1.20 \\
\hline L-Proline & 2.38 & 4.00 \\
\hline L-Serine & 1.25 & 2.50 \\
\hline Glycine & 4.50 & 4.50 \\
\hline $\mathrm{L}$-Cysteine. $\mathrm{HCl} . \mathrm{H}_{2} \mathrm{O}$ & 0.01 & 0.20 \\
\hline \multicolumn{3}{|l|}{ Glucose $23 \%$} \\
\hline Electrolytes & & \\
\hline
\end{tabular}

Table 1: Composition of the special "hepatic failure solution" (FOBO) and the "commerclal solution" (Freamine II) used in these studies. 
On the basis of the "amino acid - neurotransmitter theory", an amino acidglucose mixture was devised, roughly calculated to normalize the pathologic plasma amino acid pattern that we referred to in chapter 1 . This mixture contains extra branched-chain amino acids; the aromatic amino acids are largely omitted (table 1).

In an earlier report (53), results with this mixture were reported in dogs with porta-caval shunts, showing that all dogs, receiving the specific mixture $(4 \mathrm{~g}$ protein $/ \mathrm{kg} / 24 \mathrm{hrs}$ ) survived, whereas the control group exhibited a high mortality, receiving a commercially available solution in isonitrogenous, isocaloric amounts (table 2). A group of dogs receiving glucose $23 \%$ and albumin showed a mortality which was significantly elevated compared with the group receiving the specific solution. The objection was raised against this protocol, that the control group received too much protein $(4 \mathrm{~g} / \mathrm{kg} /$ $24 \mathrm{hrs}$ ) and that perhaps a lucky randomization might have occurred.

Table 2:

Survival (dogs with porta-caval shunts)

\begin{tabular}{lc}
\hline & $\begin{array}{c}\text { Died in hepatic comal } \\
\text { Total }\end{array}$ \\
\hline I. $23 \%$ Dextrose + Albumin & $2 / 5$ \\
II. Commercial glucose amino acid mixture & $11 / 13$ \\
III. Hepatic failure glucose amino acid mixture & $0 / 8$ \\
\hline
\end{tabular}

Table 2: Mortality in dogs with porta-caval shunts, infused with three different types of solution. Note that none of the dogs that were infused with hepatic failure solution died. Of the 13 dogs that were infused with a commercial solution, 11 died within 30 days.

Therefore, this study was undertaken to compare in severely encephalopathic dogs the effect of the specific solution (Hepatic Failure Solution; F080) given in supranormal amounts ( $4 \mathrm{~g}$ amino acids $/ \mathrm{kg} / 24 \mathrm{hrs}$ ), with conventional infusional therapy (Commercial Solution; Freamine II) consisting of hypertonic glucose and smaller doses of amino acids $(2 \mathrm{~g}$ amino acids $/ \mathrm{kg} / 24$ $\mathrm{hrs}$ ), which in dogs of the size employed is equivalent to protein restriction.

\subsection{Materials and methods}

Experimental design: conditioned mongrel dogs weighing $16-20 \mathrm{~kg}$ were anaesthetized with intravenous surital (a short acting barbiturate), intubated with a cuffed endo-tracheal tube and allowed to breath spontaneously. Through a midline upper abdominal incision, an end-to-side porta-caval shunt was performed. After the procedure, animals recovered quickly, resumed daily activities and recovered appetite. They were maintained on regular Purina dog chow and water. 
After varying periods of time after operation (4 weeks to 6 months) dogs developed encephalopathy. Grades of encephalopathy were clinically assessed by two independent observators according to table 3 . As in previous studies, some dogs never developed encephalopathy; in general these were young dogs, about 1 year old. When the dogs had developed evident hepatic encephalopathy (at least stage II) they were randomly allocated to either of two groups:

1. one group receiving F080 $4 \mathrm{~g}$ protein $/ \mathrm{kg} / 24 \mathrm{hrs}+23 \%$ glucose.

2. one group receiving Freamine $/ 12 \mathrm{~g}$ protein $/ \mathrm{kg} / 24 \mathrm{hrs}+23 \%$ glucose.

Treatment in the second group corresponds with more conventional treatment of hepatic encephalopathy consisting of administration of high doses of glucose and smaller doses of protein. After 12 days of infusion of the initial solution, both groups were switched to the other mixture if the dogs were still alive. One dog, who did not improve with conventional treatment was switched over to the hepatic failure solution (F080) after 4 days, whereafter consciousness was quickly regained. After two days, he was switched back to the commercial solution (Freamine II) which precipitated coma again. Solutions were administered through lines placed via a cutdown in the internal jugular vein into the superior caval vein. Lines were tunnelled subcutaneously to a point between the shoulder blades where they were led out of the skin to an infusion apparatus which was attached to a harness, leaving the dog freely movable. Continuous and precise infusion rate was safeguarded with Holter pumps. Dogs were placed in metabolic cages which allowed collection of urine for nitrogen balances.

Before encephalopathy developed, blood samples were drawn weekly, and before shunt in the morning in the post-absorptive state. When the dogs had developed encephalopathy and were put on line, blood samples were taken on Mondays, Wednesdays and Fridays for analysis of:

Hct, $\mathrm{NH}_{3}$, amino acids, bilirubine, LDH, SGOT, SGPT, triglycerides, cholesterol, free fatty acids (FFA), total protein, albumin, globulin, PTT, unless dogs deteriorated rapidly in which case additional samples were taken. Body weights were determined weekly. Biopsy specimens were obtained from the liver at the time of porta-caval shunt and at autopsy.

Table 3:

Estimation encephalopathy

\begin{tabular}{ll}
\hline Stage 0 & - Normal \\
Stage I & - Delayed response, less lively, diminished appetite, but no \\
& obvious neurological symptoms. \\
Stage II & - Unsteady gait, "blind" to obstacles (goes through them \\
& instead of around them), often profuse salivation. \\
Stage III & $\begin{array}{l}\text { - Sleeps most of the time, difficult to arouse, salivating in } \\
\text { most cases. }\end{array}$ \\
Stage IV & - Unresponsive coma. \\
\hline
\end{tabular}

Table 3: Scheme to assess stage of encephalopathy. 


\subsection{Laboratory analysis}

Urinary nitrogen was determined according to the micro Kjeldahl method. Plasma amino acid levels were determined in a Beckman $121 \mathrm{mB}$ amino acid analyzer. Total tryptophan was measured fluorometrically according to the method of Dencla and Dewey (55). Plasma ammonia was determined according to standard methods (138).

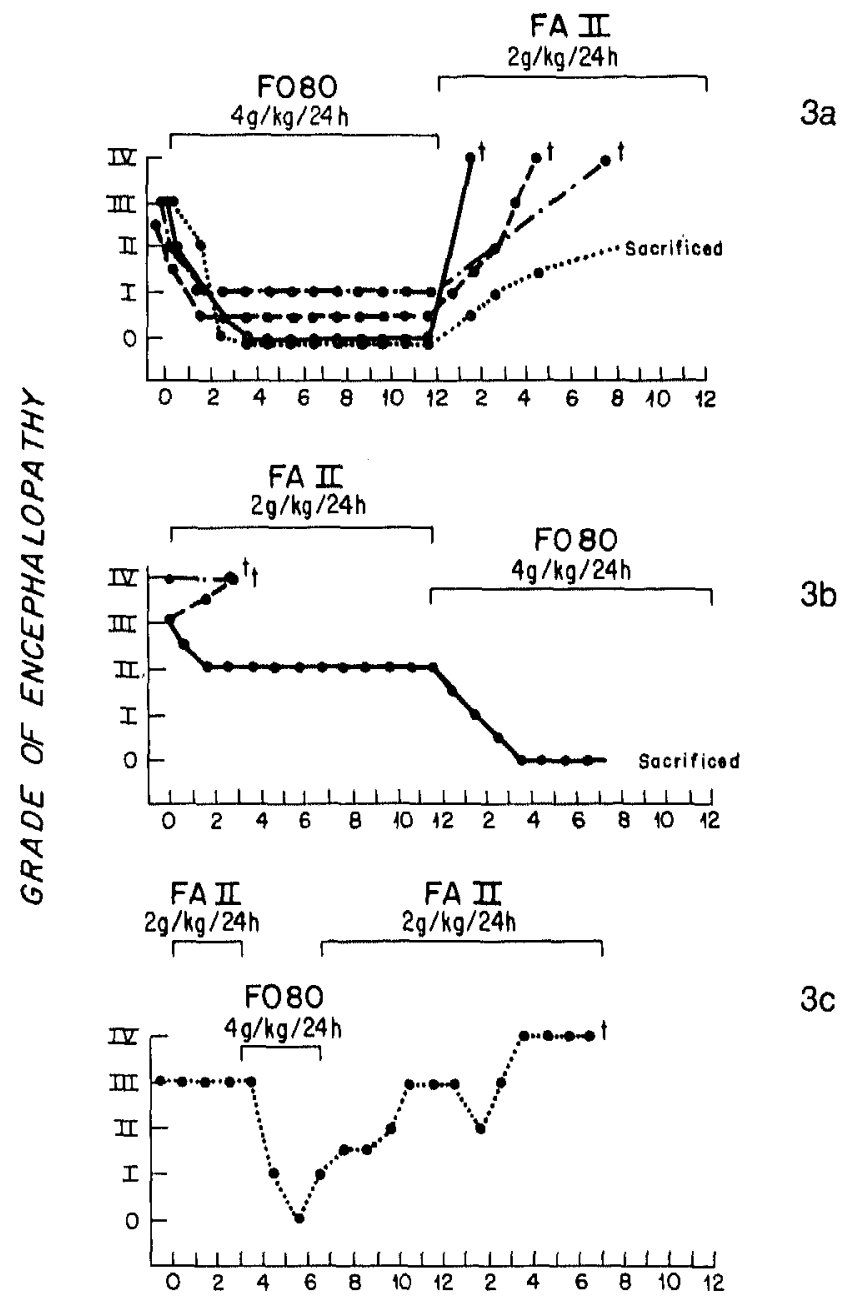

DAYS AFTER THE START OF INTRAVENOUS THERAPY

Figure 3: Grades of encephalopathy after intravenous therapy. 


\subsection{Results}

\section{Encephalopathy}

Of the 8 dogs in the study, 4 were started on F080, and 4 on Freamine II $(2 \mathrm{~g} / \mathrm{kg} / 24 \mathrm{hrs})$. Results are shown in figure 3 . Two dogs receiving Freamine II died after two days (figure $3 \mathrm{~b}$ ), 1 dog stayed in stage II for 12 days, regaining complete consciousness after receiving F080 (figure $3 \mathrm{~b}$ ) and one dog stayed

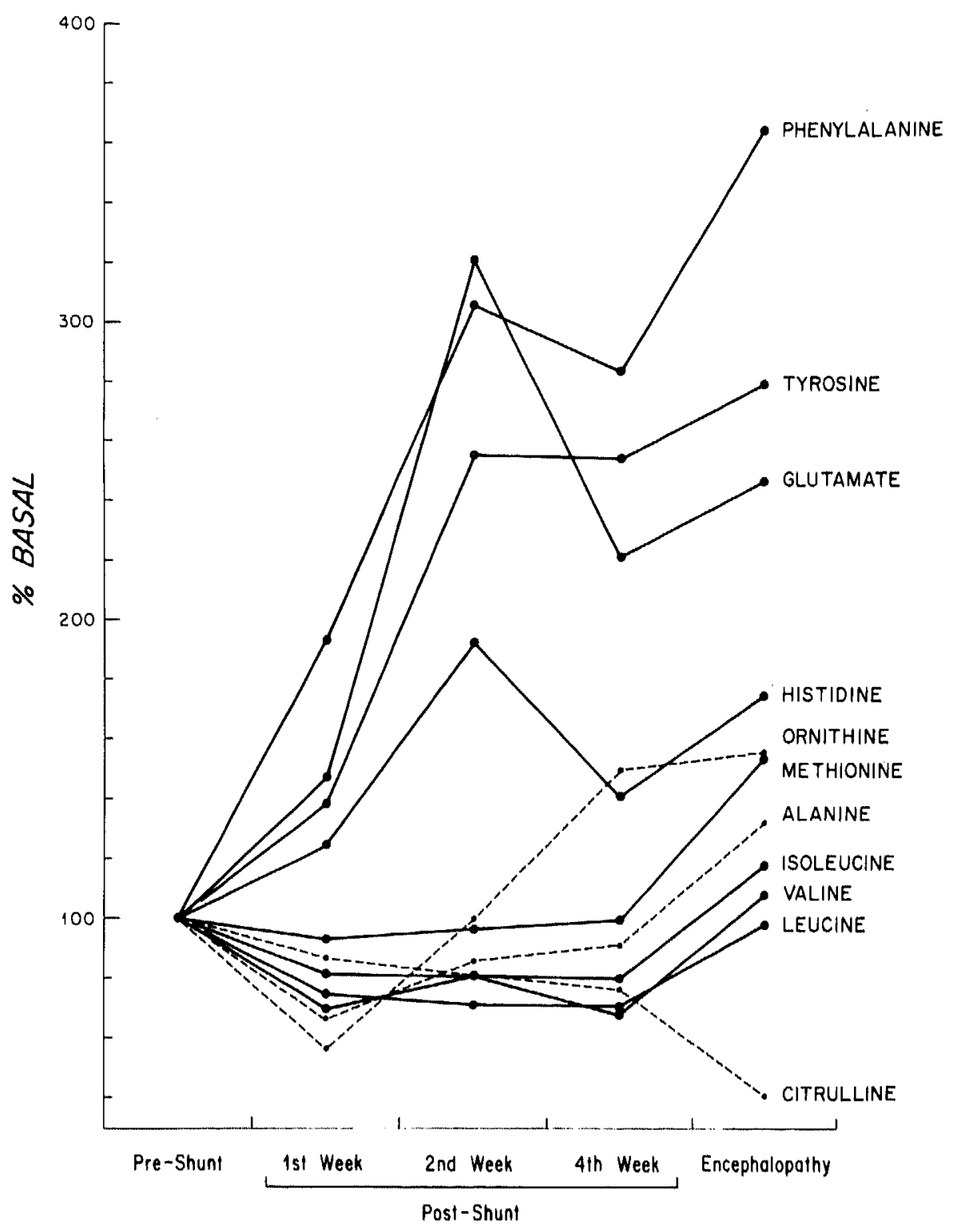

Figure 4: Plasma amino acid levels expressed as percentage of normal, preshunt, 1,2 , and 4 weeks after shunt and in hepatic encephalopathy. 


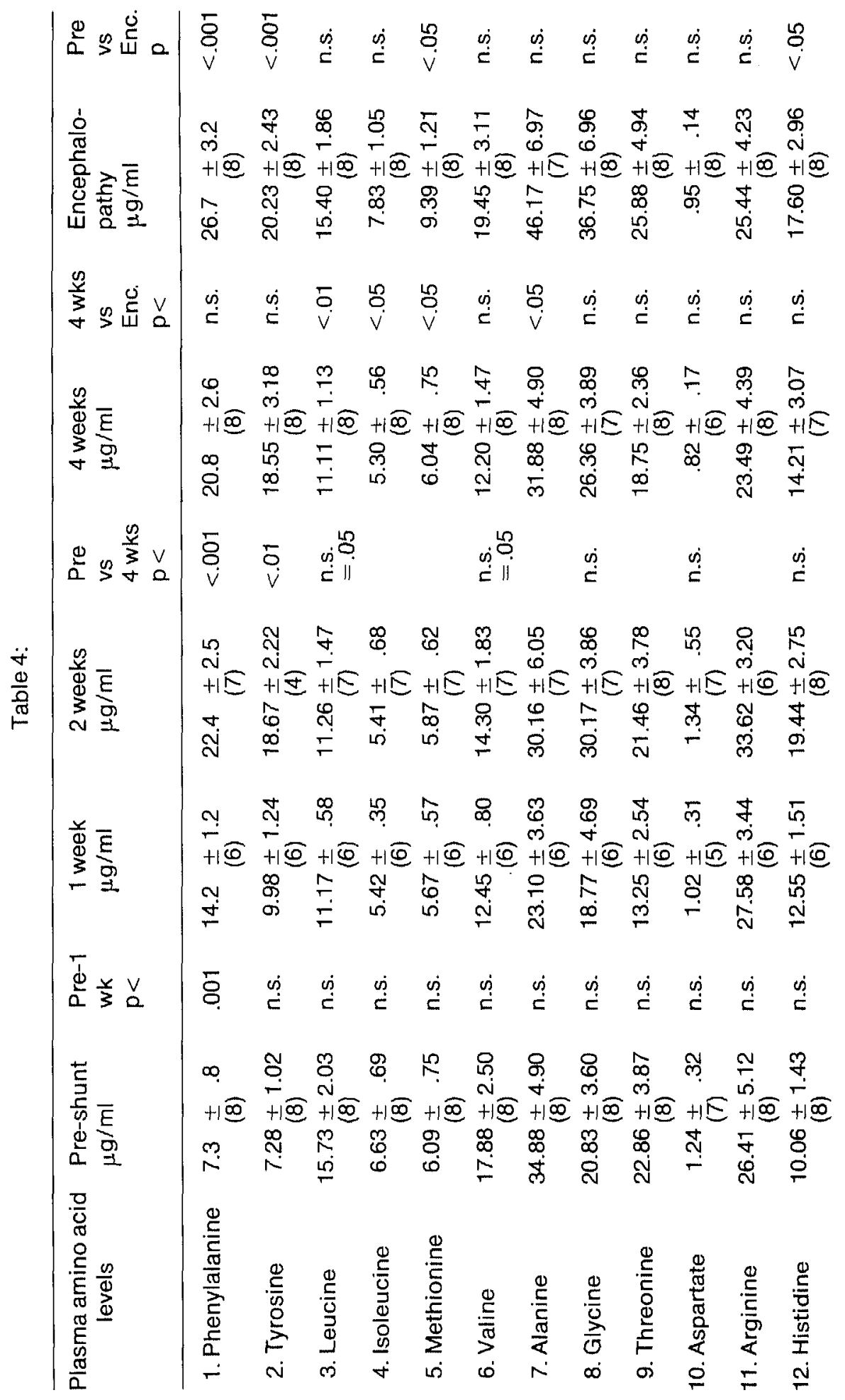




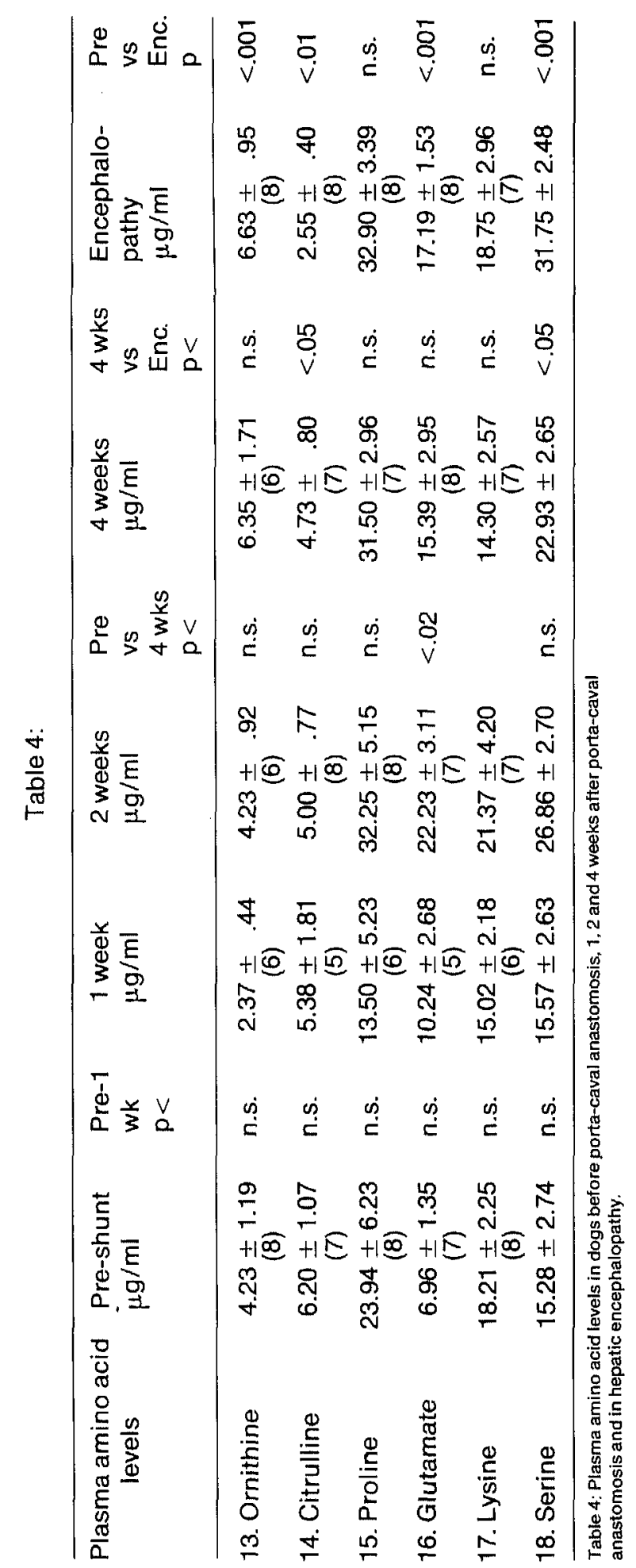


in stage III, was switched back for two days to F080 for fear that he might die too soon (figure $3 \mathrm{c}$ ). This dog regained complete consciousness. When he received Freamine II again, the dog died after 10 days (figure $3 \mathrm{c}$ ).

All dogs initially receiving F080, regained complete consciousness within 24 hrs (stage $0-1$ ) and remained neurologically normal for 12 days (figure $3 a$ ). The infusion was then changed to Freamine II. Three dogs died comatose, one dog deteriorated to stage II only, remained in stage II for 8 days and was sacrificed (figure $3 a$ ). Thus, all dogs receiving the hepatic failure solution (F080) regained consciousness (stage $0-1$ ) and all dogs receiving the commercial solution (Freamine II) died in stage IV or remained encephalopathic.

Pre-infusion plasma amino acid levels and ratios (table 4, figure 4) At 1 week post-shunt, only minor changes were noted when compared to pre-shunt levels, except a significant increase $(p<.001)$ in phenylalanine. Plasma branched-chain amino acid (valine, leucine, isoleucine) levels decreased consistently at 1 week, but not statistically significant owing to the small number of animals. If branched-chain amino acid values were pooled

Table 5:

\section{Molar ratios}

Leucine + Isoleucine + Valine

Phenylalanine + Tyrosine

\begin{tabular}{lcccc}
\hline Dog number & Pre-shunt & 1 week & 4 weeks & Encephalopathy \\
\hline 1 & 4.14 & & 1.07 & 1.55 \\
2 & 4.09 & 1.96 & 1.17 & 1.32 \\
3 & 3.40 & 1.58 & 1.21 & 1.21 \\
4 & 3.62 & 1.29 & 1.06 & 1.36 \\
5 & 3.32 & & .94 & 1.19 \\
6 & 3.32 & 1.61 & 1.18 & 1.28 \\
7 & 4.74 & 1.49 & .74 & .74 \\
8 & 3.84 & 2.32 & .98 & 1.28 \\
$\bar{X}$ & $3.81^{*}$ & $1.71^{*}$ & $1.04^{*}$ & $1.24^{*}$ \\
S.E.M. \pm .18 & .15 & .06 & .08 \\
n & 8 & 6 & 8 & 8
\end{tabular}

*All differences significant at the $p<.01$ level at minimum

Table 5:

Leucine + Isoleucine + Valine molar ratios

Phenylalanine + Tyrosine

before porta-caval anastomosis, 1 week and 4 weeks after porta-caval anastomosis and in hepatic encephalopathy. 
from 1, 2 and 4 weeks (all dogs healthy and not in encephalopathy), highly significant decreases in plasma branched-chain amino acid levels were noted $(p<.001)$. Two weeks and 4 weeks post-shunt both plasma phenylalanine and tyrosine showed significant increases $(p<.001$ and $p<.01$ respectively) compared to pre-shunt values. Glutamate showed significant increases at 2 and 4 weeks $(p<.02)$, serine only when data from 2 and 4 weeks were pooled and compared with pre-shunt values. In severe encephalopathy (at least stage II-III) a generalized hyperaminoacidemia was noted with the exception of the branched-chain amino acids and lysine, which were similar to pre-shunt values and citrulline $(p<.01)$ and aspartate (not significantly) which decreased. All other amino acid concentrations increased (only alanine, glycine, threonine, proline and tryptophan: not significantly). When plasma amino acid levels at 4 weeks and in encephalopathy were compared, significant elevations were noted for alanine $(p<.05)$, serine $(p<.05)$ and methionine $(p<.05)$, and for leucine $(p<.01)$ and isoleucine $(p<.05)$. Valine showed the same trend, but statistical significance was not achieved. Hyperaminoacidemia tended to develop after 1 week and was most striking in encephalopathy. This would have been even more striking had glutamine been accurately measured. Glutamine levels pre-shunt and postshunt were at the upper level of the scale used during the amino acid analysis. In encephalopathy however, numbers were far off scale indicating increased levels which were not quantitated.

Molar ratios between the sum of the branched-chain amino acids and the sum of phenylalanine and tyrosine were calculated (table 5). A substantial drop was noted 1 week after shunt $(1.71 \pm .15)$, as compared to pre-shunt shunt ( $3.81 \pm .18$ ) which was even more pronounced after 4 weeks (1.04 \pm .06$)$. In encephalopathy however, ratios increased slightly $(1.24 \pm .08)$ compared with ratios at 4 weeks $(1.04 \pm .06)$.

Post-infusion amino acid levels and molar ratios.

Plasma amino acid levels are shown pre- and post-infusion (table 6). It was noted before (table 4) that plasma branched-chain amino acid levels in encephalopathy were not significantly different from the post absorptive state in normal non-shunted dogs. When F080 was infused in encephalopathic dogs branched-chain amino acid levels remained generally normal or were slightly increased. When Freamine II was infused however, plasma branched-chain amino acid levels dropped significantly (only isoleucine levels were not significantly depressed). Plasma phenylalanine levels dropped significantly when F080 was infused and rose again when Freamine ll was infused. Plasma tyrosine levels dropped to below normal when F080 was infused. With Freamine II, tyrosine levels increased but did not reach the levels that were observed in encephalopathy before infusion. When molar ratios between the sum of the branched-chain amino acids and the sum of the aromatic amino acids were calculated, a "normal" ratio of 3.85 was reached with F080, corresponding with a normal mental state. When Freamine II was infused however, the ratio decreased (1.26) corresponding with encephalopathy. The one dog that survived the initial period with Freamine II, albeit with encephalopathy grade II, exhibited a ratio of 0.96 , 


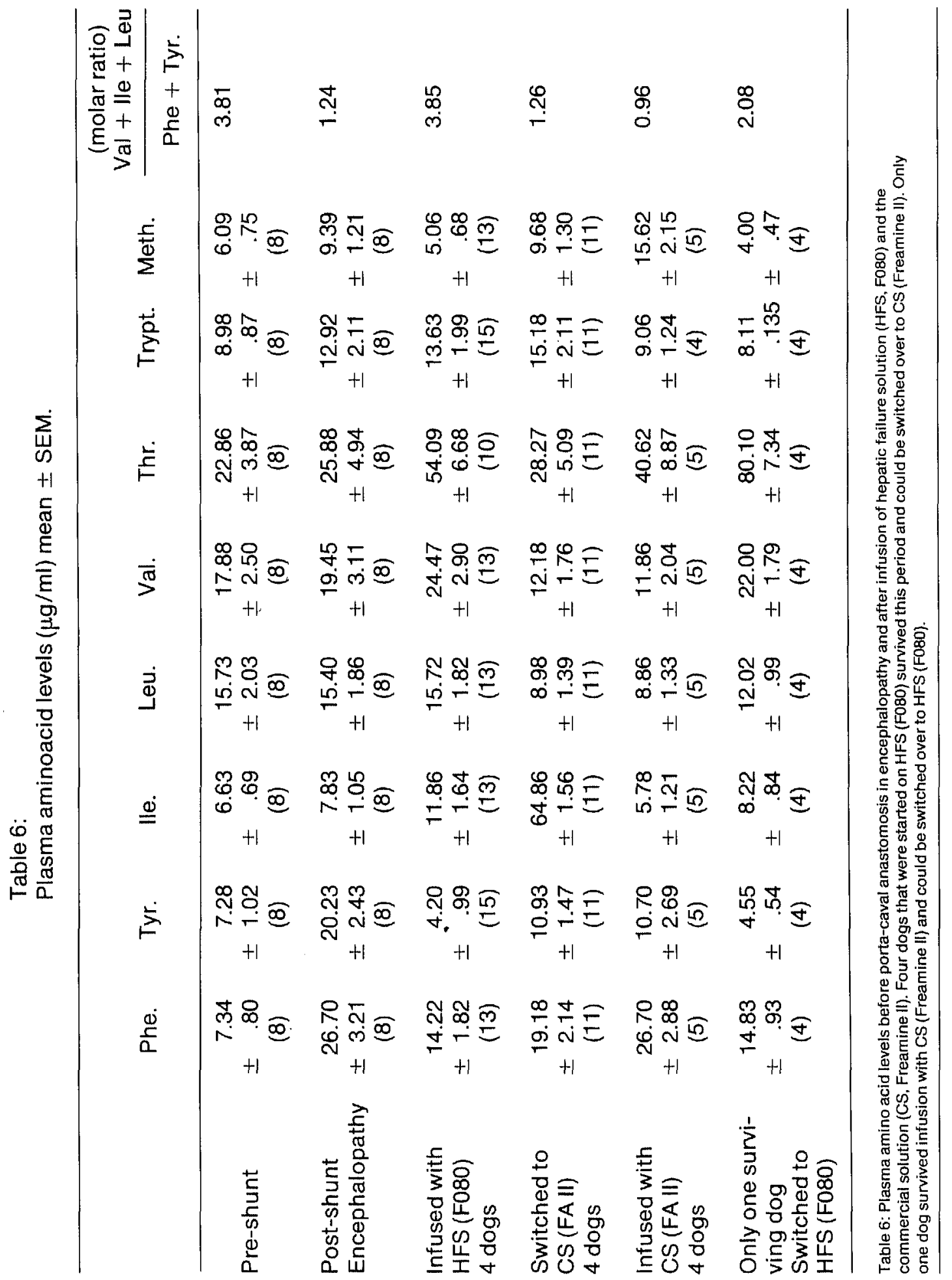


which increased to 2.98 when F080 was infused, corresponding with a normal mental state. Methionine levels changed parallel to phenylalanine and tyrosine; threonine displayed a pattern which was similar to the branchedchain amino acid pattern.

\section{Routine laboratory data}

Plasma alkaline phosphatase was increased after shunt especially after 1 week and in hepatic encephalopathy (figure 5). This increase was even more pronounced after infusion of either type of solution. Plasma SGOT levels equally increased after porta-caval shunt. This increase was most pronounced in hepatic encephalopathy. No consistent changes were noted after infusion (figure 6). Plasma LDH levels were especially increased 1 week after shunt (figure 7). No consistent LDH pattern was noted, except a tendency to rise when the dogs who received F080 initially were switched over to Freamine II. Unfortunately, plasma SGPT and subfractions of LDH were not determined. Plasma albumin levels were slightly but significantly decreased in encephalopathy as compared to pre-shunt levels (figure 8 ). This decrease was not affected by parenteral feeding. Globulin levels were not affected (figure 9). Cholesterol levels decreased in most dogs after porta-caval shunts (figure 10). This phenomenon was clearly enhanced after parenteral feeding. Triglyceride levels decreased after porta-caval shunt (figure 11) but less so in encephalopathy. No clear additional changes were observed after infusion. Free fatty acid levels were especially elevated in encephalopathy (figure 12). A decrease was observed with parenteral nutrition. Creatinine and BUN levels were significantly decreased 1,2 and 3 weeks after shunt (figures $13,14)$ and less significantly in encephalopathy. Infusion did not induce major changes. No renal insufficiency was noted at any time. Serum ammonia rose significantly after porta-caval shunt, and was most pronounced in encephalopathy (figure 15). Ammonia levels dropped dramatically after initiation of parenteral nutrition in either group. Prothrombin times did not show major changes. Hct dropped slightly after porta-caval shunt. Significant decreases were noted after initiation of therapy (figure 16).

Body weights and nitrogen balances.

Body weights decreased slightly after shunt (pre-shunt $20.45 \mathrm{~kg} \pm$ SEM 0.6) 2 weeks after shunt $19.53 \mathrm{~kg} \pm .75 ; 3$ weeks after shunt $19.69 \mathrm{~kg} \pm 1.05)$.

Significant loss of body weight occurred in encephalopathy $(16.27 \mathrm{~kg} \pm 1.15)$. At this time, negative nitrogen balances were noted of $7-10 \mathrm{~g} \mathrm{~N} /$ day. Positive nitrogen balances were achieved with both solutions (Freamine $\|+1.16 \mathrm{~g}$ $\mathrm{N} /$ day; F080 + $3.85 \mathrm{~g} \mathrm{~N} /$ day).

Histology.

Histologic findings at autopsy were characterized by marked atrophy of hepatocytes. No signs of liver-cell necrosis were observed. 

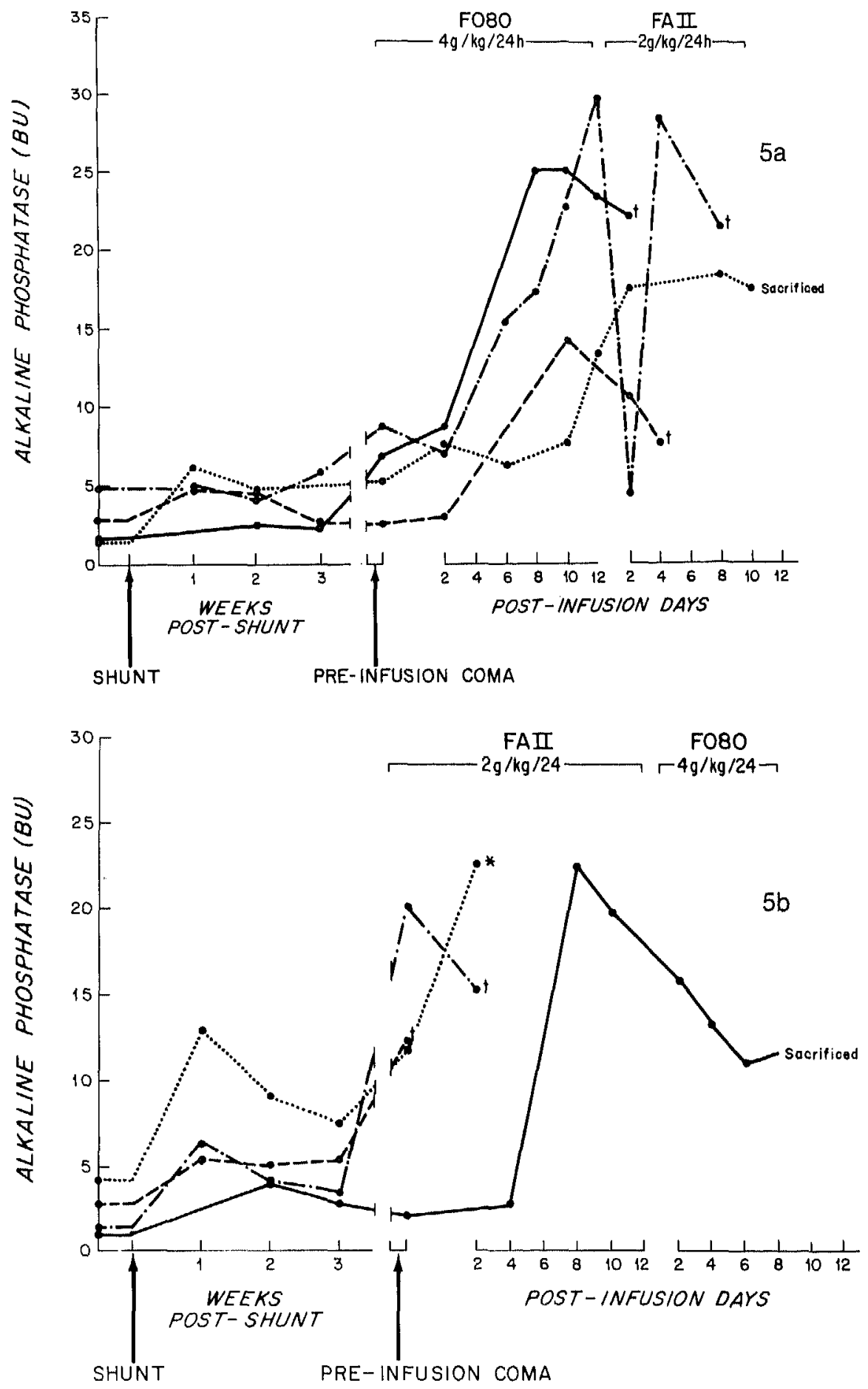

Figure 5 a + b: Plasma alkaline phosphatase levels, preshunt, 1,2, and 3 weeks after shunt, in encephalopathy and after intravenous therapy. 

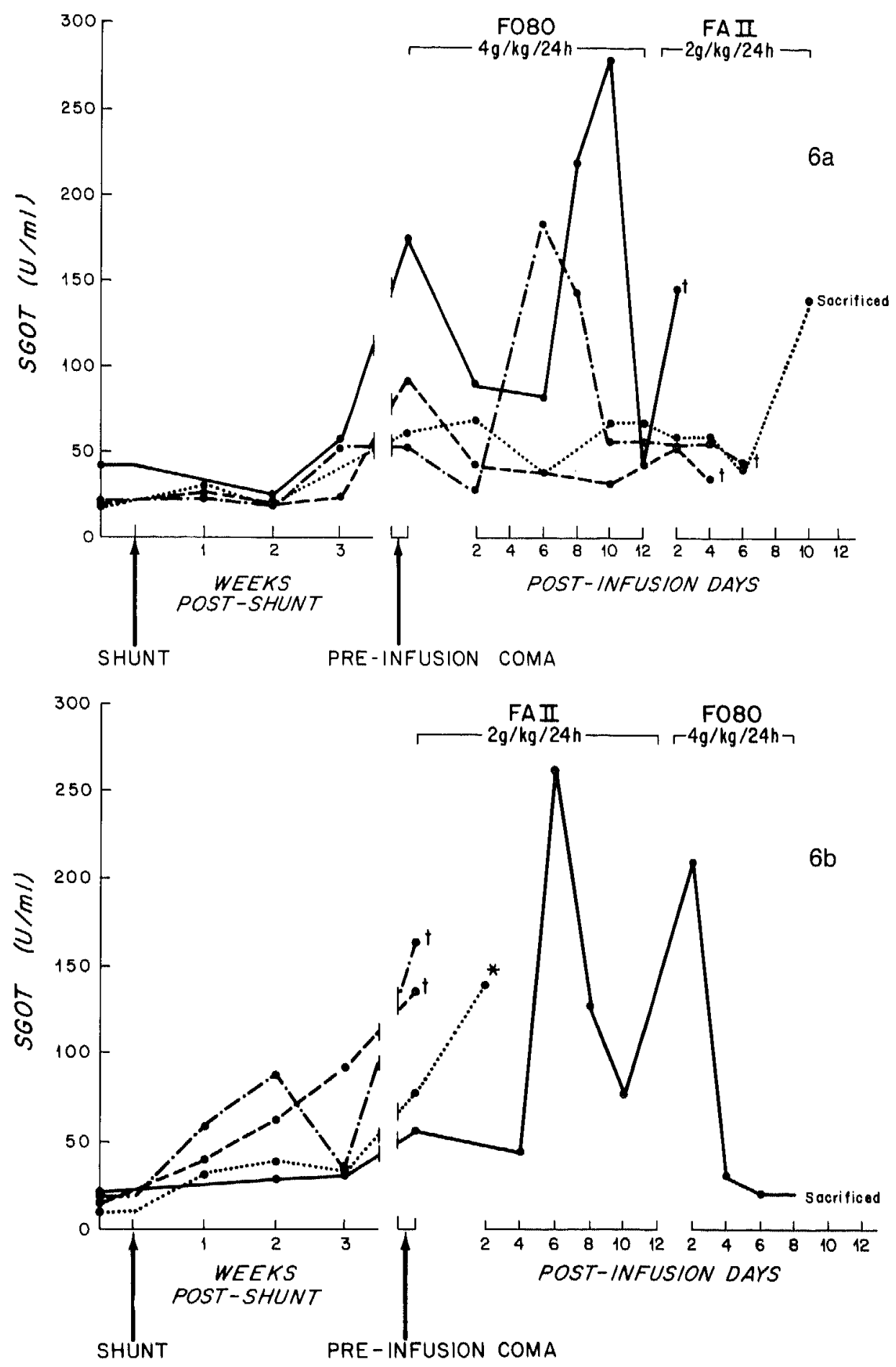

Figure 6 a + b: Plasma SGOT levels, preshunt, 1,2, and 3 weeks after shunt, in encephalopathy and after intravenous therapy. 

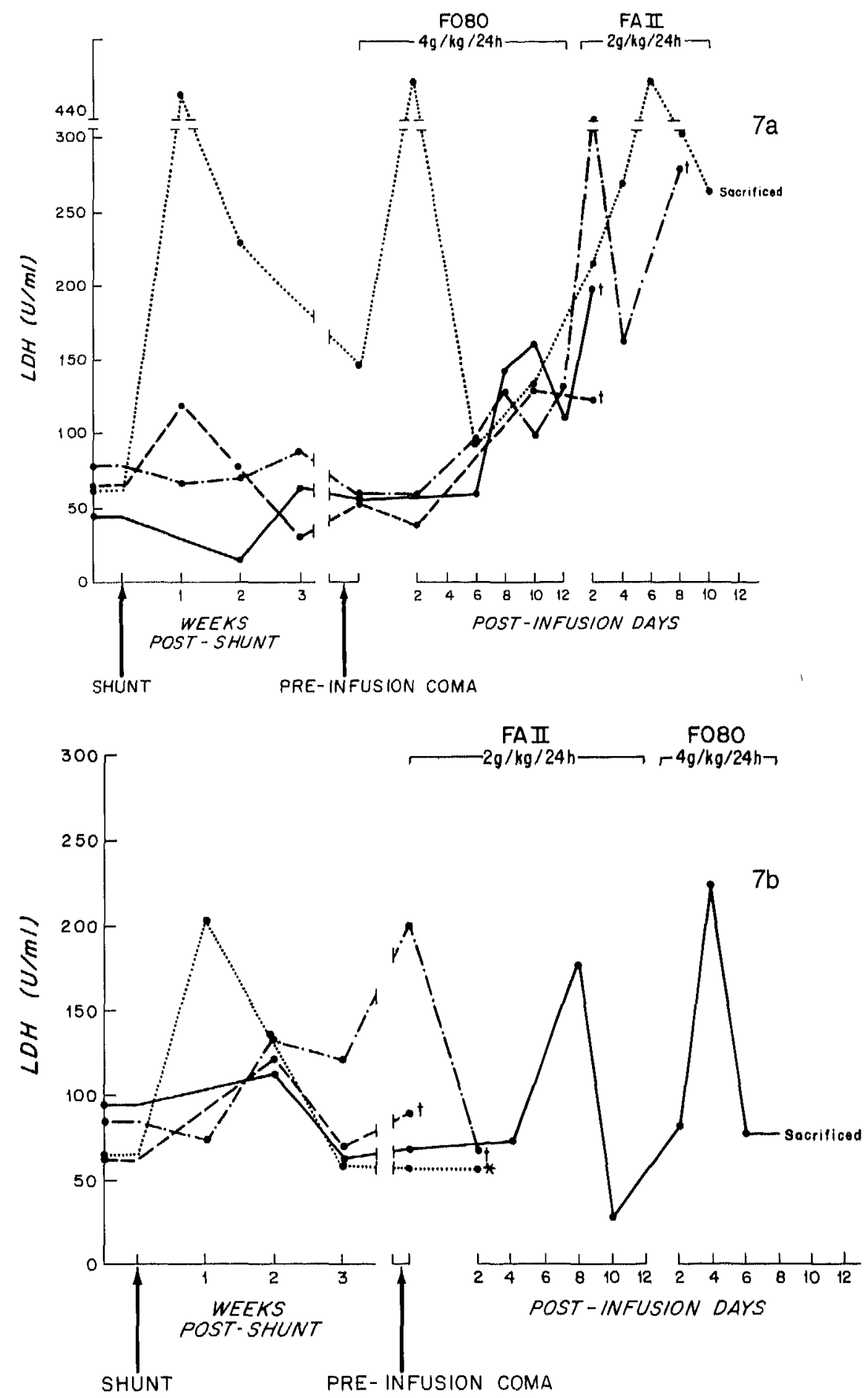

Figure $7 \mathrm{a}+\mathrm{b}$ : Plasma LDH levels preshunt, 1,2, and 3 weeks after shunt, in encephalopathy and after intravenous therapy. 


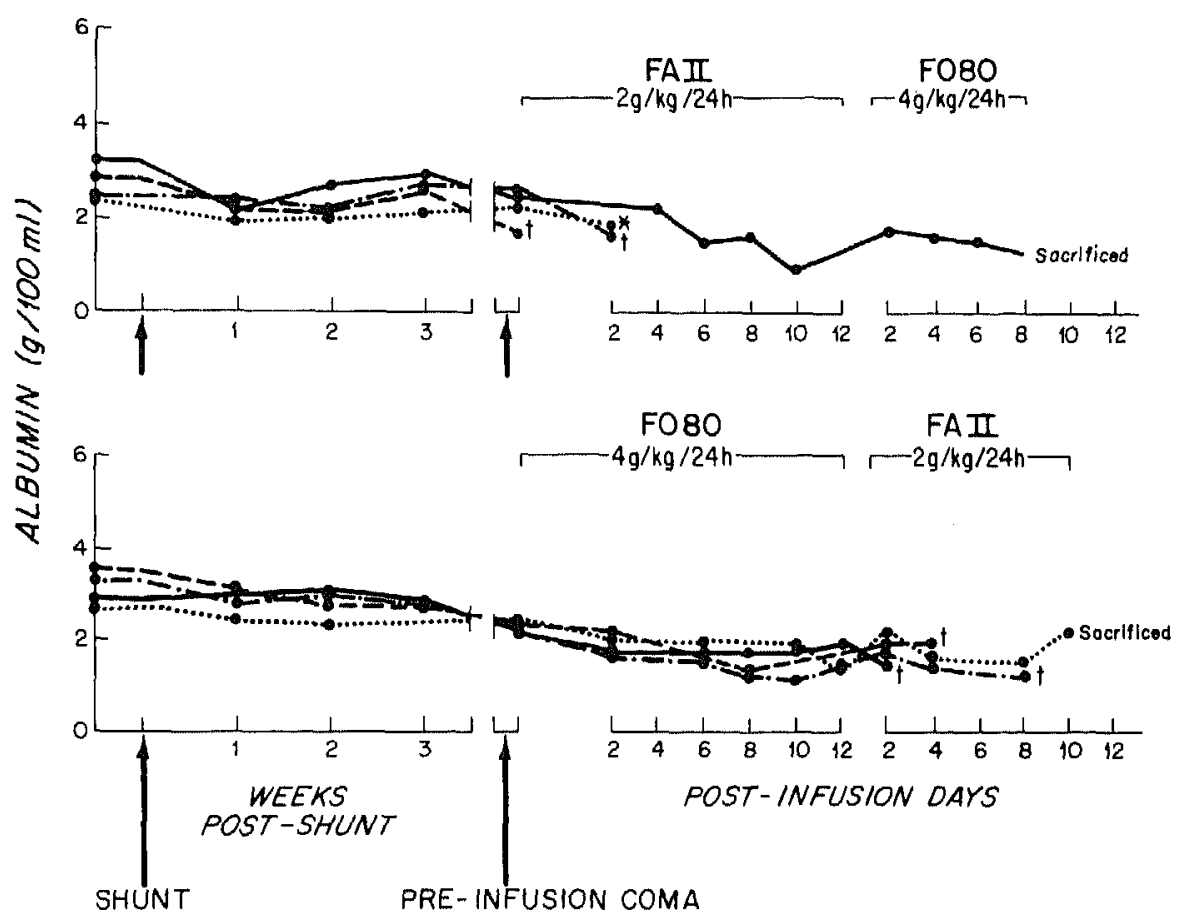

Figure 8: Plasma albumin levels, preshunt, 1,2, and 3 weeks after shunt, in encephalopathy and after intravenous therapy.

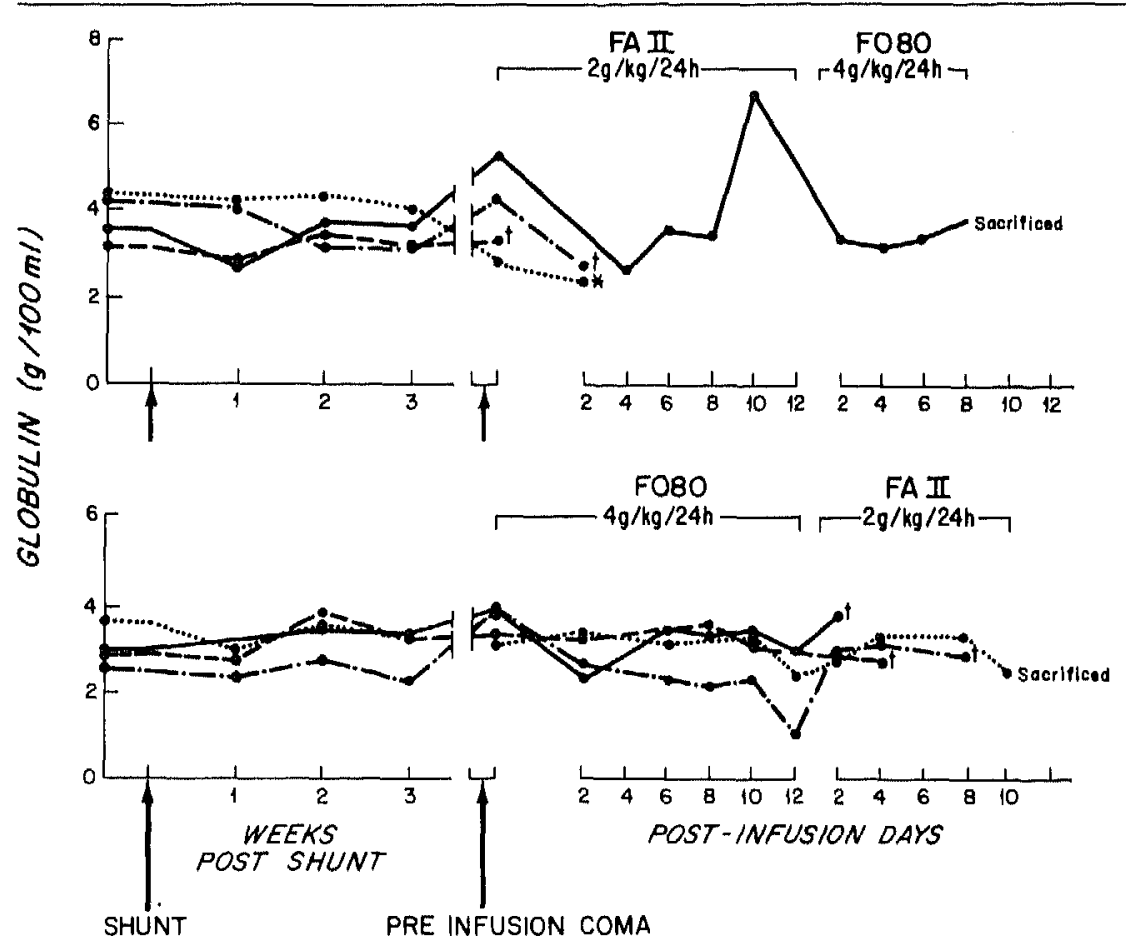

Figure 9: Plasma globulin levels, preshunt, 1,2, and 3 weeks after shunt, in encephalopathy and after intravenous therapy. 

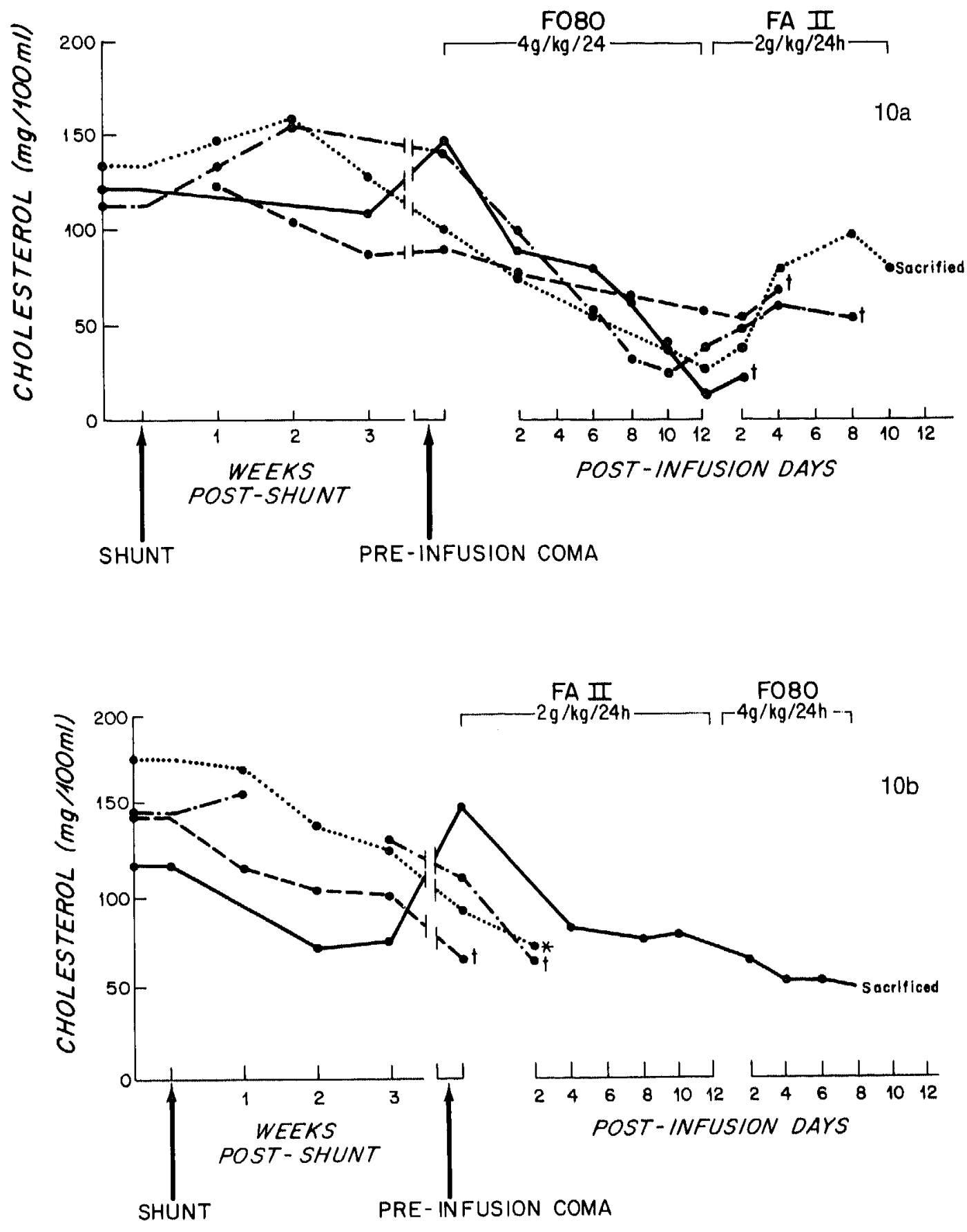

Figure $10 \mathrm{a}+\mathrm{b}$ : Plasma cholesterol levels, preshunt, 1,2, and 3 weeks after shunt, in encephalopathy and after intravenous therapy. 


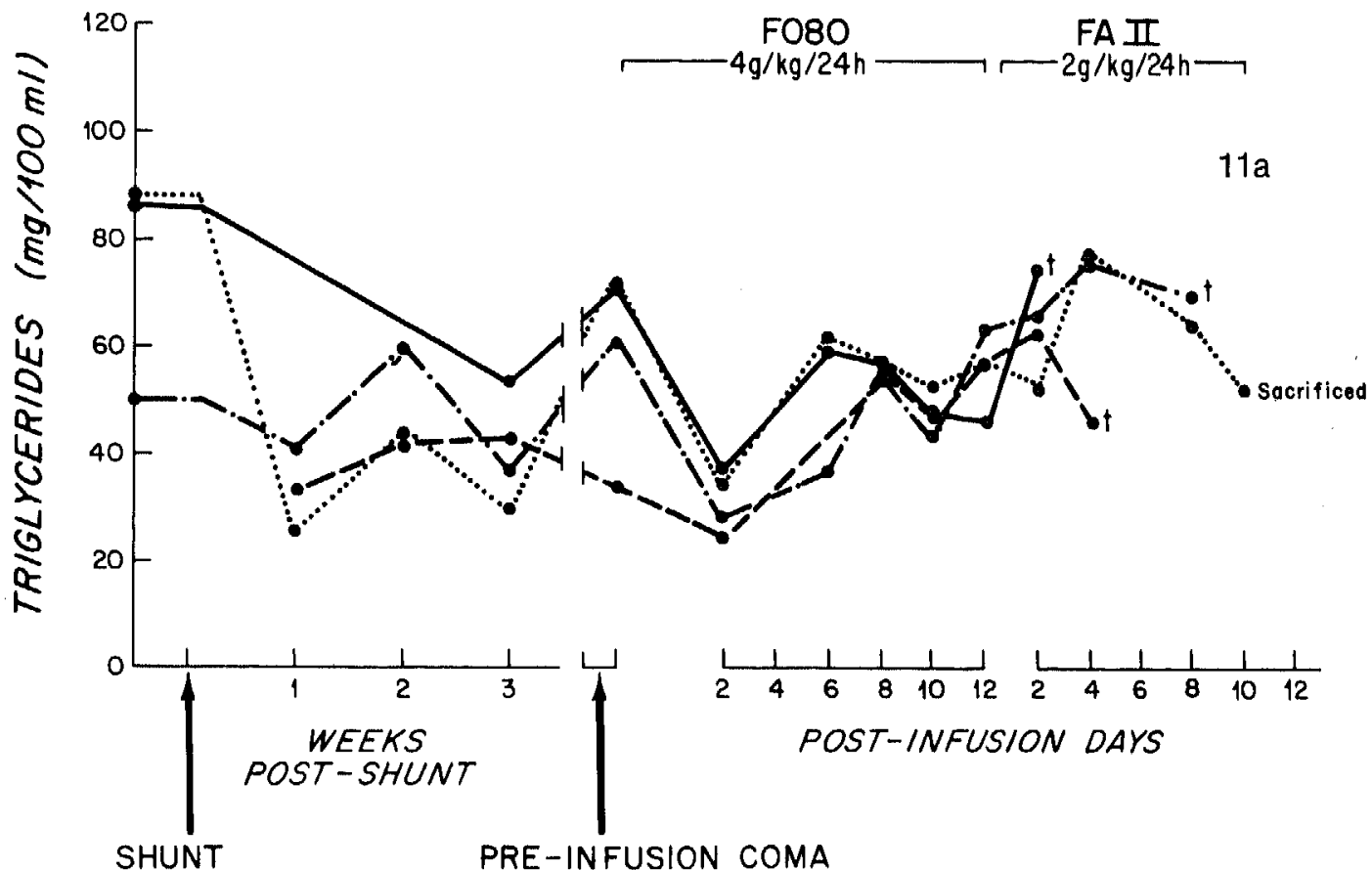

PRE-INFUSION COMA

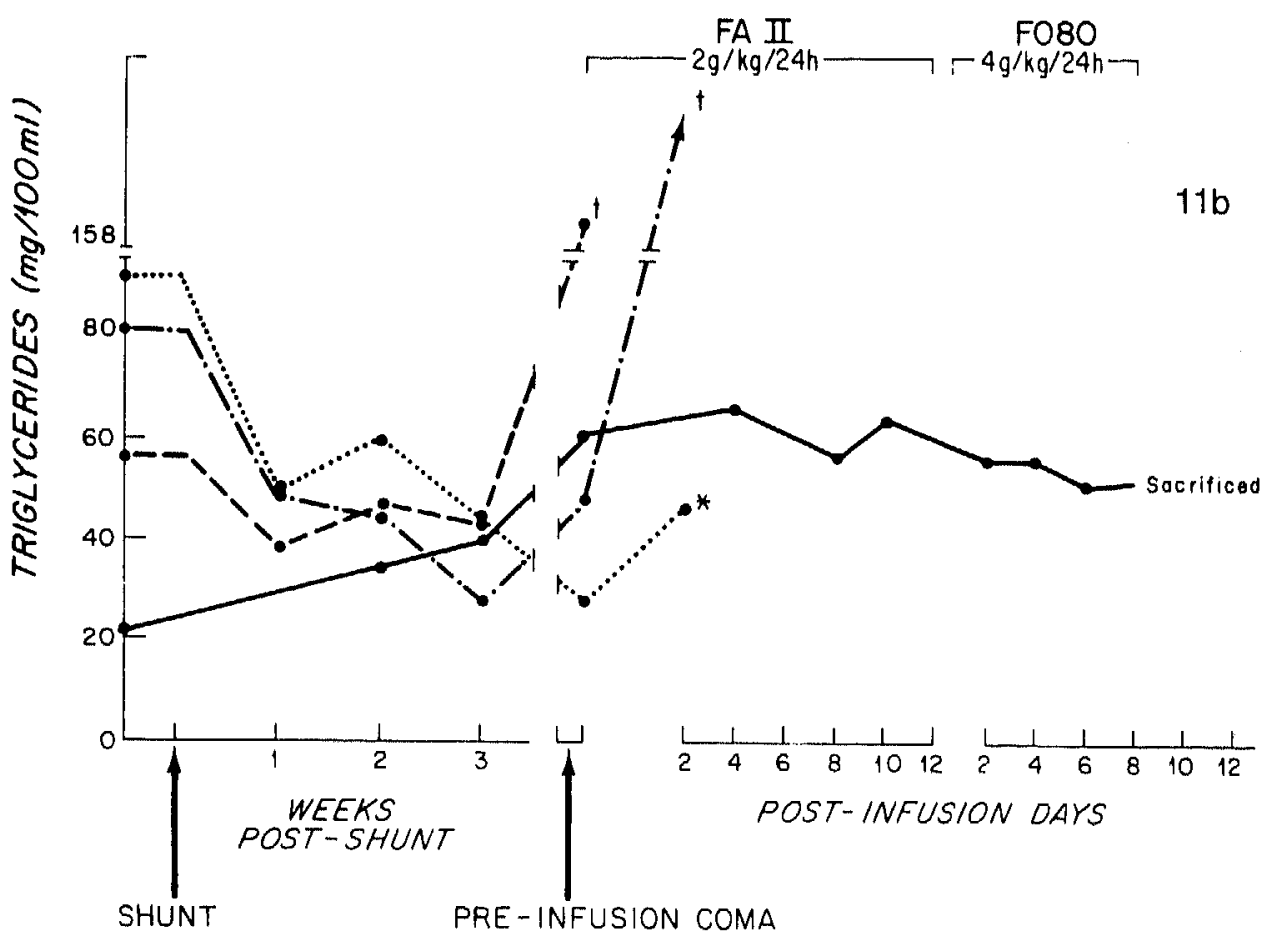

Figure $11 \mathrm{a}+\mathrm{b}$ : Plasma triglyceride levels, preshunt, 1,2, and 3 weeks after shunt, in encephalopathy and after intravenous therapy. 


\subsection{Discussion}

Dogs with porta-caval shunts have been widely employed as model for liver failure and hepatic encephalopathy. Porta-caval anastomosis in most species eventually induces liver failure, encephalopathy and death provided that no young, unmature animals are used. This equally applies to man. It is possible that regenerative capacity at a younger age safeguards hepatic function. Biopsy specimens of the liver show atrophy rather than necrosis. The inevitable deteriorations of liver function observed in older animals with porta-caval shunts however suggest that the model used, produces a coma which is of an endogenous nature. The slow deterioration of hepatic function allows the study of exogenous factors. The purpose of this study was mainly to study the effect on encephalopathy of a specific amino acid glucose solution, roughly calculated to normalize the plasma amino acid

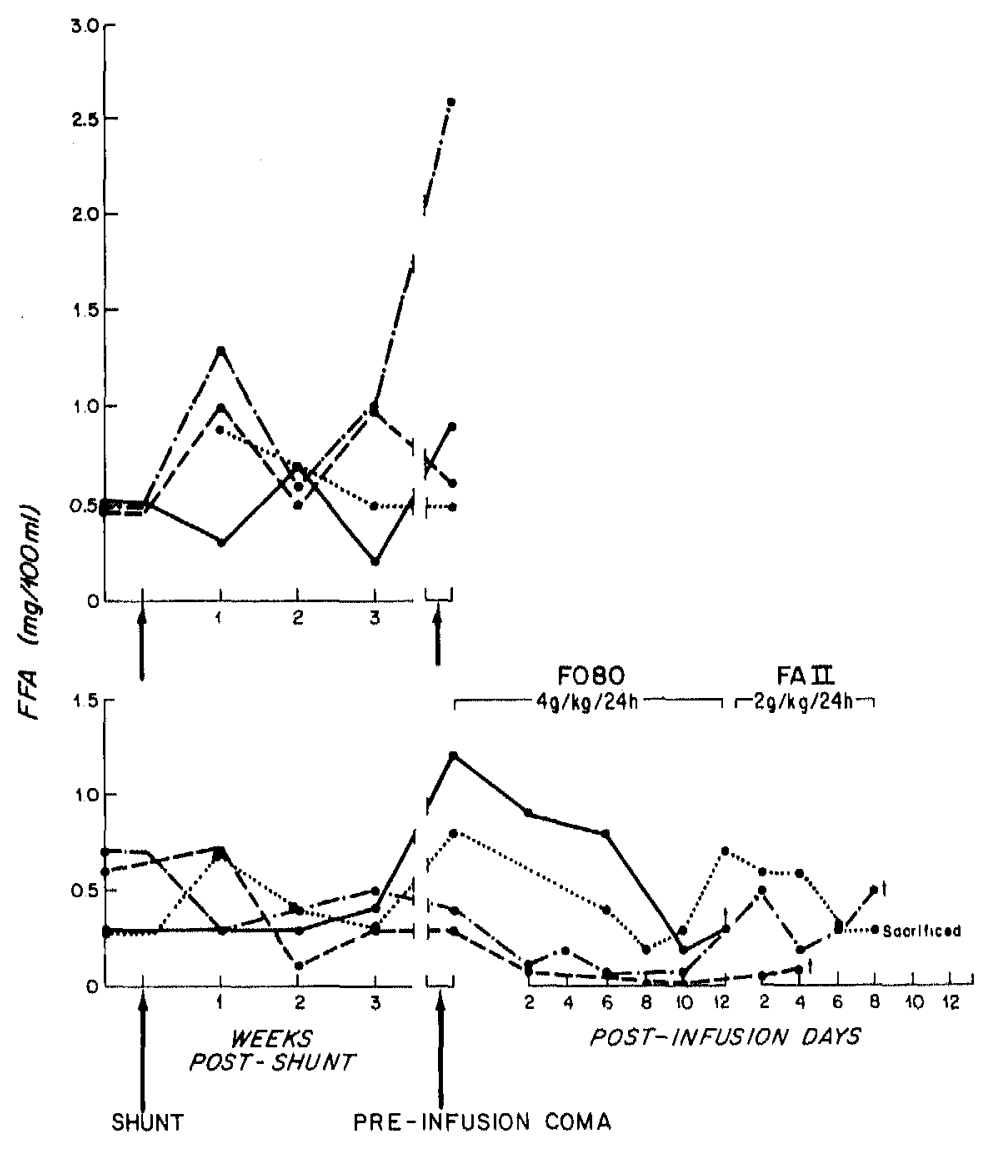


pattern encountered in hepatic encephalopathy, in a randomized cross-over fashion in dogs with porta-caval shunts. Essentially, each dog served as its own control. The controls received the equivalent of standard therapy in patients, consisting of hypertonic glucose and a reduced dose of amino acids. This study was not designed to specifically study neurotransmitter metabolism. The results herein reported show clearly that F080 enables us to feed dogs with hepatic encephalopathy with supranormal amounts of amino acids, at the same time achieving improvement in neurological state, and that this solution is far superior to one half the dose of a conventional solution and hypertonic glucose.

In earlier reports (53) much importance was attached to the ratio between the sum of the plasma branched-chain amino acids and the sum of the amino acids tyrosine and phenylalanine. It was suggested that this ratio might be an indicator for encephalopathy. Our data show that this ratio is without exception decreased in encephalopathy, but does not distinguish between encephalopathy and normal mental state at 4 weeks.

However, this ratio does not take into account free tryptophan, which rises precipitously in animals $(37,52,53)$ and patients $(54)$ developing hepatic encephalopathy. Branched-chain amino acid levels were decreased 1,2 , and 4 weeks post-shunt, but normal in encephalopathy, suggesting that contrary

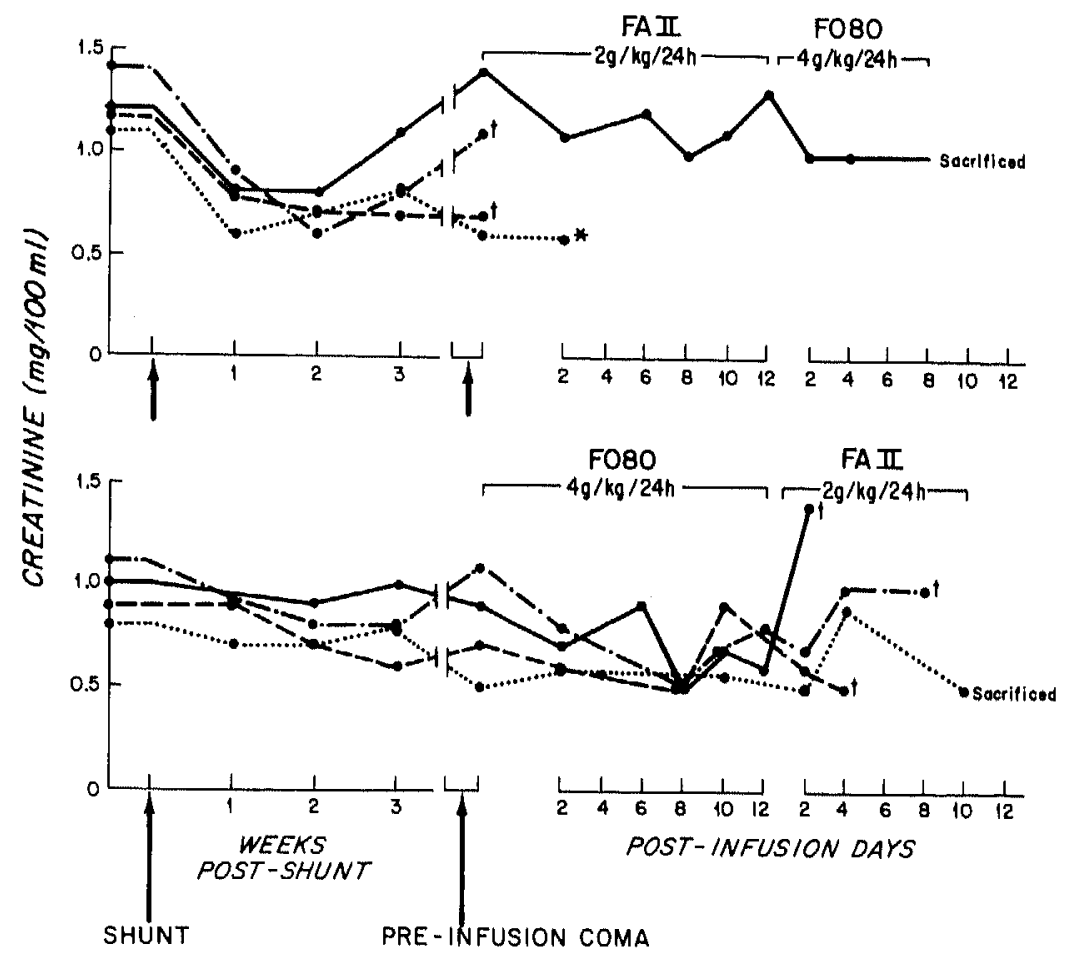

Figure 13: Plasma creatinine levels preshunt, 1,2, and 3 weeks after shunt, in encephalopathy and after intravenous therapy. 

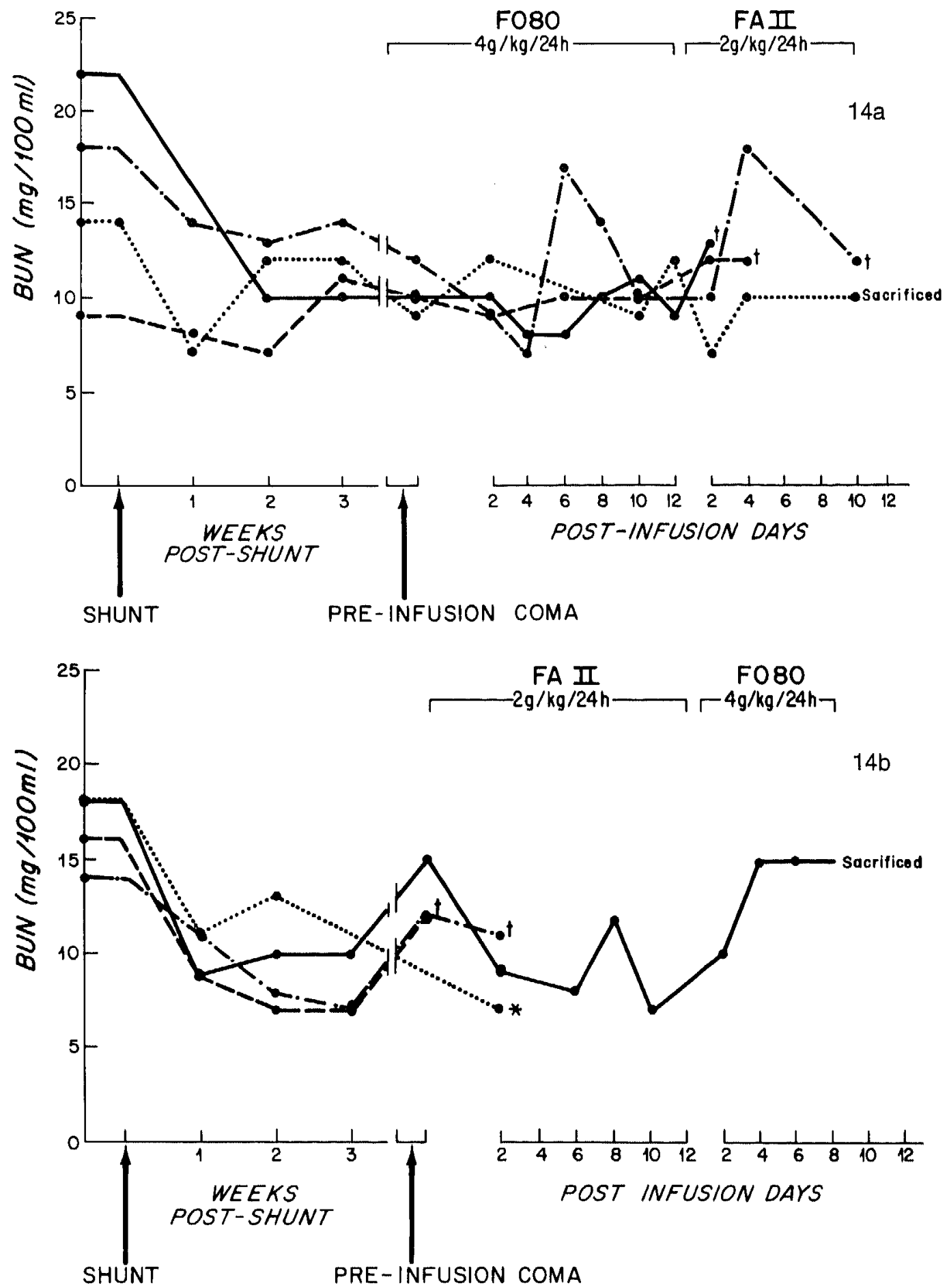

Figure $14 \mathrm{a}+\mathrm{b}$ : Plasma BUN levels, preshunt, 1,2, and 3 weeks after shunt, in encephalopathy and after intravenous therapy. 

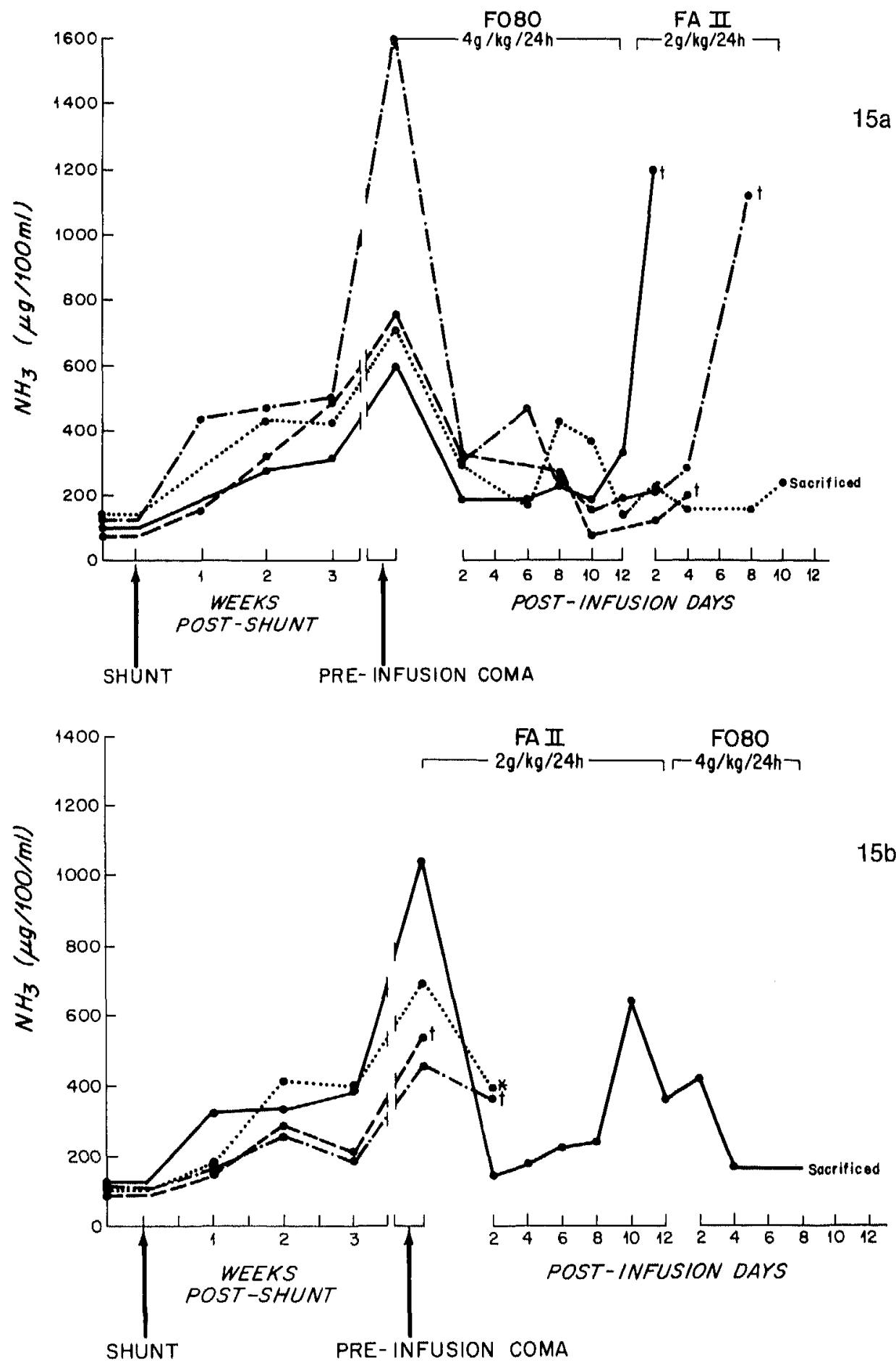

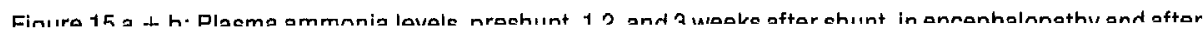


to what was claimed before, no decrease has to be present to allow greater quantities of aromatic amino acids to enter the brain. This is in agreement with findings in rats which showed that transport of all neutral amino acids is enhanced into the brain after porta-caval shunt, according to their levels in plasma (56). These findings are in accordance with those of Record a.o. (57) in patients with fulminant hepatitis showing that when plasma branchedchain amino acid levels were low, patients generally survived; when elevated however, patients could be expected to die. In encephalopathy, generalized hyperaminoacidemia was noted which is in agreement with hyperaminoacidemia noted in starvation $(58,59)$. These dogs were all starved by the time they were encephalopathic losing appetite spontaneously. They could not adapt to starvation however exhibiting rapid weight losses and high nitrogen losses. A catabolic state results in hyperaminoacidemia. High glutamine levels apparently resulted from peripheral protein breakdown and the relative inability of the liver to convert glutamine to urea and glucose. This catabolic state results in increases of plasma glutamine, alanine, methionine, tyrosine and phenylalanine, because they are broken down peripherally (branchedchain amino acids) (60) or transformed peripherally (non-essentials) into glutamine or alanine $(61,62)$.

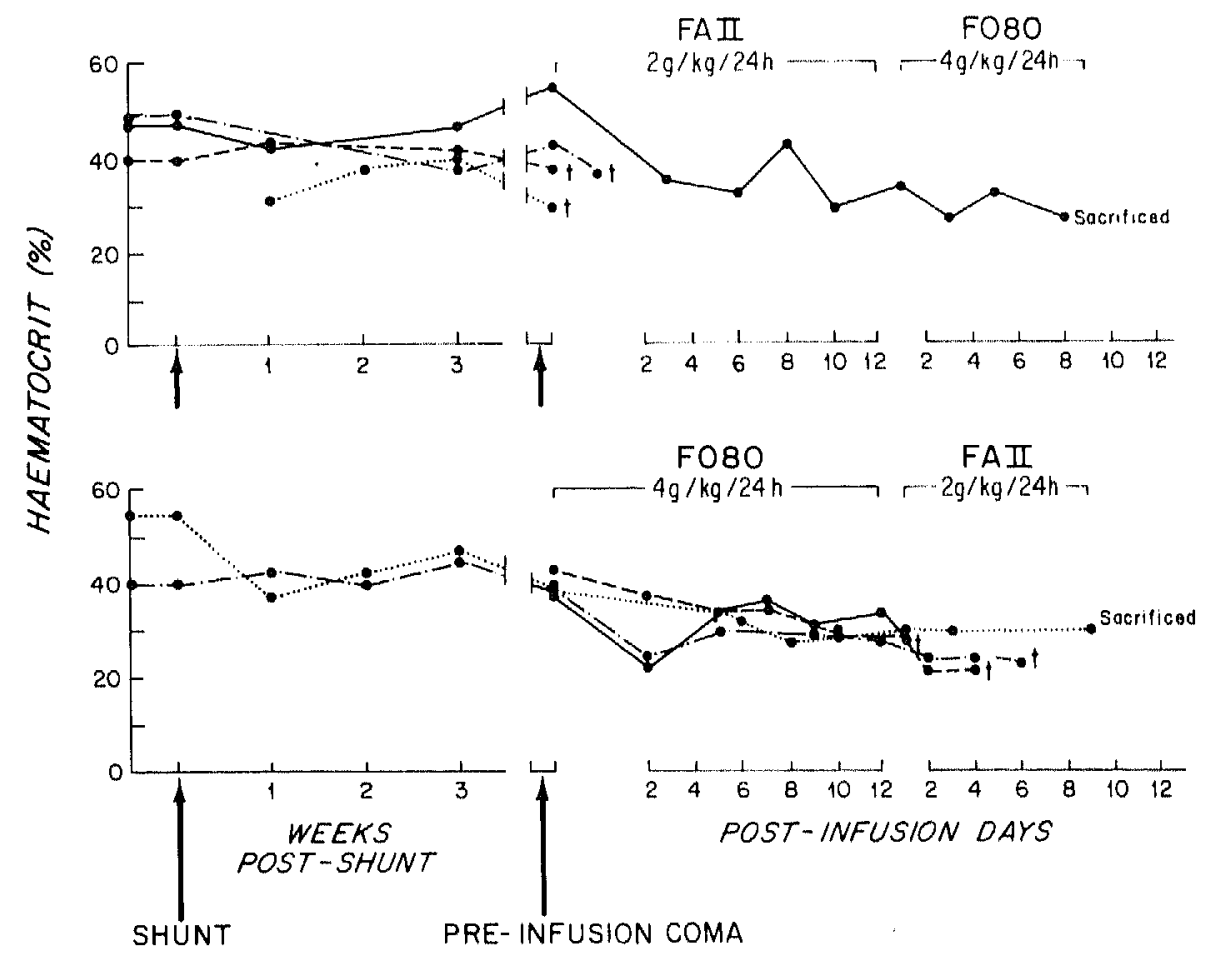

Figure 16: Plasma haematocrit levels, preshunt, 1,2, and 3 weeks after shunt, in encephalopathy and after intravenous therapy. 
Amino acid levels in encephalopathy differed significantly when compared with 4 weeks only for leucine, isoleucine, methionine, alanine and serine. Glutamine would likely have shown a dramatic increase if it could have been quantitated. Citrulline showed a significant decrease between 4 weeks and encephalopathy. We do not know the contribution of the low plasma concentrations of this urea cycle intermediate to hyperaminoacidemia. Feeding restores anabolism resulting in positive nitrogen balance $(+3.85 \mathrm{~g}$ $\mathrm{N} /$ day F080 $+1.16 \mathrm{~g} \mathrm{~N} /$ day Freamine II), channelling $\alpha$ amino nitrogen back into protein synthesis, in this way decreasing hyperaminoacidemia. Conventional amino acid mixtures however, sustain a disequilibrium in amino acids because they also add to a surplus of methionine and phenylalanine. The specific formula from F080 composition does not add additional aromatic amino acids allowing the surplus of "bad" amino acids to be taken up into protein synthesis and presenting the liver with smaller amounts of tyrosine and phenylalanine, for which the liver has only a limited capacity to catabolize. This results in normalization of neutral amino acid ratios and conjecturally normalization of the pattern of uptake into the brain. Tryptophan levels which may equally play an important role in encephalopathy were normal or slightly increased. An important determinant of tryptophan transport into the brain however is free tryptophan (47), which rises, increasing brain serotonin (inhibitory) and possibly contributing to hepatic encephalopathy. Plasma creatinine and BUN decreased immediately after shunt ( 1 week), indicating probably that clearance rate increased, due to the well known phenomenon of increased cardiac output after porta-caval shunt in experimental animals. Other explanations seem unlikely as a decrease in muscle mass would at least temporarily have been reflected in increased urea levels. Nor does an increased urinary ammonia excretion affect plasma creatinine levels. Renal function was never impaired. This is inherent to the model used i.e. porta-caval shunting without portal hypertension, ascites, edema etc..

Liver function parameters (alkaline phosphatase, LDH, SGOT) deteriorated with time and were generally not corrected by parenteral feeding. This was also noted with regard to albumin levels who decreased further despite the administration of glucose amino acid mixtures.

The data suggest that this decrease occurs parallel to decreases in haematocrit (figures 8 and 16). This may be a dilutional phenomenon, which is common in hepatic failure (87). No clinical signs of overhydration were observed, nor were there signs of major pulmonary edema at autopsy. Some dogs never developed encephalopathy and hepatic failure. These dogs were without exception young dogs ( \pm 1 year). This is in agreement with the finding that children or young adults do seem to tolerate porta-caval shunt performed for other reasons than portal hypertension (i.e. glycogen storage disease $(64,65)$, homozygous familial hypercholesterolaemia $(64,66,67,68)$ reasonably well. Plasma cholesterol levels showed the same decrease after porta-caval shunt that is described and studied in the literature $(69,70,71)$ and that has led some to treat some inborn errors of metabolism with portacaval shunt $(64,65,66,67,68)$. The exact mechanism is still moot $(72)$.

Ammonia levels increased significantly at all times after porta-caval shunt but 
most significantly so in encephalopathy. Levels of $803 \pm 129.5 \mu \mathrm{g} / 100 \mathrm{ml}$ (SEM) were observed in encephalopathy. This is in contradistinction with earlier reports (53). Only dogs in severe encephalopathy were accepted in this study however. Very significant decreases of ammonia levels were observed with either type of solution. The underlying mechanism is not clear. It is unlikely that withdrawal of oral intake may have curtailed ammonia production in the gut, because these dogs stopped eating spontaneously long before being hyperalimented.

\subsection{Summary}

Eight dogs developed hepatic encephalopathy 5 weeks to 6 months after receiving a porta-caval shunt. They were infused in a randomized cross-over fashion with a glucose - amino acid mixture ( $4 \mathrm{~g}$ amino acids $/ \mathrm{kg} / 24 \mathrm{hrs}$ ) of a specific amino acid composition calculated to normalize the pathological plasma amino acid pattern, encountered in hepatic encephalopathy, or a glucose amino acid mixture with a reduced amino acid content $(2 \mathrm{~g}$ amino acids $/ \mathrm{kg} / 24 \mathrm{hrs}$ ) of a conventional composition.

1. It was shown that these dogs could be fed with the specific glucose amino acid mixture at the same time achieving improvement in neurological state, and that this could not be achieved with one half the dose of a conventional solution and hypertonic glucose.

2. The ratio between the sum of the branched-chain amino acids and the sum of the aromatic amino acids decreased significantly after porta-caval shunt but no further decrease was observed in hepatic encephalopathy, so that in these experiments this ratio was no sensitive indicator for hepatic encephalopathy.

3. Infusion for F080 achieved besides improvement in neurological state, significant reductions in plasma tyrosine- and -phenylalanine concentrations, resulting in a normal $\frac{\text { valine }+ \text { isoleucine + leucine }}{\text { tyrosine }+ \text { phenylalanine }}$ ratio.

This could not be achieved with Freamine II.

4. A reduction in plasma ammonia levels was achieved after infusion of either type of solution.

5. The conclusion is warranted that adding branched-chain amino acids to, and withdrawing aromatic amino acids from conventional solutions is crucial for the achievement of a beneficial effect on neurological status, at the same time allowing the administration of sufficient amounts of nitrogen. This suggests that the pathologic plasma amino acid pattern observed in hepatic encephalopathy may be related to hepatic encephalopathy. 


\section{Chapter 3}

Insulin, glucagon, portal systemic shunting and hepatic failure in the dog.

\subsection{Introduction}

The distorted plasma amino acid pattern in hepatic failure and hepatic encephalopathy is common throughout the animal kingdom, including the rat $(28)$, the dog $(34,53,73)$, and man $(36,37,74)$.

In recent years, interest has focused on the causation of these changes in plasma amino acid pattern. Sherwin et al. (75) and Munro et al. (76) have suggested that the decreased branched-chain amino acids so prominent in the plasma amino acid pattern are secondary to hyperinsulinism present in animals or patients with liver disease and following portal systemic shunt. Sherwin et al. (75) also proposed that the hyperglucagonemia found in patients with alcoholic cirrhosis may also contribute to the glucose intolerance (75) frequently observed in hepatic disease, very much as it is manifest in infection and burns $(77,78)$.

More recently, results from this and other laboratories have suggested that the modification of the deranged plasma amino acid pattern after either infusion (53) or perfusion techniques $(79,80)$ may result in the amelioration of hepatic encephalopathy. Insulin and glucagon are both intimately related to amino acid metabolism. The present experiments were undertaken to study the influence of both portal systemic shunting and hepatic function on plasma insulin and-glucagon levels as well as on amino acids in an attempt to determine the relative importance of shunting and hepatic function on these various parameters.

\subsection{Methods}

Surgical techniques and extensive monitoring occurred as previously described (chapter 2).

Blood samples for radioimmunoassay were drawn early in the morning before feeding. Arginine infusion tests were performed before operation, 1 week and 4 weeks after operation, and when the animal became encephalopatic. Arginine is an amino acid with a powerful stimulating action on glucagon secretion and is commonly used to assess pancreatic $\beta$ cell function. During the experiment, the animal was lightly anaesthetized with Surital. After two basal blood samples were drawn, $0.45 \mathrm{~g}$ of arginine hydrochloride $/ \mathrm{kg}$ body weight was infused in a period of 10 minutes in normal saline. Blood samples were drawn at the end of the infusion and after 10,30 and 50 minutes, and were analyzed for immunoreactive insulin, immunoreactive glucagon, and plasma glucose. Blood was collected in chilled heparinized glasstubes containing 0.2 of Trasylol.

Plasma glucose concentrations were determined with a Beckman glucose analyzer, model ERA 2001 (Beckman Instruments Inc., Fullerton, California). Plasma immunoreactive glucagon was determined by radioimmunoassay 
(73) using antiserum $30 \mathrm{~K}$ kindly provided by $\mathrm{Dr}$. Roger $\mathrm{H}$. Unger of Dallas, Texas. Pork glucagon standard (Lot GLF 599 A) was provided by the Eli Lilly Company, Indianapolis, Indiana). Total immunoreactive glucagon was measured and therefore includes the immunoreactivity contributed by moieties with molecular weights of $160.000,9.000$, and 3.500 daltons $(81,82)$. Plasma immunoreactive insulin was determined by radioimmunoassay (83) and human insulin was used as a standard (Lot 258-10643-27, Eli Lilly Company, Indianapolis, Indiana). As animals matured after shunt, they generally developed encephalopathy 5 weeks -6 months after end-to-side porta-caval shunt. Stages of encephalopathy were assessed clinically according to a scheme previously suggested (chapter 2). Arginine infusion tests were performed in stages II - III.

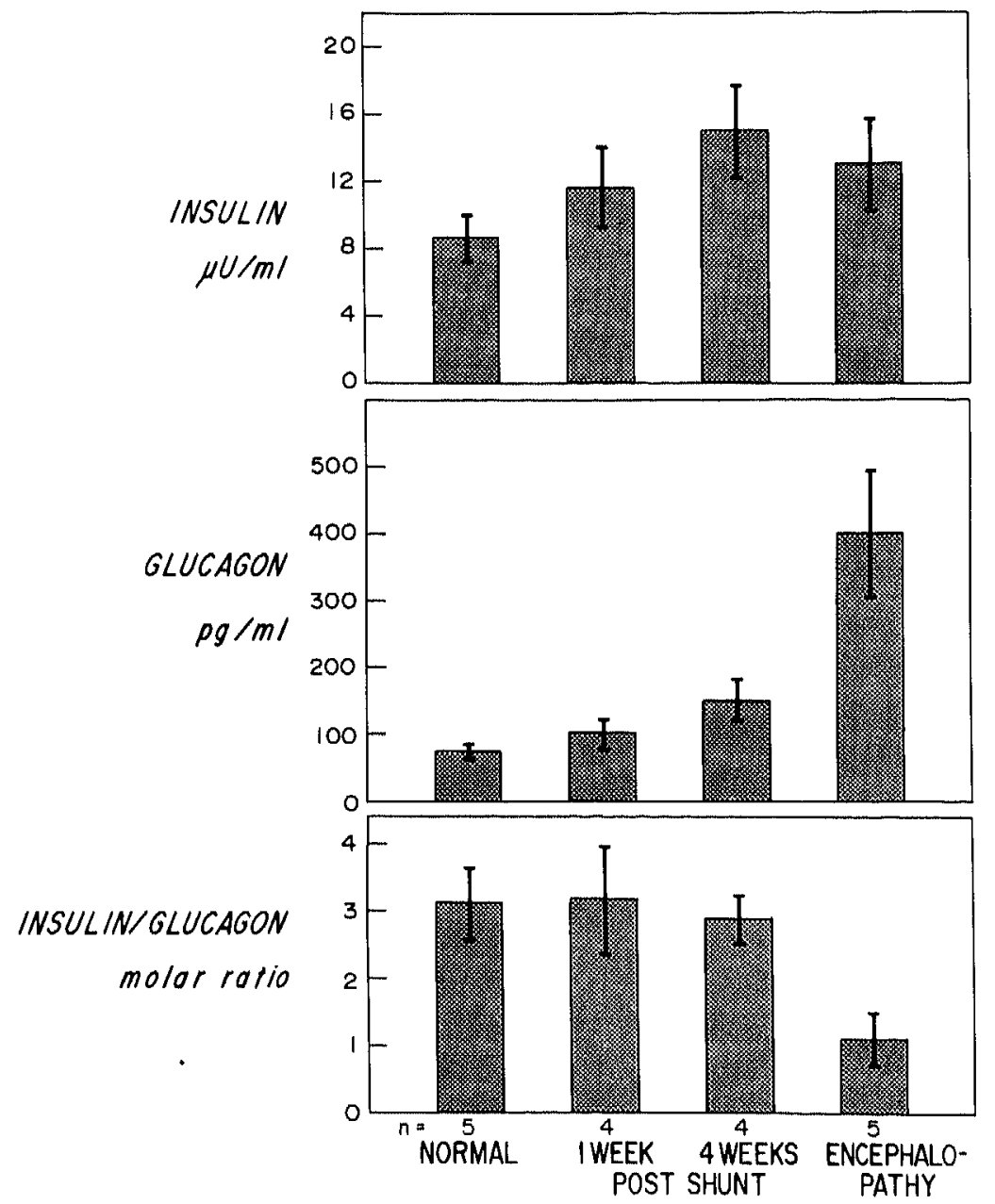

Figure 17: Serial measurement of insulin and glucagon following end-to-side porta-caval shunt and in encephalopathy. Results are given as mean \pm SEM for groups of 5 animals. Note that there is a modest rise in both insulin and glucagon after introduction of the end-to-side porta-caval shunt. As the animal develops hepatic failure and encephalopathy, glucagon rises precipltously. 


\subsection{Results}

Dogs remained reasonably normal neurologically for 5 weeks to 6 months post-shunt, although gradual weight loss to approximately $90 \%$ of pre-operative weight was observed. They then gradually became encephalopathic over a period of $48-72 \mathrm{hrs}$. When animals reached stage II - III encephalopathy, arginine infusions were carried out.

\section{Insulin and glucagon.}

After 1 week, basal insulin and -glucagon levels increased to approximately the same extent with a resulting normal insulin: glucagon molar ratio (figure 17). At 4 weeks, results were similar. Insulin and glucagon levels were increased to $200 \%$ of normal, but the ratio remained unchanged. When hepatic failure and encephalopathy supervened, basal glucagon levels showed a two- to tenfold increase as compared with pre-shunt values, but basal insulin levels tented to return to normal. Insulin: glucagon ratios thereby decreased to 0.9 as opposed to a normal ratio of approximately 3 (figure 17).

\section{Arginine infusion.}

After arginine infusion, insulin levels showed a sustained rise above basal levels pre-shunt and at 1 week post-shunt. After 4 weeks, however, or when the animals became encephalopathic, insulin levels dropped below basal levels after an initial rise in response to arginine infusion (figure 18). Basal plasma glucose levels were elevated at 1 and 4 weeks, and in encephalopathy above pre-shunt values (Table 7).

After infusion, glucose levels were lowered in encephalopathy, but hypoglycemic levels were never reached (Table 7).

Table 7:

Plasma glucose as measured in the basal state and following arginine infusion. *

\begin{tabular}{ccccc}
\hline \multicolumn{5}{c}{ Plasma glucose levels } \\
\hline \multicolumn{1}{c}{ Time } & Basal & $\begin{array}{c}\text { 1 week } \\
\text { post shunt }\end{array}$ & $\begin{array}{c}\text { 4 weeks } \\
\text { post shunt }\end{array}$ & $\begin{array}{l}\text { Encephalo- } \\
\text { pathy }\end{array}$ \\
\hline $\begin{array}{c}\text { Preinfusion } \\
\text { Postinfusion }\end{array}$ & $96.40 \pm 7.29$ & $104.0 \pm 7.19$ & $112.50 \pm 5.58$ & $105.40 \pm 15.7$ \\
2 min. & $107.25 \pm 5.89$ & $97.75 \pm 4.03$ & $107.25 \pm 9.83$ & $86.80 \pm 13.16$ \\
10 min. & $105.0 \pm 6.98$ & $101.50 \pm 5.12$ & $101.25 \pm 6.57$ & $85.0 \pm 10.16$ \\
30 min. & $106.75 \pm 3.12$ & $103.75 \pm 2.59$ & $108.5 \pm 10.43$ & $86.70 \pm 17.50$ \\
50 min. & $133.25 \pm 26.84$ & $94.75 \pm 2.81$ & $99.75 \pm 3.20$ & $83.4 \pm 7.17$ \\
\hline
\end{tabular}

*The samples were taken preinfusion and immediately following the cessation of infusion at $2,10,30$, and 50 min. following arginine infusion as described in the text. Note that no hypoglycemic levels are achieved. Results are given as mean \pm SEM for groups of five animals. 
Amino acid analysis.

Plasma amino acid analysis showed changes similar to those previously reported. A selection is graphically depicted in figure 4 . Notable increases were observed in plasma-tyrosine and phenylalanine which increased $300-$ $400 \%$. The branched-chain amino acids, leucine, isoleucine and valine were decreased slightly at 1 and 4 weeks, but returned to normal when the animal became encephalopathic (figure 4, table 4).

\subsection{Discussion}

A number of investigators have recently suggested that derangements in amino acid pattern may be causally related to hepatic encephalopathy, and that normalization of these amino acids either by infusion or dialysis techniques may result in awakening from hepatic coma $(28,34,36,37,46,53$,

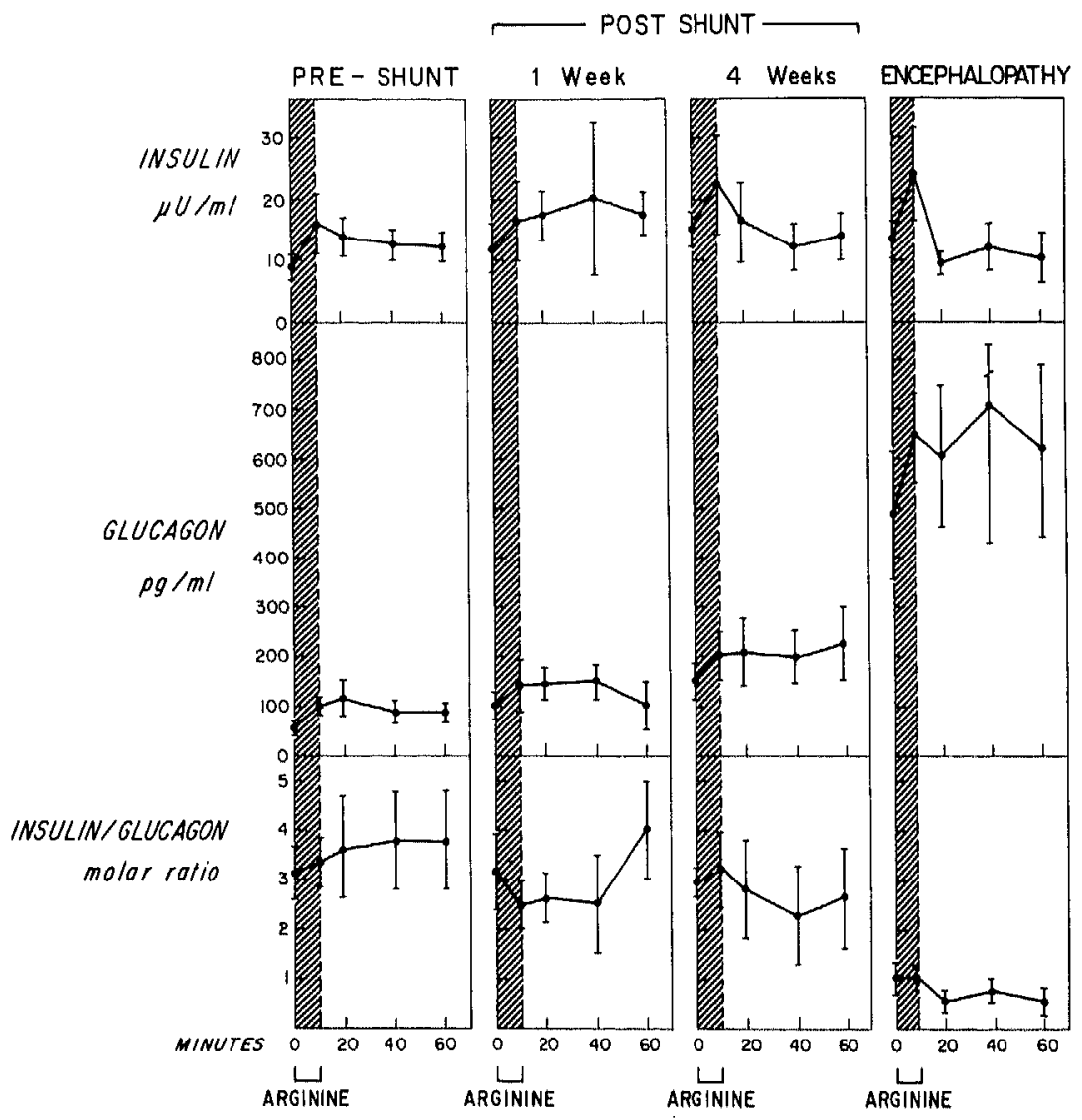

Figure 18: insulin, glucagon, and insulin: glucagon molar ratios in dogs following end-to-side porta-caval shunt: preshunt, at 1 and 4 weeks postshunt, and in encephalopathy. Arginine infusions were carried out over 10 minutes as described in the test. insulin, glucagon, and insulin : glucagon ratio are calculated for each point. The results are means \pm SEM for groups of flve animals. 
$74,84)$. Since some of the hormones, notably insulin and glucagon are intimately involved in the metabolism of these amino acids, investigation of their possible roles in hepatic encephalopathy is a natural extension of this work. Alterations in insulin (notably hyperinsulinemia) and a modest hyperglucagonemia have been related by some investigators (46) to shunting of portal blood around the liver. In these studies, we have attempted to define the respective roles of shunting of portal blood around the liver and the contribution of metabolic alterations brought on by deteriorating hepatic function to the hyperinsulinemia and hyperglucagonemia which accompany hepatic decompensation. These studies reveal that, although modest hyperinsulinemia and hyperglucagonemia are present from early on after shunt, the metabolic alterations which presumably accompany profound hepatic failure, result in a divergence in the behaviour of the plasma concentrations of these hormones. Whereas insulin remains only modestly elevated or even returns to normal pre-shunt levels, hyperglucagonemia increases $500 \%$ in animals with profound hepatic failure. Thus, it appears that extreme hyperglucagonemia coincides and therefore is probably caused by severe hepatic failure per se, and not by portal systemic shunting. Such a marked increase of a peptide hormone of gut origin may not be unique for glucagon as vasoactive intestinal peptide, a 28 amino acid peptide, and a candidate hormone in the gut also exhibits similar behaviour (85).

In a recent report, Ebeid et al (85) noted modest to insignificant increases in plasma vasointestinal peptide following porta-caval shunt in dog and man, whereas when hepatic failure supervened, marked increases in vasointestinal peptide occurred, thereby suggesting that this behaviour may be universal for members of the secretin family. The reason for this marked hyperglucagonemia is not clear. Plasma glucose levels were normal or even elevated at all times during hepatic encephalopathy, suggesting that lack of glucose does not seem to have occurred. A good correlation between catecholamines and glucagon levels has been demonstrated in burn-patients (78) suggesting that catecholamines may elicit glucagon secretion. Indirect evidence however exists that catecholamine levels are depressed in hepatic encephalopathy, in a manner similar to the changes observed in brains of rats in experimental hepatic encephalopathy (86).

Some authors have suggested that portal systemic shunting of pancreatic blood around the liver may diminish glucagon degradation (75). The five-fold increase of glucagon levels in hepatic encephalopathy however, cannot be explained on this basis, suggesting that a hypersecretion is occurring. In addition, glucagon is mainly degraded in the kidney and renal insufficiency did not occur in any of the dogs studied (chapter 2). Another possibility remains, that glucagon is released by accumulation of amino acids, as many amino acids have been shown (68) to stimulate the $\alpha$ cell secretion of glucagon and hepatic insufficiency is associated with increases in concentrations of most plasma amino acids and other small nitrogen containing molecules like $\mathrm{NH}_{3}$ and Mercaptans. Values reported in table 4 and figure 4 do not show spectacular rises, but when glutamine and $\mathrm{NH}_{3}$ are taken into account, very significant increases in small nitrogen containing molecules are observed. Apart from this phenomenon, recent data suggest 
that turn-over of at least the neutral amino acids is enhanced across the blood-brain barrier of rats in experimental hepatic encephalopathy. Thus, no easy explanation for extreme hyperglucagonemia in hepatic encephalopathy can be given, but it seems that hyperglucagonemia is most pronounced when liver function deteriorates and correlates with hyperaminoacidemia. Plasma insulin levels increase after porta-caval shunt, but normalize or decrease to below-normal levels in hepatic encephalopathy. This shows that hyperinsulinemia itself, cannot play a role in the pathogenesis of hepatic encephalopathy, as has been claimed by some authors (76).

In hepatic encephalopathy, experimental dogs are very catabolic as expressed in rapid weight losses and nitrogen losses. Therefore, hyperglucagonemia in hepatic encephalopathy is not surprising as all catabolic states $(77,78,89)$ are characterized by high glucagon levels and by lysis of body cell mass, flooding the circulation with protein breakdown products. These may stimulate glucagon secretion. Glucagon's major target organ is the liver, and glucagon induces enzyme systems in the liver, which enhance breakdown of amino acids, glutamine and alanine quantitatively being the most important. Thus, in this extrapolative view, hyperglucagonism is an obligatory sequel of the hypernitrogenous state, elicited by a failing liver and serving the purpose to stimulate that liver to relieve this hypernitrogenous state. The genesis of hyperinsulinism is even more speculative.

Hyperglucagonism itself may cause hyperinsulinism. In addition, increased glucose production and turn-over which has been demonstrated in septic states, but which we did not examine in hepatic encephalopathy, may cause hyperinsulinism. When liver function deteriorates even further, glucose production may diminish, causing insulin levels to decrease. Possible roles of insulin and glucagon are discussed more extensively in chapter 7.

\subsection{Summary}

Hyperinsulinemia and hyperglucagonemia have been recently proposed as being involved in the alterations in plasma amino acids in hepatic failure. In order to determine whether shunting of portal blood itself or decreases in hepatic function were more influential in these hormonal changes, end-toside porta-caval shunts were carried out and serial plasma insulin, glucagon, glucose and amino acid profiles were determined as the animals matured after shunt developing hepatic failure.

Arginine infusions were carried out as well in serial fashion.

1. A modest hyperinsulinemia was observed after porta-caval shunt. Insulin levels tended to normalize however in hepatic encephalopathy.

2. A modest hyperglucagonemia developed after porta-caval shunt. Hyperglucagonemia became marked in association with hepatic encephalopathy, and coincided with a high catabolic rate.

3. Hyperaminoacidemia was most pronounced during hepatic encephalopathy and a possible relationship with hyperglucagonemia and the catabolic state is discussed.

4. An inverse relationship between plasma branched-chain amino acid levels and insulin levels was noted and a possible relationship is discussed. 


\title{
Chapter 4
}

\author{
Relief of hepatic encephalopathy with specific amino acid-glucose \\ mixtures in man.
}

\subsection{Introduction}

The provision of adequate nutrition in patients with cirrhosis and hepatitis has been limited by protein intolerance manifested as hepatic encephalopathy, although adequate amounts of calories may be supplied intravenously or orally as carbohydrates.

As an extension of the study described in chapter 2 , a pilot study was done in man suffering from hepatic encephalopathy and employing the same specific amino acid solution, used in the dog study (table 1). When dogs with end-toside porta-caval shunts develop encephalopathy, the plasma amino acid pattern is similar to that seen in man with hepatic encephalopathy $(34,36$, $37,53,73,74$ ).

In this study, we tested the possibility, inferred from the dog study that a specific amino acid-glucose mixture (Hepatic Failure Solution) might improve hepatic encephalopathy or at least enable us to feed patients adequate amounts of nitrogen without aggravating hepatic encephalopathy.

\subsection{Materials and methods}

Eleven patients admitted to the Massachusetts General Hospital and manifesting hepatic encephalopathy at some time during their hospitalcourse are the subjects of this report (table 8 ). All required parenteral nutrition at some time during their hospitalcourse and were intolerant of available standard solutions. Criteria for inclusion, in addition to the requirement for parenteral nutrition, were the presence of hepatic encephalopathy and any three of the following four:

1. serum bilirubin in excess of $2.5 \mathrm{mg}$ per $100 \mathrm{ml}$;

2. serum glutamic oxaloacetic acid (SGOT) greater than $80 \mathrm{U}$ per ml (normal range: $10-40 \mathrm{U} / \mathrm{ml}$ );

3. prothrombin time greater than 2.5 seconds prolonged over control; 4. serum albumin less than $3.0 \mathrm{mg}$ per $100 \mathrm{ml}$ (prior to supplementation). Almost all patients fulfilled all four criteria. There were seven men and four women (table 8 ). Their age ranged between 34 and 74 years of age, with a mean age of 59.8. Patients were divided into two groups based on aetiology. Group 1 consisted of eight patients with chronic liver disease and cirrhosis with superimposed acute insults, i.e. gastro-intestinal bleeding and/or alcoholic hepatitis. Group 2 consisted of three patients with acute fulminant hepatitis and with no previous history of liver disease. The fulminant hepatitis was of type $B$ viral aetiology, confirmed by radioimmunoassay in all three patients. Prior to, and during infusional therapy, the following studies were undertaken: plasma amino acids, serum octopamine, blood ammonia, "liver chemistries", electrolytes, blood urea nitrogen, creatinine, prothrom- 
bin-time, and partial thromboplastin time. Electro-encephalograms were obtained as well. Chemistries were repeated every other day. Patients were evaluated daily neurologically as well as with Reitan trail tests when physically and neurologically able to do so. The encephalopathic grade was assessed according to the classification of Adams and Foley:

Grade I:

Fluctuant mild confusion, with euphoria and/or depression, slowed speech, disorder of sleeprythm.

Grade II:

(impending coma). Accentuation of grade I with drowsiness, inappropriate behaviour, and inability to maintain sphincter control.

Grade III:

(stupor). Sleeps most of the time but arousable; marked confusion is present with lack of knowledge of surroundings.

Grade IV:

(coma). Physical responses to painful stimuli may or may not be present. Blood octopamine was determined by the method of Molinoff and Axelrod (25). Infusional therapy was carried out with a 23 percent hypertonic dextrose infusion containing $40 \mathrm{~g}$ of synthetic amino acids of known composition (Hepatic Failure Solution; F080) (table 1), containing extra branched-chain amino acids compared to commercial synthetic amino acid mixtures and less phenylalanine, methionine, tryptophan and glycine.

Patients with liver disease requiring parenteral nutrition were started on low

Table 8:

Patient profiles

\begin{tabular}{lll}
\hline Patient & Age Sex & Diagnosis \\
\hline
\end{tabular}

Group I:

M.S. $\quad 66 \quad M \quad$ Laennec's cirrhosis; bleeding varices

G.H. $\quad 72 \quad F \quad$ Laennec's cirrhosis; bleeding varices

J.H. $\quad 60 \quad F \quad$ Laennec's cirrhosis; gastritis; alcoholic

R.C. $\quad 34 \quad M \quad \begin{aligned} & \text { hepatitis. } \\ & \text { Laennec's cirrhosis; alcoholic hepatitis }\end{aligned}$

H.D. $\quad 62 \quad M \quad$ Postnecrotic cirrhosis

R.W. $\quad 43 \quad M \quad$ Laennec's cirrhosis: bleeding varices

M.F. $\quad 74 \quad M \quad$ Postnecrotic cirrhosis

J.S. $\quad 64 \quad \mathrm{M} \quad$ Chronic active hepatitis.

Group II:

M.K. $\quad 47 \quad$ F $\quad$ Acute viral hepatitis - Type B

F.W. $\quad 48 \quad M \quad$ Acute viral hepatitis - Type B

M.S. $\quad 68 \quad F \quad$ Acute viral hepatitis-Type B 
doses of a commercial solution of ordinary composition (table 1) (Freamine II) at an initial dose of approximately $40 \mathrm{~g}$ of amino acids per 24 hours. If encephalopathy manifested itself, the commercial solution was discontinued and the Hepatic Failure Solution (F080) was begun. In patients, who already manifested grades II and III encephalopathy, infusional therapy was started with Hepatic Failure Solution (F080). Infusions of Hepatic Failure Solution (F080) were begun at a rate of 0.5 to $0.8 \mathrm{~g}$ of amino acid per kilogram per 24 hours. Dosage was increased by 0.125 to $0.250 \mathrm{~g}$ of amino acids per kilogram per 24 hours at 24 to 48 hours intervals, provided that 1) the patients' neurological condition did not deteriorate, or if it did, that no obvious cause was apparent, i.e., gastro-intestinal bleeding, hypokalemia, sepsis, etc. and that 2) significant increases in blood urea nitrogen did not occur. Total dosage of amino acids did not exceed $2.25 \mathrm{~g}$ of amino acids $/ \mathrm{kg} / 24 \mathrm{hrs}$ in any patient. Other treatments for hepatic insufficiency were continued when appropriate.

\subsection{Results}

In analyzing the results, the patients seemed to segregate into two groups based on aetiology, group 1, chronic liver disease, and group 2, acute hepatitis. Results will be discussed as such.

\section{Liver chemistries}

Group 1:

Mean bilirubin prior to the start of therapy was $12.05 \pm 4.22 \mathrm{mg}$ per $100 \mathrm{ml}$. SGOT levels were $78.75 \pm 20 \mathrm{U}$ per $\mathrm{l}$.

Alkaline phosphatase was elevated variably. Following infusion therapy, there was no statistically significant change in either bilirubin or SGOT.

Group 2:

Mean bilirubin and SGOT levels prior to infusion were considerably higher in this group. Mean serum bilirubin was $31.67 \pm 9.5 \mathrm{mg}$ per $1000 \mathrm{ml}$ and SGOT was $688 \pm 407.8 \mathrm{U}$ per $\mathrm{ml}$. No correlation was demonstrated between enzyme levels and infusional therapy.

\section{Albumin}

Albumin levels were below $3 \mathrm{mg}$ per $1 \mathrm{ml}$ in all patients at the time therapy was initiated. In most patients requiring parenteral nutrition, no significant rise was seen in the serum albumin over the period of parenteral nutrition as albumin infusions were used in both groups of patients.

\section{Prothrombin time}

Prothrombin time ranged between 2 and 4 seconds, elevated, in group 1 patients and greater than 5 seconds, elevated, in all the patients in group 2 , despite vitamin $\mathrm{K}$ administration. There were no statistically significant changes in prothrombin time with infusion therapy.

\section{Serum ammonia}

Group 1.

Mean blood ammonia prior to infusion therapy was $214.29 \pm 5.71 \mu \mathrm{g}$ per 
$100 \mathrm{ml}$. An inverse, statistically significant correlation was demonstrated between ammonia levels and dosage of F080 in terms of grams of amino acids per 24 hours (figure 19).

Serum ammonia concentrations also were noted to correlate well with episodes of infection and sepsis.

Group 2.

Mean plasma ammonia before infusional therapy was $175 \pm 25 \mu \mathrm{g}$ per $100 \mathrm{ml}$. No correlation was seen between ammonia levels and the dosage of Hepatic Failure Solution (F080) infused (figure 19).

\section{Blood octopamine}

Group 1.

Mean pretreatment octopamine concentrations were elevated, $7.5 \pm 2.9 \mathrm{ng}$ per $\mathrm{ml}$, normal being less than one $\mathrm{ng}$ per $\mathrm{ml}$ in this laboratory. A significant correlation was demonstrated between octopamine levels and Hepatic Failure Solution (F080) dosage (figure 20), as well as between blood octopamine levels and encephalopathic scores.

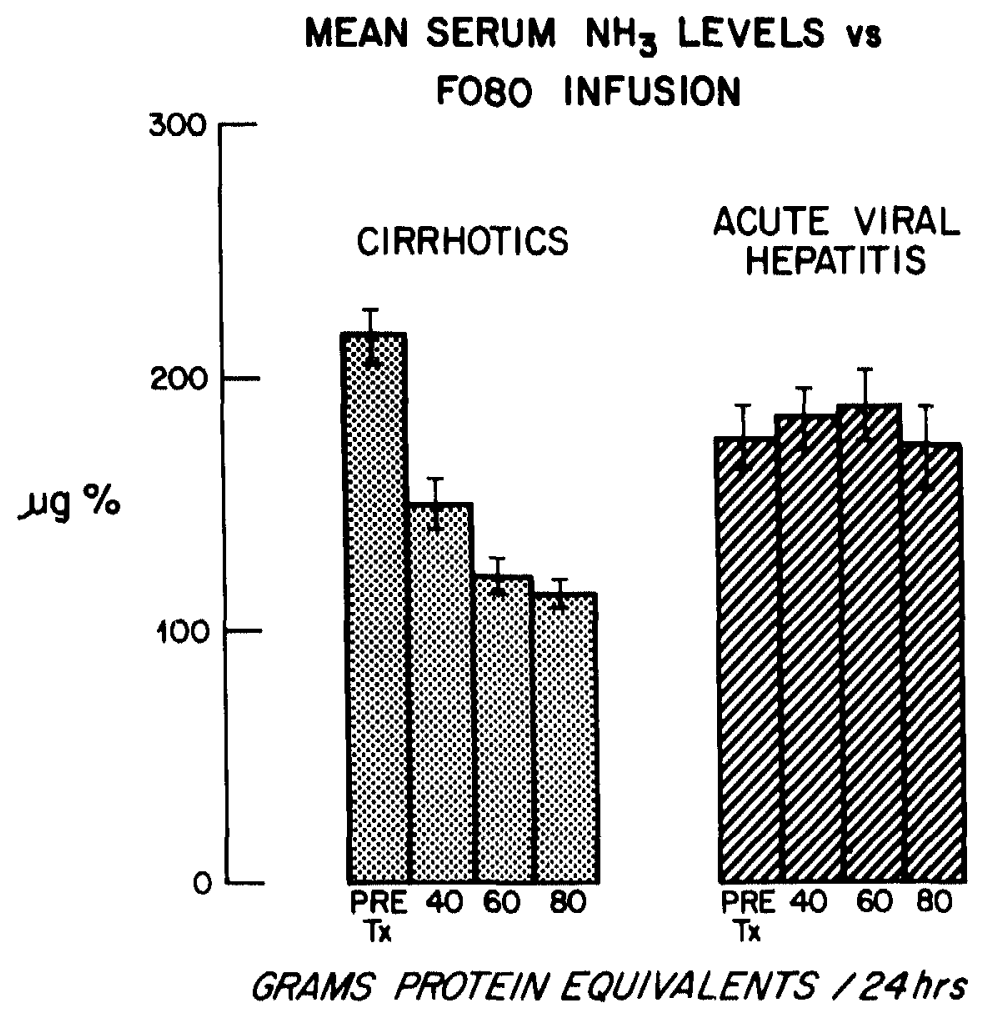

Figure 19: Mean serum ammonia levels vs F080 infusions are given in two groups. Note the rapid fall in blood ammonia in group 1 , with the cirrhotic patients returning to near normal at an infusion of $80 \mathrm{~g}$ of amino acids per 24 hours. There is no correlation seen in the acute viral hepatitis group. 
Group 2.

Only one patient in group 2 had serial octopamine determinations carried out. Pretreatment level was $2.5 \mathrm{ng}$ per $\mathrm{ml}$, which is elevated and consistent with grade ll encephalopathy present. No correlation was found between infusional therapy and plasma levels in this patient, as plasma octopamine remained at approximately $3 \mathrm{ng}$ per $\mathrm{ml}$.

Electroencephalograms.

Electroencephalograms were taken in seven of the eight patients prior to therapy in group 1 and in two of the three patients in group 2. Electroencephalograms were abnormal in all patients, showing diffuse slowing with theta frequency predominating as well as triphasic waves. In general, initial improvement was seen 24 hours following the initiation of F080 therapy. In those patients in whom complete neurological clearing occurred, electroencephalograms were normal within 48 to 72 hours after the beginning of F080 therapy (figure 21).

\section{MEAN PLASMA OCTOPAMINE LEVELS vS FO8O INFUSION IN CIRRHOTICS}

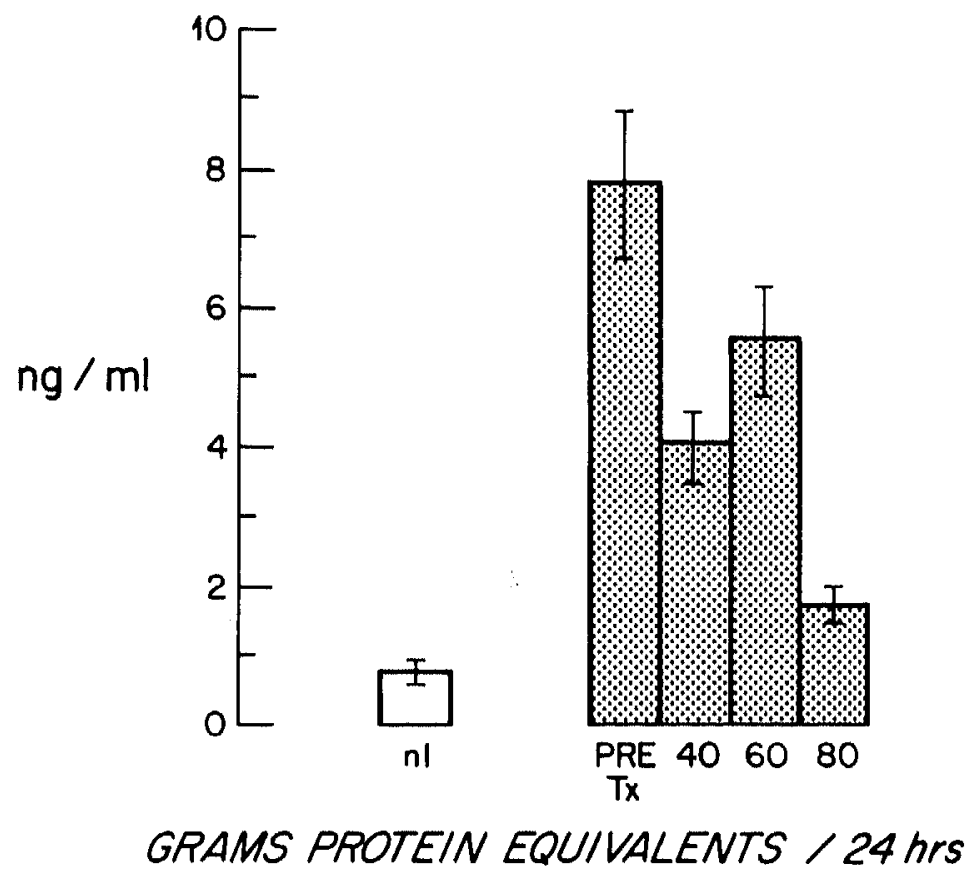

Figure 20: Mean plasma octopamine levels vs F080 infusion in cirrhotic patients, plasma octopamine was elevated before treatment and returned to near normal at $80 \mathrm{~g}$ of amino acids per 24 hours. Sufficient numbers of samples were not available in group 2 to make a significant correlation. 

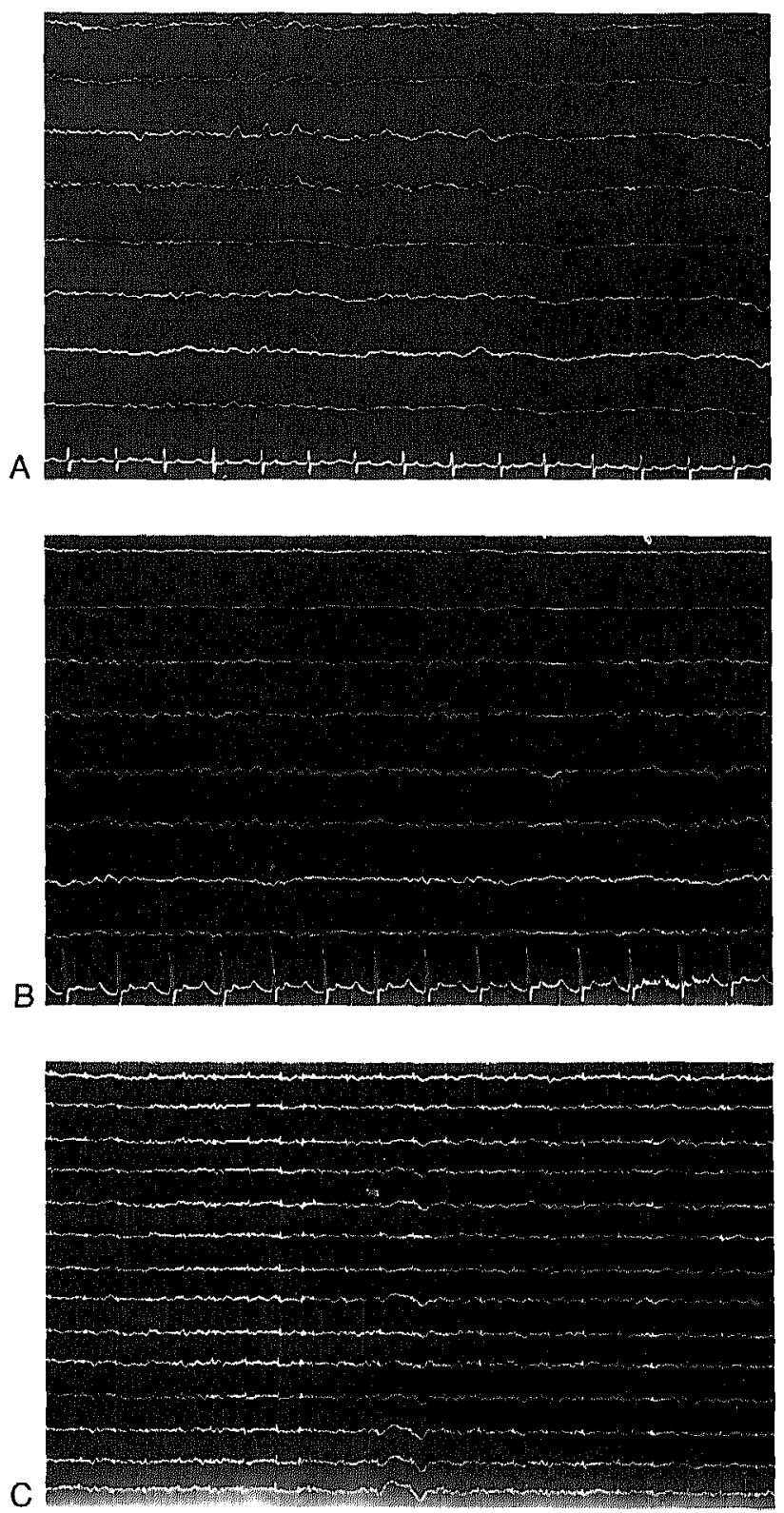

Figure 21: A sample of electroencephalogram of a patient.

Group 1: A. Diffuse slowing and triphasic waves pretreatment. B. A much more rapid rhythm, although some slowing is still seen in this portion of the tracing 24 hours after the onset of therapy; and C. A near-normal tracing 48 hours after therapy has begun. 
Mean encephalopathic scores.

Encephalopathic scores were determined on the basis of neurological examination and, in those patients who were capable of performing a Reitan trail test, at the time achieved.

\section{Group 1.}

Mean encephalopathic score immediately prior to F080 infusion was 3.38 \pm 0.26 . All patients in this group showed considerable neurological improvement during infusional therapy. Improvement was seen within the first 24 hours and appeared to be dose related (figure 22). The greatest improvement was seen in the dosage range of 60 to $80 \mathrm{~g}$ of amino acids per 24 hours or 1 to $1.25 \mathrm{~g}$ of amino acids per kilogram per 24 hours. Larger doses of amino acids were given in some patients with continued improvement, although the numbers of patients were small.

\section{Group 2.}

Mean encephalopathic grade immediately prior to infusion was $3.0 \pm 0.3$. Although all three patients initially showed neurological improvement, only one patient, the ultimate survivor, showed a significant decrease in

\section{MEAN ENCEPHALOPATHIC SCORES VS FO8O INFUSION}

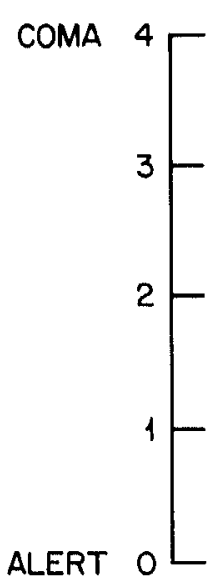

\section{CIRRHOTICS}

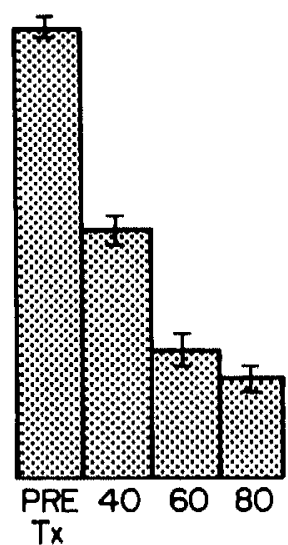

ACUTE VIRAL HEPATITIS

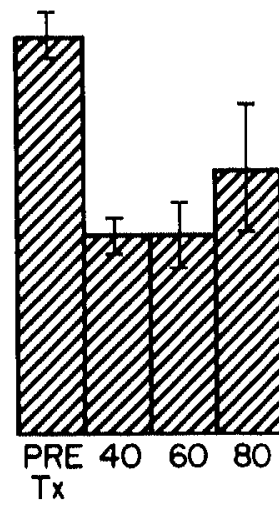

TX

Flgure 22: Mean encephalopathic scores vs F080 infusion in the two groups. Note that in the patients with cirrhosis there is a rapid return toward near normal as the rate of $80 \mathrm{~g}$ of amino acids per 24 hours is achieved. In the patients with acute viral hepatitis, only one patient improved and the other two rapidly became uremic. 
encephalopathic score which was sustained. Taking the small number of three patients as a group, there was no correlation between dosage of F080 and improvement. The reasons for this will be discussed.

\section{Survival}

\section{Group 1.}

Four of the eight patients died. One patient died in hepatic encephalopathy with hepatorenal syndrome following an ascitic leak, secondary to laparotomy carried out at another institution prior to transfer. Two patients ultimately died from gram-negative sepsis, unrelated to parenteral nutrition catheters, after they apparently had recovered from their initial episode of hepatic encephalopathy with infusional therapy. A fourth death occurred secondary to massive gastro-intestinal bleeding from gastritis and hepatic encephalpathy. The other four patients survived. One died 2 months later at home of unrelenting alcoholic hepatitis.

\section{Group 2}

Two of the three patients died, both with hepatic encephalopathy and sepsis. In both of these patients, death shortly followed the onset of peritoneal dialysis, with massive fluid shifts leading to uncontrollable hypotension. The other patient survived and is well at present.

\section{Plasma amino acid patterns.}

Amino acid patterns differed markedly between the two groups. In group 1, the amino acid pattern was identical to those reported previously from this laboratory and other laboratories. In group 2, a markedly different amino acid pattern was seen, something which previous investigators have not to our knowledge, commented on in man. Because of these marked differences, they will be described separately (figure 23).

\section{Group 1.}

The plasma amino acid pattern in the eight patients with chronic liver disease showed increased phenylalanine and tyrosine, elevated to approximately 215 to 300 percent: phenylalanine, $22.13 \pm 2.01 \mu \mathrm{g}$ per $\mathrm{ml}$, tyrosine, $27.13 \pm 4.55$ $\mu \mathrm{g}$ per ml. Pretreatment levels of tryptophan were $12.69 \pm 2.25 \mu \mathrm{g} / \mathrm{ml}$, an insignificant elevation (figure 7). The level of total tryptophan is not reflected in the brain or central spinal fluid tryptophan in most patients because of other factors, including the ratio of free to total tryptophan, the other neutral amino acids as well as levels of albumin, etc.. Central spinal fluid tryptophan was not determined in these patients, but in other patients with encephalopathy, central spinal fluid tryptophan was markedly elevated. In previous studies in dogs, cisternal tryptophan was markedly elevated, despite only a modest increase in plasma total tryptophan.

Methionine levels were elevated; branched-chain amino acids - leucine, isoleucine, valine - were depressed, $6.77 \pm 0.8,2.0 \pm 0.7$, and $13.8 \pm 2.2 \mu \mathrm{g}$ per $\mathrm{ml}$, respectively. Threonine was decreased as well, $7.5 \pm 2.4 \mu \mathrm{g} / \mathrm{ml}$. Other amino acids elevated were aspartate, glutamate, and, to a lesser extent, ornithine. The other amino acids were generally within normal range (figure 

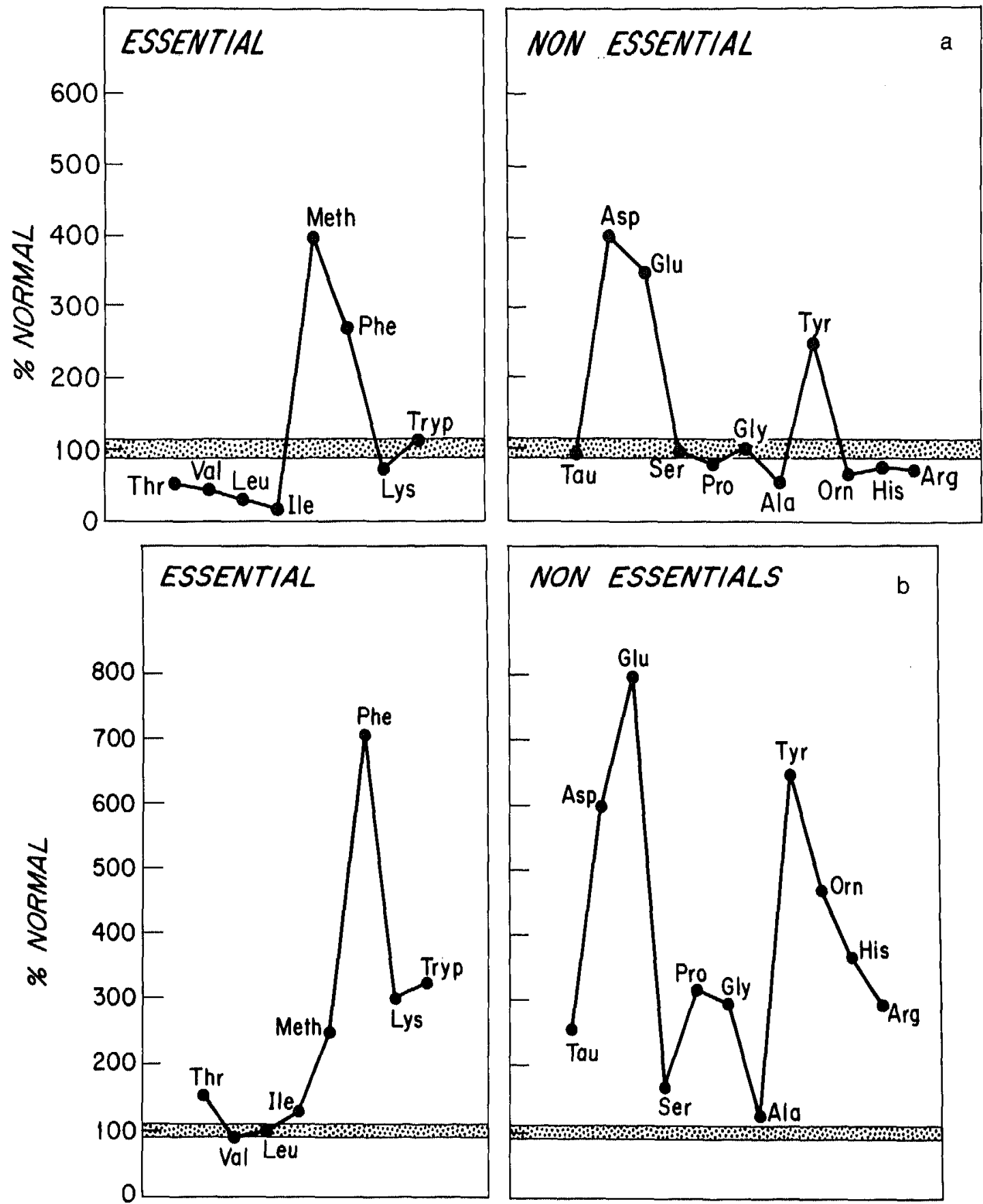

Figure 23: Amino acid patterns in group 1 (a), patients with cirrhosis, and group 2 (b), patients with viral hepatitis. The patterns are somewhat different. The patients with cirrhosis show increased phenylalanine and tyrosine, aspartate and glutamate, as well as methionine, whereas threonine and the branched-chain amino acids are decreased. In the patients with viral hepatitis all amino acids, with the exception of the branchedchain amino acids, are elevated. 
23). In several patients on whom serial blood samples were being drawn, episodes thought to precipitate hepatic encephalopathy, such as diuresis, sepsis, etc.. occurred intercurrently. Changes in plasma amino acid patterns occurred, apparently provoked by the episode. Schenker (90) has suggested "increased cerebral sensitivity" as explaining that a variety of seemingly unrelated stimuli may precipitate hepatic encephalopathy. These include sepsis, diuresis, and catecholamine discharge (in one patient a hypertensive crisis). In all patients in whom these episodes were observed, and whose encephalopathy worsened, alterations in plasma amino acid pattern occurred -including a sudden rise in plasma aromatic amino acids.

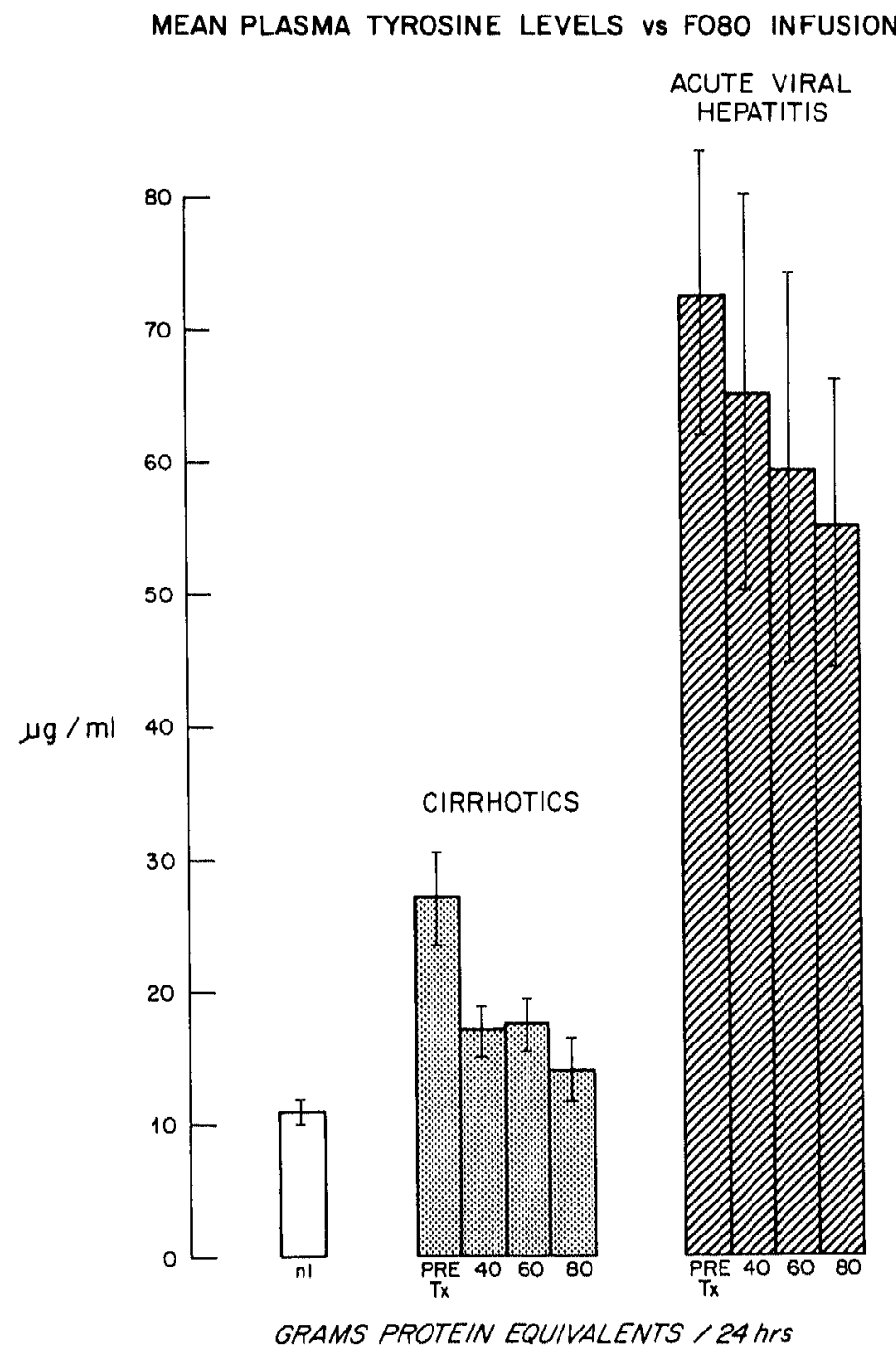

Figure 24 a: Response of plasma aromatic amino acid levels to F080 infusion in groups 1 and 2. a: mean plasma tyrosine levels vs F080 infusion. 


\section{Group 2.}

Patients with fulminant hepatitis.

A different amino acid pattern was seen in these patients. Extreme elevations in various amino acids were seen, of a different magnitude from those seen in patients with cirrhosis. Whereas phenylalanine was elevated to 30 or $40 \mu \mathrm{g}$ per $\mathrm{ml}$ in patients with chronic liver disease, in fulminant hepatitis plasma phenylalanine rose as high as $120 \mu \mathrm{g}$ per ml, with a mean of $60.83 \pm 19.91 \mu \mathrm{g}$ per $\mathrm{ml}$, tyrosine $72.51 \pm 34.1 \mu \mathrm{g}$ per $\mathrm{ml}$, and tryptophan $30.50 \pm 15.5 \mu \mathrm{g}$ per $\mathrm{ml}$ (figure $23 \mathrm{~b}$ ). Other amino acids were elevated, suggesting that there was wholesale release of amino acids from muscle or, most likely, liver.

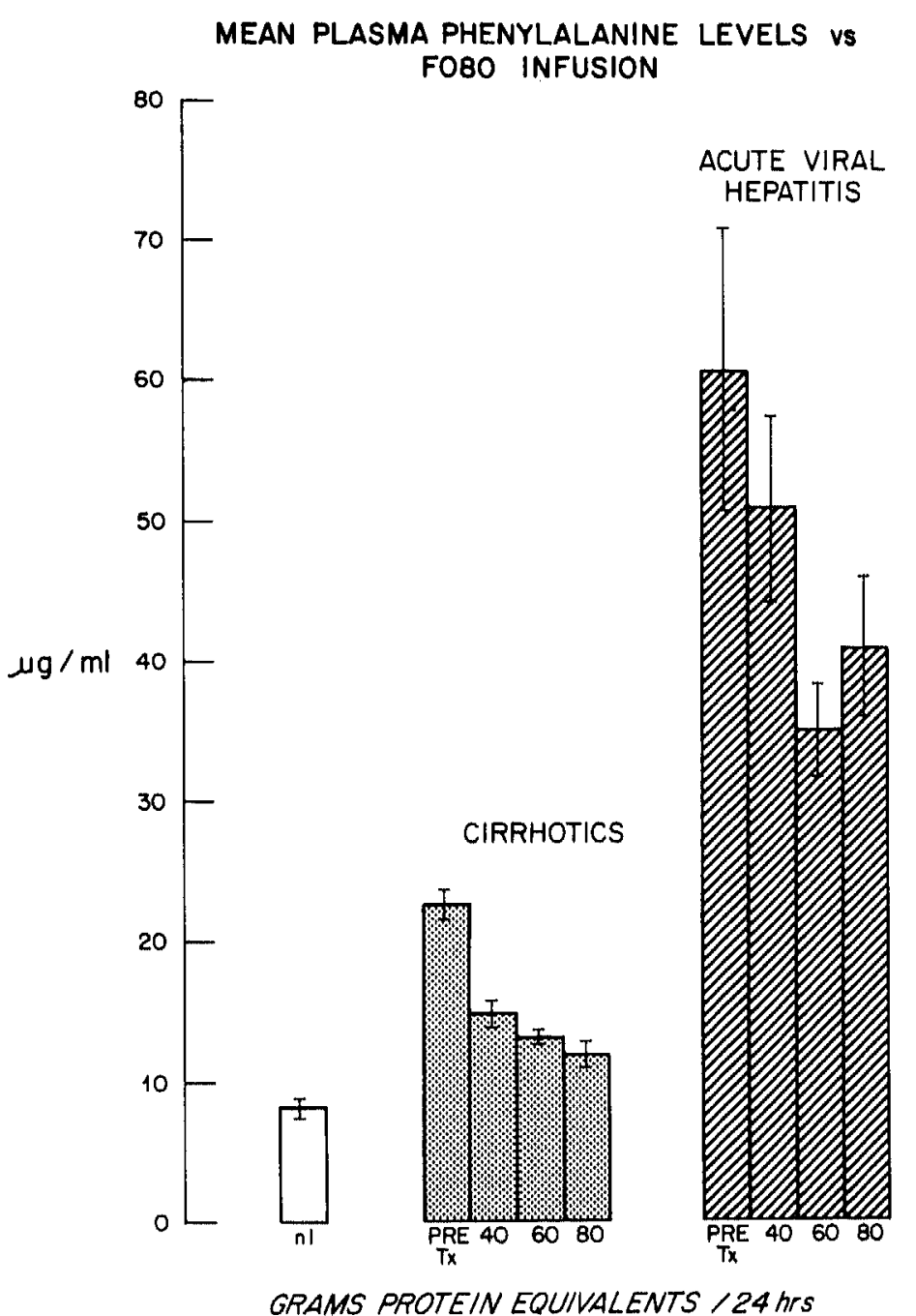

Figure 24 b: Response of plasma aromatic amino acld levels to F080 infusion in groups 1 and 2. b: mean plasma phenylalanine levels vs F080 infusion. 
The only amino acids not significantly elevated were the branched-chain amino acids, valine, leucine and isoleucine, which were normal: leucine, $16.67 \pm 7.86$; isoleucine, $13.67 \pm 7.06$; and valine, $25.33 \pm 57 \mu \mathrm{g} \mathrm{per} \mathrm{ml}$.

Results of infusional therapy.

Weight gain. Changes in the weight of these patients are difficult to interpret because of the attendent diuresis in many who had edema and ascites. Most patients lost weight with diuresis, partially diuretic-induced and partially the diuresis seen after the alleviation of starvation, a finding not unusual in patients being treated with parenteral nutrition after a period of relative starvation.

Nitrogen balance. Careful serial nitrogen balances were carried out on all of these patients. There was nitrogen retention in all patients, but only those patients in whom minimal rises in blood urea nitrogen occurred are

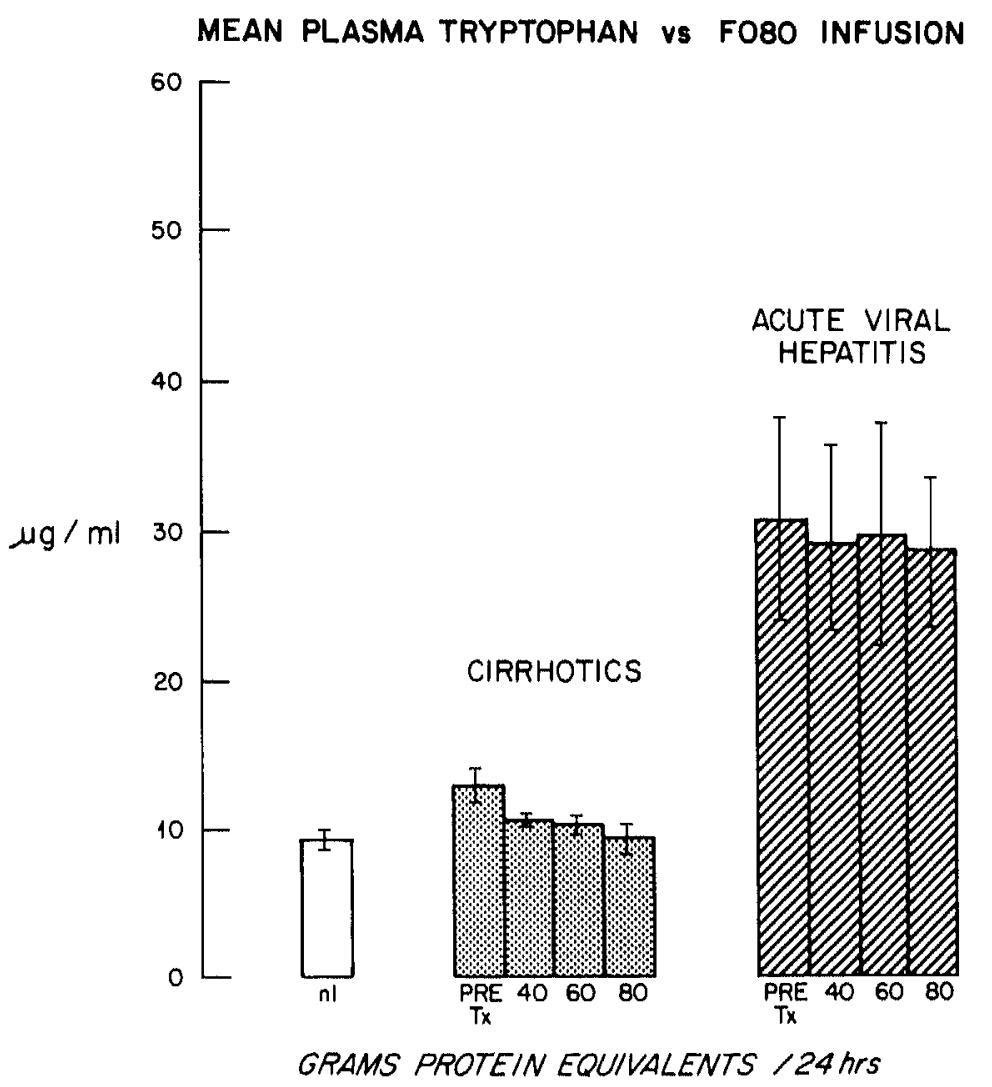

Figure $24 \mathrm{c}$ : Response of plesma aromatic amino acid levels to F080 infusion in groups 1 and 2. c: mean plasma tryptophan levels vs F080 infusion. Note that the initial levels are much higher in the patients with fulminant hepatitis. In group 1, phenylalanine and tyrosine return to near normal as does tryptophan with increased dosage. In group 2, there is a dose-response curve but it never achieves near-normal levels of the aromatic amino acids with the infusion rates used in the studies. 


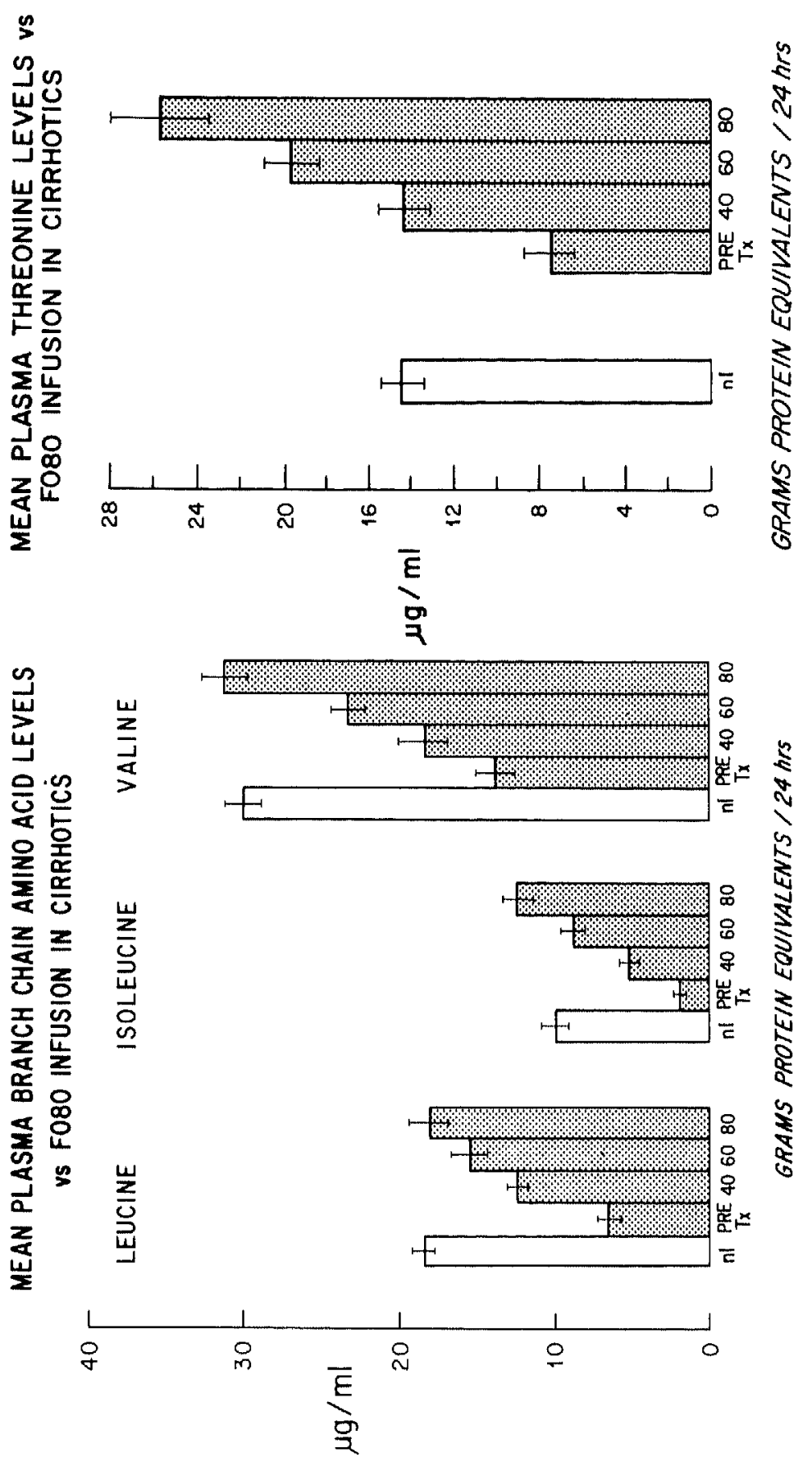

Figure 25: Response of the branched-chain amino aclds (left) and plasma threonine (right) levels to F080 infusion in cirrhotic patlents. Note that the decreased levels of plasma amino acids and threonine achieve normal levels in the case of the branched-chains with the infusion of $60 \mathrm{~g}$ of amino acids per 24 hours. With threonine, this appears to be achleved at a much slower rate of infusion, $40 \mathrm{~g}$ per 24 hours. 
considered valid. The mean nitrogen balance in five patients with chronic liver disease was $2.97 \pm 0.21 \mathrm{~g}$ of nitrogen per 24 hours, at an infusion rate of $80 \mathrm{~g}$ of amino acids per 24 hours. In one patient of group 2 with the least severe viral hepatitis in whom accurate nitrogen balances were possible, $3.5 \mathrm{~g}$ of nitrogen per 24 hours was retained at a steady state dose of $80 \mathrm{~g}$ of amino acids per 24 hours.

Response to amino acid infusion.

The clinical response to infusions of F080 as well as the plasma amino acid pattern was not the same in the two groups and therefore will be considered separately.

\section{Group 1.}

Amino acid pattern. A constant response pattern was seen, notably decreased aromatic amino acids, phenylalanine and tyrosine (figure $24, a, b$, c). The fall in methionine and trytophan was not considered significant.

Plasma branched-chain amino acids and threonine increased (figure 24). Infusions were begun at $40 \mathrm{cc}$ of solution per hour containing $40 \mathrm{~g}$ of amino acids per liter and $23 \%$ dextrose. Thus, in the first day most patients received

\section{MEAN PLASMA BRANCH CHAIN AMINO ACID LEVELS vs. F080 INFUSION IN ACUTE VIRAL HEPATITIS}
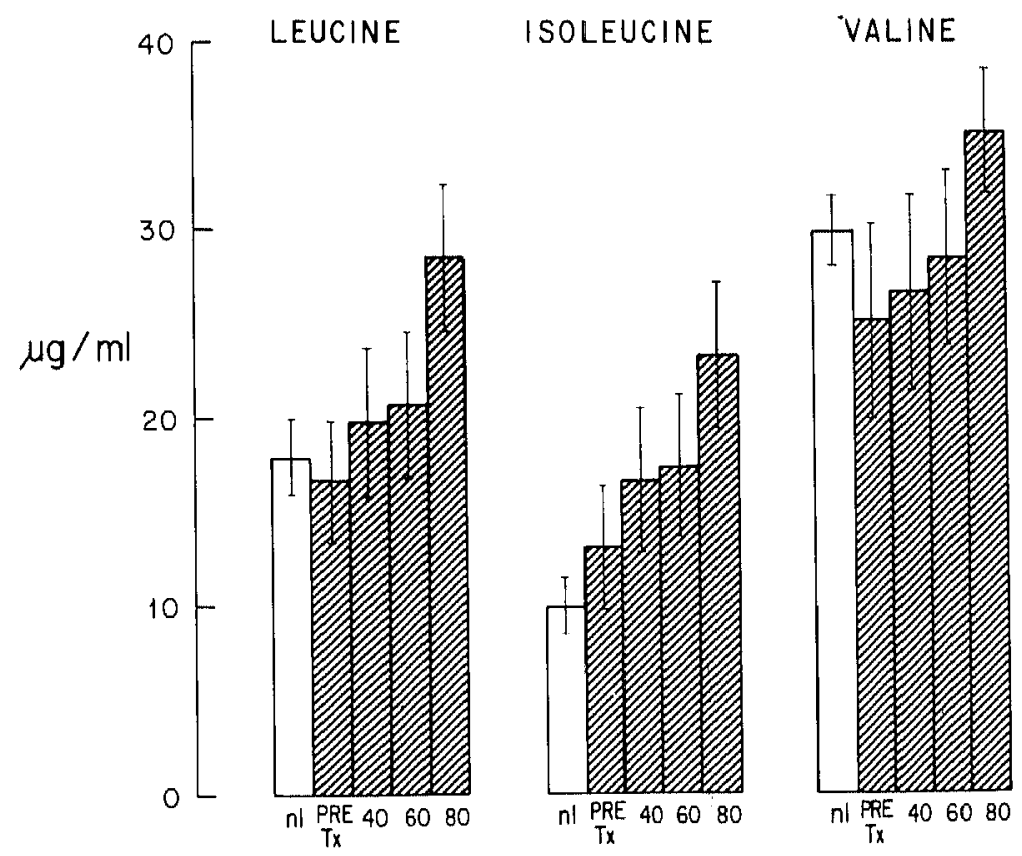

GRAMS PROTEIN EQUIVALENTS $/ 24 \mathrm{hrS}$

Figure 26: Mean plasma branched-chain amino acid levels of F080 infusions in acute viral hepatitis. In this group normal levels are achieved at lower levels of infusion since the levels were not decreased to begin with. group normal levels are achievedat lowor lovels or intusion sincothelevels wer not deceased to begln with. 
$40 \mathrm{~g}$ of amino acids and 1035 calories as glucose. This is equivalent in most patients to approximately $0.75 \mathrm{~g}$ of amino acid per kilogram per 24 hours. Dosage was increased at increments of 0.125 to $0.25 \mathrm{~g}$ of amino acid per 24 hours, depending on fluid tolerance, neurological state, etc.. Good correlation was seen between dosage of amino acids, the decrease in the aromatic amino acids, and the increase of the branched-chain amino acids yielding dose-response curves (figure 24 and 25). From the dose-response curve in this group of patients, it appears that an efficacious level of infusion at which the aromatics return to normal and the branched-chain amino acids return to approximately a normal level is equivalent to at least $80 \mathrm{~g}$ of amino acids per 24 hours. There was no correlation between dose and other amino acids in this group of patients.

Neurological status. The correlation of infusional rate with neurological state is, of course anecdotal, owing to the small number of patients, but it does seem that neurological improvement correlated with the alterations in plasma amino acid patterns. Consequently, although the increases in infusional rate were cautious in these patients, it would seem that, barring rises in blood urea nitrogen associated with renal functional impairment, a more rapid infusional rate with more rapid neurological improvement could be anticipated in the next group of patients. It does appear to be between 80 and $100 \mathrm{~g}$ of amino acids per 24 hours, although is some patients, the maximal effect in decreasing of plasma aromatic amino acids coincided with the maximal rate of infusion in these studies, $120 \mathrm{~g}$ of amino acids per 24 hours. Whether increasing rates of infusion beyond this would be benefical, is not clear.

\section{Group 2.}

Amino acid pattern. The extremely elevated levels of plasma amino acids in patients with fulminant hepatitis is due presumably to release of amino acids from damaged liver and muscle. Thus a dose-response curve obtained with the amount of infusion was unexpected, since such release was uncontrolled and due to dying hepatocytes. Surprisingly, dose-response curves were observed, although the slopes were considerably flatter than those seen in patients with cirrhosis (figure 24). Thus phenylalanine and tyrosine decreased in response to increased dosage of F080 and glucose. At no time did the plasma concentrations of these aromatic amino acids approach normal. Branched-chain amino acids increased as they did in the group 1 patients, but less rapidly (figure 26). The other amino acids remained elevated. We were limited in this group of patients by a rapid rise in blood urea nitrogen in one of the patients as well as the short duration of treatment in two. Both of these patients were seen rather late in their course, and although encephalopathy was grade III at the time they were seen, blood urea nitrogen was approximately 75 to $80 \mathrm{mg}$ per $100 \mathrm{ml}$ at the time the infusion was started. Thus the dose of amino acids had to remain low. Neurological status. As stated earlier, two patients died following institution of dialysis. Neurological state did not improve nor deteriorate. In the third patient, by far the least severe, encephalopathy improved within 24 hours and ultimately she survived. 


\section{Amino acid ratios}

It has been suggested previously that the ratio of the branched-chain amino acids : aromatic amino acids may determine in part the concentration of free amino acids within the brain (53). Thus in dog (53), man (53), and rat (47) the normal ratio between the molar concentrations of the branched-chain amino acids and phenylalanine, and tyrosine is approximately three. In man and dog in hepatic encephalopathy, this ratio drops to one (53). In previous experiments with a similar solution in dogs with end-to-side porta-caval shunts, the ratio returns to three when the animals approach neurological normality.

Calculations of the ratios in the patients suggest that in group 1 the ratio approaches three when patients improve to grade 0 or grade 1 encephalopathy (figure 27). In group 2, the point at which the patients manifested encephalopathy (figure 27) occurred when the levels of the branched-chain amino acids, due to the excessive elevation in aromatic amino acids, reduced the ratio to approximately one. In only one patient, one who has survived, was the ratio corrected to anywhere near 3.0 ; in the others, the ratio stayed near one, and encephalopathy persisted (figure 27).

\subsection{Discussion}

The most important finding of this study is the demonstration that protein intolerance may be ameliorated and adequate nutrition achieved in patients with hepatic failure by varying the composition of the amino acids administered.

Although these reports are limited to patients who are acutely ill and who require infusional therapy, there are many patients with chronic hepatic encephalopathy whose protein intolerance is such that adequate nutrition cannot be achieved. Elemental diets with defined amino acid composition

MEAN MOLAR RATIOS OF $\frac{V A L+L E U+I L E}{\text { PHE }+ \text { TYR }}$ V FOBO INFUSION; VS ENCEPHALOPATHIC SCORE IN CIRRHOTICS

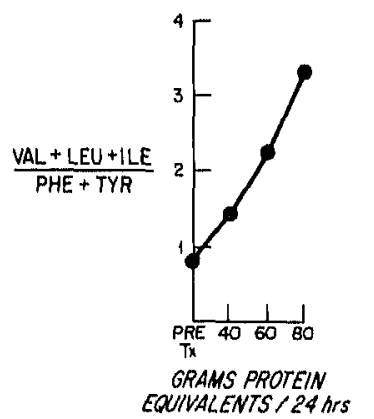

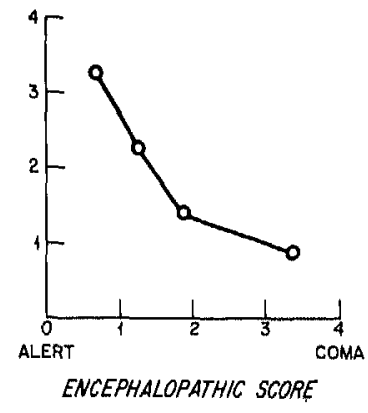

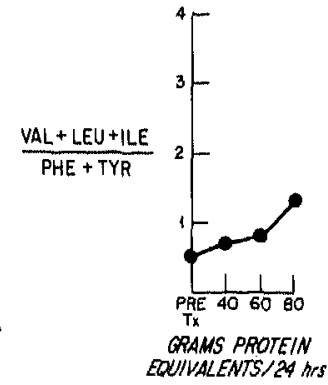

MEAN MOLAR RATIOS OF

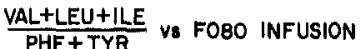
IN ACUTE VIRAL HEPATITIS

Figure 27: The mean molar ratios of the neutral amino acids as compared with infusion rates in patients with cirrhosis and in patients with viral hepatitis. Note that whereas in patients in cirrhosis the molar ratio returns to near normal at $80 \mathrm{~g}$ of protein per 24 hours, it does not in the group with hepatitis, owing to the very high levels of the aromatics. An excellent correlation appears to result when the molar ratios are compared with a level of hepatic coma in patients in the first group. 
may make adequate nutrition available to such patients. In this report, it not only appears that adequate amounts of amino acids can be fed, but also that at least in a small anecdotal group of patients with cirrhosis and chronic hepatic insufficiency hepatic encephalopathy is cleared and no toxicity is apparent. Coincident with this, is the finding that the pathologic amino acid pattern which was confirmed in this group of patients, was corrected (figures 24 and 25). We have not demonstrated directly that the deranged brain neurotransmitter pattern is related to hepatic encephalopathy. Even if this were demonstrated, we still have not shown that the correction of the plasma and presumably of the brain amino acid pattern leads to improvement in brain neurotransmitter profile.

A second important finding of this study is, that plasma amino acid patterns differ between patients with cirrhosis and chronic hepatic insufficiency and those with fulminant hepatitis. These differences are qualitative as well as quantitative. Whereas with alcoholic cirrhosis with hepatic encephalopathy, the aromatic amino acids, phenylalanine, tyrosine and methionine, are increased as are glutamate, aspartate and glycine, whereas the branchedchain amino acids are decreased, in fulminant hepatitis all amino acids are increased, but to a considerably greater extent than in cirrhosis (figure 23), with the exception of the branched-chain amino acids which are normal. This does not necessarily imply a different mechanism of encephalopathy, especially if the ratios between the two groups of neutral amino acids are more important than are their absolute amounts. The ratios between the aromatic amino acids and the branched-chain amino acids in fulminant hepatitis and encephalopathy are equally low as compared with patients with cirrhosis (figure 27).

A third important finding in this study is that those events which commonly precipitate hepatic encephalopathy, namely sepsis, diuretics-induced diuresis, catecholamine discharge, and non-specific stress (findings which have led Schenker and coworkers to enunciate the concept of "increased. cerebral sensitivity" (90)) resulted in the same plasma amino acid changes, namely increased aromatic amino acids and decreased plasma branchedchain amino acid levels. If the concept of ratios controlling the penetration of the toxic aromatic amino acids across the blood-brain barrier is correct, these plasma amino acid changes would lead to a derangement in brain concentrations of amino acids and thus in disturbances in concentrations of certain neurotransmitters.

The fourth finding is the dose-response curves (figures $19,22,24,25$ ) between infusion of a mixture calculated to normalize the plasma amino acids and the plasma amino acid concentrations. It is of interest that despite the fact that the solution contains some phenylalanine and tryptophan, these levels fall to their lowest point when the maximal rate of infusion was reached, i.e. $120 \mathrm{~g}$ per 24 hours. This suggests that either the release of these aromatic amino acids into the circulation was diminished, something which may be achieved by increasing protein sparing by $23 \%$ dextrose or/and that 
the aromatic amino acids were being utilized by incorporation into protein. This equally applies to plasma ammonia levels who paradoxically decrease further when more amino acids were infused. This same phenomenon was observed in the dog study (chapter 2). We will discuss this in more detail in chapter 7.

\subsection{Summary}

It has been suggested before that the plasma amino acid pattern known to be deranged in hepatic encephalopathy, may be related causally to hepatic encephalopathy. In order to test this hypothesis, $23 \%$ dextrose and a special amino acid solution whose components were calculated to normalize the plasma amino acid pattern were infused in 11 patients, 8 with alcoholic cirrhosis (group 1) and 3 with fulminant hepatitis (group 2) in amounts of up to $120 \mathrm{~g}$ of amino acids per 24 hours.

1. Plasma amino acids were abnormal but different in both groups. In group 1 (cirrhosis) changes in plasma amino acid pattern included elevated phenylalanine, tyrosine, glutamate, asparatate and methionine and decreased valine, leucine and isoleucine. In group 2, all amino acids were elevated, with the exception of the branched-chain amino acids which were normal.

2. Hepatic encephalopathy improved in all patients in group 1, and in one of three patients in group 2 following infusion. Consequently, it appears that adequate amounts of amino acids can be fed without deterioration of hepatic encephalopathy or even, at least in a small group of patients with alcoholic cirrhosis with improvement of neurological state.

3. Various events which commonly precipitate hepatic encephalopathy, namely sepsis, diuretics-induced diuresis, catecholamine discharge, etc. resulted in the same plasma amino acid changes, namely decreased plasma branched-chain amino acid concentrations and increased plasma aromatic amino acid concentrations.

4. Dose-response curves were observed: when more F080 was infused, lower concentrations of plasma aromatic amino acids and ammonia were observed, even though the solution contained some of these substances (phenylalanine and tryptophan). 


\title{
Chapter 5:
}

\author{
Influences of exogenous intake and nitrogen balance on plasma and brain \\ aromatic amino acid concentrations in rats with porta-caval shunts.
}

\subsection{Introduction}

In the previous chapters 2 and 4 , studies were carried out, the results of which suggest that normalization of plasma amino acid levels is of benefit in hepatic encephalopathy.

For obvious reasons, brain amino acid levels in these experiments were not available. Furthermore, the profound catabolic state encountered in starving dogs suffering from hepatic encephalopathy and the dose-response relationship between Hepatic Failure Solution (F080) infused and biochemical and clinical results obtained, led us to propose that achieving anabolism is beneficial in hepatic encephalopathy.

The following studies therefore were performed to determine if plasma concentrations of aromatic amino acids are reflected in brain aromatic amino acid levels and in brain octopamine levels and if plasma- and brain levels could be manipulated by infusing various amino acid formulations with hypertonic dextrose into rats following chronic porta-caval shunt. In the second part of these experiments, therefore an attempt was made to ascertain the influence of nitrogen balance by making groups of rats progressively more anabolic with increasing nitrogen intake.

\subsection{Materials and methods}

Influence of exogenous intake

Female Sprague Dawley rats weighing 200-250 g were divided in three groups of 20. Group 1 consisted of 10 rats that had undergone end-to-side porta-caval shunt (93) and 10 sham-operated rats. Following operation, the rats were allowed to feed freely in metabolic cages for a 4-wk period, after which blood was obtained by cardiac puncture and the rats were decapitated. Blood was centrifuged and rat brains were immediately harvested and frozen. Group 1 served as a control group for plasma and brain aromatic amino acid and octopamine levels in the freely feeding shunted and nonshunted rat. Group 2 consisted of 20 rats that had undergone sham operation. They were then allowed to feed freely for $3 \frac{1}{2}$ weeks, at which time internal jugular catheterization with 22-gauge medical grade silastic tubing was carried out. The animals were placed in metabolic cages, and intravenous nutrition was started. Water alone was provided ad libitum. Ten rats received Freamine II in $23 \%$ dextrose at a dose of $1 \mathrm{~g}$ amino acids $/ 100 \mathrm{~g}$ body weight $/ 24 \mathrm{hrs}$, while the remaining 10 rats received $F 080$ in isonitrogenous and isocaloric amounts (table 9). Rats were sacrificed 96 hours later and plasma and brains were harvested and frozen as described for group 1. Infusions were stopped $1 / 2 \mathrm{hr}$ prior to sacrifice. Group 2 served as another control group for plasma and brain aromatic amino acid and octopamine levels in nonshunted rats 
receiving either the commercial solution (Freamine II) or the Hepatic Failure Solution (F080).

Group 3 consisted of 20 rats that had undergone end-to-side porta-caval shunt, been allowed to freely feed for weeks, and then were hyperalimented (as in group 2) for a 96-hr period. Water alone was provided ad libitum. Ten rats received Freamine $\mathrm{II}$, and 10 rats received $\mathrm{F} 080$ at a dosage rate of 25 $\mathrm{cal} / 100 \mathrm{~g}$ body weight and $1 \mathrm{~g}$ amino acids $/ 100 \mathrm{~g}$ body weight $/ 24 \mathrm{hrs}$. After 96 hours, blood was obtained by cardiac puncture and brains were harvested following decapitation. Plasma and brains were immediately frozen.

Infusions were stopped $1 / 2 \mathrm{hr}$ prior to sacrifice.

All three groups had nitrogen balance studies done by the Kjeldahl method on the day before and the day of sacrifice.

Plasma phenylalanine and tyrosine levels were determined fluorometrically $(94,95)$. Tryptophan was determined fluorometrically by the method of Dencla and Dewey (55). Brain tyrosine and tryptophan were determined as above after homogenization and centrifugation. Brain octopamine was determined by the method of Molinoff and Axelrod (25) with minor modifications.

Table 9:

Composition of the synthetic amino acid solutions used in this experiment.

\begin{tabular}{lcc}
\hline & $\begin{array}{l}\text { F080* } \\
(\mathrm{g} / 1000 \mathrm{ml})\end{array}$ & $\begin{array}{l}\text { Freamine } \\
(\mathrm{g} / 1000 \mathrm{ml})\end{array}$ \\
\hline L-Isoleucine & 4.50 & 2.90 \\
L-Leucine & 5.50 & 4.25 \\
L-Valine & 4.20 & 2.80 \\
L-Lysine-HCl & 3.80 & 4.35 \\
L-Methionine & 0.50 & 2.25 \\
L-Phenylalanine & 0.50 & 2.30 \\
L-Threonine & 2.25 & 1.20 \\
L-Tryptophan & 0.38 & 0.65 \\
& & \\
Nonessential & & \\
L-Alanine & 3.75 & 3.00 \\
L-Arginine & 3.00 & 1.55 \\
L-Histidine & 1.20 & 1.20 \\
L-Proline & 4.00 & 4.75 \\
L-Serine & 2.50 & 2.50 \\
Glycine & 4.50 & 8.50 \\
L-Cysteine-HCl- $\mathrm{H}_{2} \mathrm{O}$ & 0.20 & 0.10 \\
& & \\
As given $(100 \mathrm{ml})$, with $230 \mathrm{~g}$ dextrose & & \\
Total nitrogen $(\mathrm{g})$ & 6.25 & 6.25 \\
Protein equivalent $(\mathrm{g})$ & 40 & 39 \\
\hline
\end{tabular}

"The F080 solution used is identical to that previously reported (56) and "normalizes" plasma amino acid concentrations in dogs and humans with chronic hepatic insufficiency. 
Effects of nitrogen balance on plasma and brain aromatic amino acids. Fifty 200-225 g female Sprague-Dawley rats underwent end-to-side portacaval anastomosis and were then allowed to feed freely for $31 / 2$ weeks. Rats were randomly divided into five groups of 10 . They then underwent open internal jugular venous catheterization with 22-gauge medical grade silicone tubing, and they were harnessed and placed in metabolic cages. Parenteral nutrition was begun for a $96-\mathrm{hr}$ period using F080. Water was allowed ad libitum. Urine was collected and nitrogen balance studies were determined by the Kjeldahl method. Dosage rates of amino acids $/ 100 \mathrm{~g}$ body weight $/ 24$ hrs were as follows : group $1,0 \mathrm{~g} ;$ group $2,0.25 \mathrm{~g}$; group $3,0.50 \mathrm{~g} ;$ group 4 , $0.75 \mathrm{~g}$; group $5,1.00 \mathrm{~g}$. All groups received isocaloric amounts of $23 \%$ dextrose at a dose of $25 \mathrm{cal} / 100 \mathrm{~g}$ body weight $/ 24 \mathrm{hrs}$.

On the fourth day rats were sacrificed and the plasma and brains were immediately harvested. Infusions were stopped $1 / 2 \mathrm{hr}$ prior to sacrifice. Plasma phenylalanine, tyrosine, and tryptophan and brain tyrosine, tryptophan, and octopamine were determined as described. Linear regression analysis and Student's $t$ test were used to demonstrate statistically significant correlations between nitrogen balance and amino acids.

\subsection{Results}

Influence of exogenous intake

Plasma aromatic amino acids and brain tyrosine, tryptophan, and octopamine in all three groups in the first series of experiments are shown in table 10. All values were significantly elevated in group 1 freely feeding portacaval shunted rats as compared to freely feeding sham-operated rats. No significant differences could be demonstrated between nonshunted group 2 rats, and group 1 nonshunted rats irrespective of the solution they received, either Freamine II or F080. Marked significant differences however, were observed in all parameters in both plasma and brain between group 3 shunted rats receiving the two different amino acid formulations. In addition, those shunted rats receiving the F080 formulation corrected all plasma and brain concentrations to normal, nonshunted, freely feeding concentrations except for plasma tyrosine, which was decreased, and plasma tryptophan, which remained slightly elevated. Plasma and brain concentrations of tryptophan correlated well, as did brain tyrosine and octopamine. These concentrations also varied directly with the amount of aromatic amino acids administered. Mean nitrogen balances done by the Kjeldahl technique were positive in all groups (table 11). In group 3 rats receiving F080 there seemed to be a trend toward an inverse relationship between degree of nitrogen balance positivity and plasma phenylalanine and tyrosine, and brain tyrosine and octopamine levels; as positive nitrogen balance increased, these parameters decreased. However, this correlation was not statistically significant, as nitrogen balances were all maintained in a relatively narrow range. Therefore, the second series of experiments was carried out. 
MEAN PLASMA PHENYLALANINE vs NITROGEN BALANCE

IN RATS

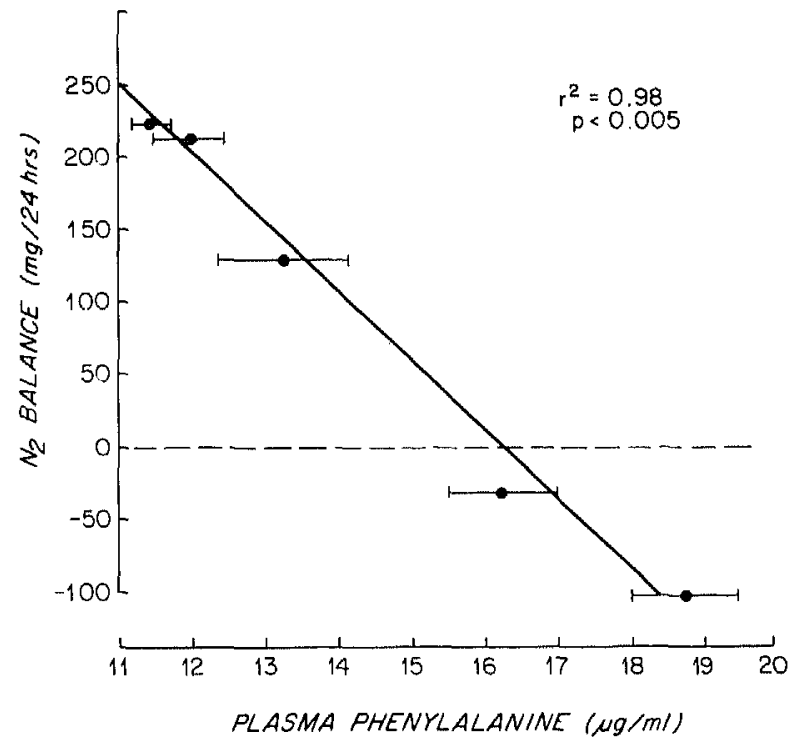

Figure 28: Mean plasma phenylatanine plotted against nitrogen balance for 5 groups of 10 rats each. Results are given as mean \pm SEM and are highly significant.

MEAN PLASMA TYROSINE VS NITROGEN BALANCE

IN RATS

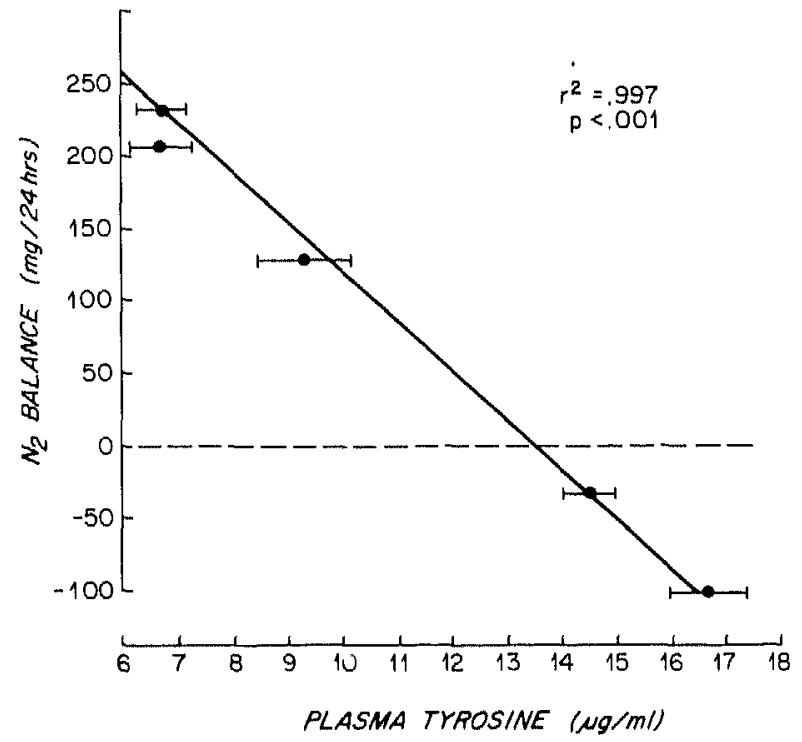

Figure 29: Mean plasma tyrosine plotted against nitrogen balance in 5 groups of 10 rats each. Results are given as mean \pm SEM and are highly significant. 


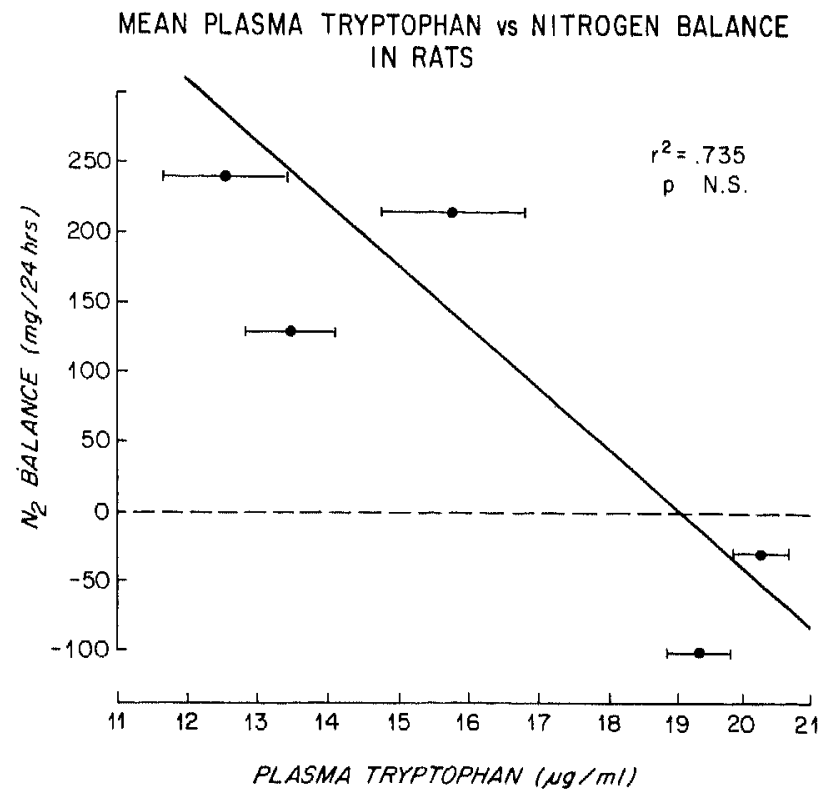

Figure 30: Mean plasma tryptophan plotted against nitrogen balance in 5 groups of 10 rats each receiving variable amounts of nitrogen plus hypertonic glucose as described in text. Although a rough correlation is seen, results are not statistically significant for reasons discussed in text.

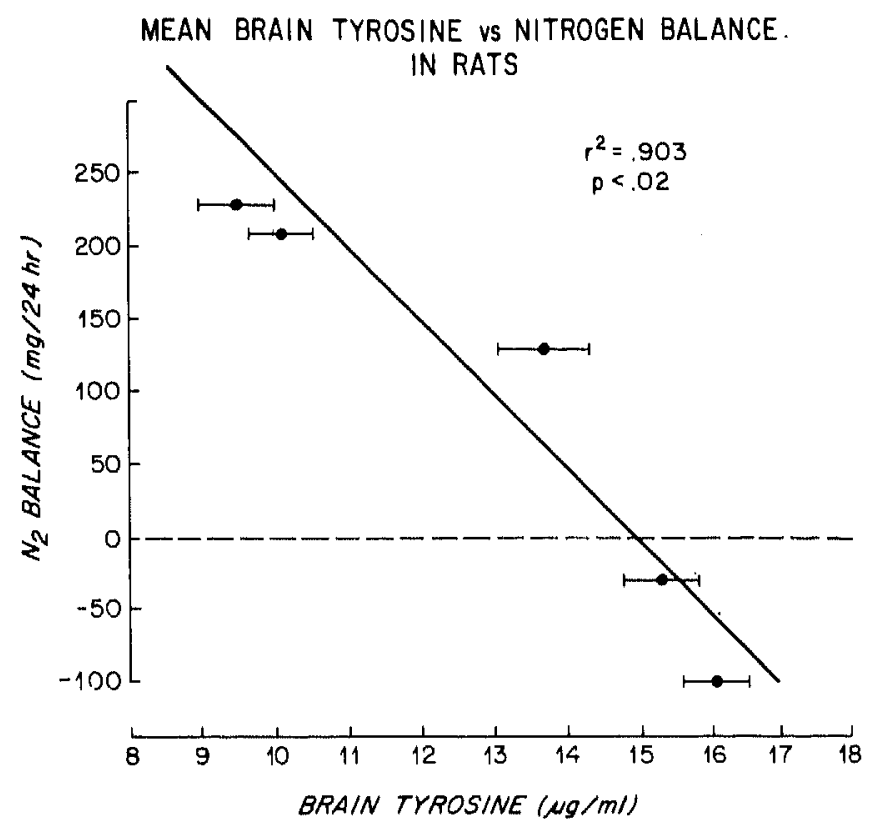

Figure 31: Mean brain tyrosine plotted against nitrogen balance in 5 groups of 10 rats each. Results are given as mean $\pm S E M$ and are highly significant. 
MEAN BRAIN TRYPTOPHAN vs NITROGEN BALANCE

IN RATS

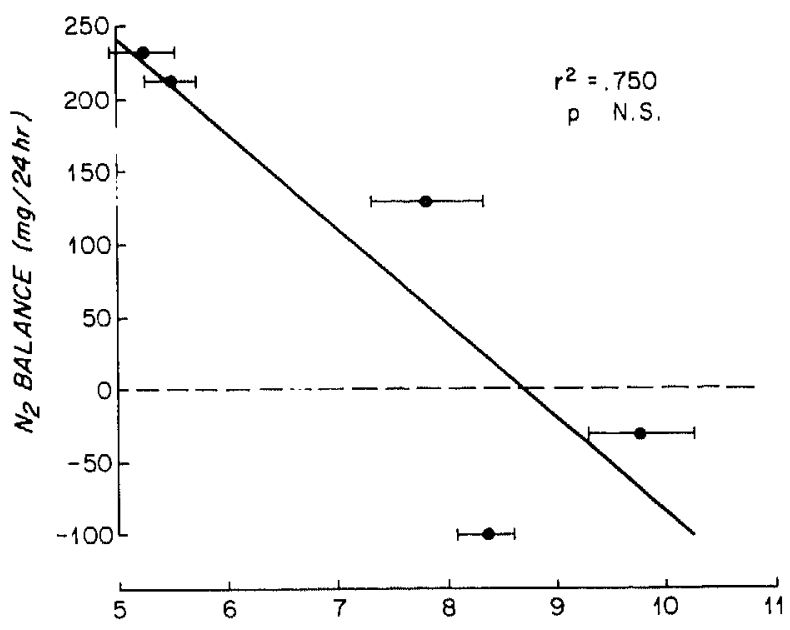

BRAIN TRYPTOPHAN $(\mu g / m I)$

Figure 32: Mean brain tryptophan plotted against nitrogen balance in rats on various amounts of nitrogen. Results are not statistically significant as analyzed by regression analysis.

MEAN BRAIN OCTOPAMINE VS NITROGEN BALANCE .

IN RATS

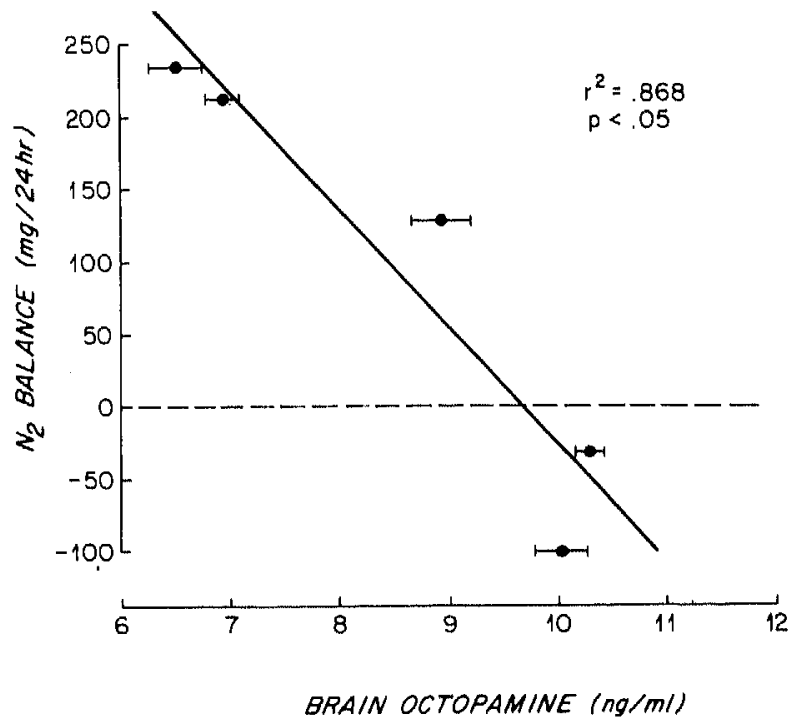

Figure 33: Mean brain octopamine plotted against nitrogen balance in 5 groups of 10 rats each. Results are given as mean \pm SEM and are significant. 
Table 11:

Mean ( \pm SEM) nitrogen balance on fourth infusion day.

\begin{tabular}{ll}
\hline \multicolumn{1}{c}{ Rats } & $\begin{array}{l}\text { N2 Balance } \\
\text { (mg/24 hrs) }\end{array}$ \\
\hline $\begin{array}{l}\text { Group I } \\
\text { Nonshunt }\end{array}$ & $196 \pm 10.2$ \\
Shunt & \\
Group II & $210 \pm 14.6$ \\
$\quad$ CS (Freamine II) & $225 \pm 22.6$ \\
HFS (F080) & $208 \pm 19.2$ \\
$\begin{array}{l}\text { Group III } \\
\quad \text { CS (Freamine II) } \\
\text { HFS (F080) }\end{array}$ & $240 \pm 26.1$ \\
\hline
\end{tabular}

Effects of nitrogen balance on plasma and brain aromatic acids In the second series of experiments nitrogen balances were consistent for all groups measured on successive days. Nitrogen balance results measured on the fourth day of hyperalimentation (table 12) were used for all calculations, as theoretically the animals were in steady state at this time. Nitrogen balance became more positive as amino acids administered per 24 hrs increased. Plasma phenylalanine, tyrosine, and tryptophan results are shown in table 13. In general, as nitrogen balance became more positive, aromatic amino acid concentrations decreased. This inverse relationship was statistically significant for plasma phenylalanine $(p<0.005)$ and tyrosine ( $p<0.001$ ), (figures $28,29,30$ ) but not for plasma tryptophan. Brain concentrations of tyrosine, tryptophan, and octopamine are presented in table 14. Brain concentrations decreased as nitrogen balance became more positive. This inverse relationship was statistically significant for brain tyrosine $(p<0.02)$ and octopamine $(p<0.05)$ (figures $31,32,33)$ but not for tryptophan.

\subsection{Discussion}

Abnormalities in plasma and brain amino acids in experimental animals with chronic end-to-side porta-caval shunts have been documented $(28,35,53,56$, 91). Similar changes occur in plasma amino acid levels in patients with chronic liver disease $(36,37$ ) (alcoholic cirrhosis, postnecrotic cirrhosis) and hepatic encephalopathy. These abnormalities include elevated plasma aromatic amino acids (phenylalanine, tyrosine and tryptophan) and decreased branched-chain amino acids (leucine, valine and isoleucine). Previous studies (chapters $2,3,4$ ) and clinical experience suggested that elevated plasma aromatic amino acid levels in hepatic encephalopathy coincided strikingly often with lysis of body cell mass and/or increased ingestion of aromatic amino acids with hepatic inability to metabolize these compounds $(84,92,93,96)$. Decreased plasma branched-chain amino acid 


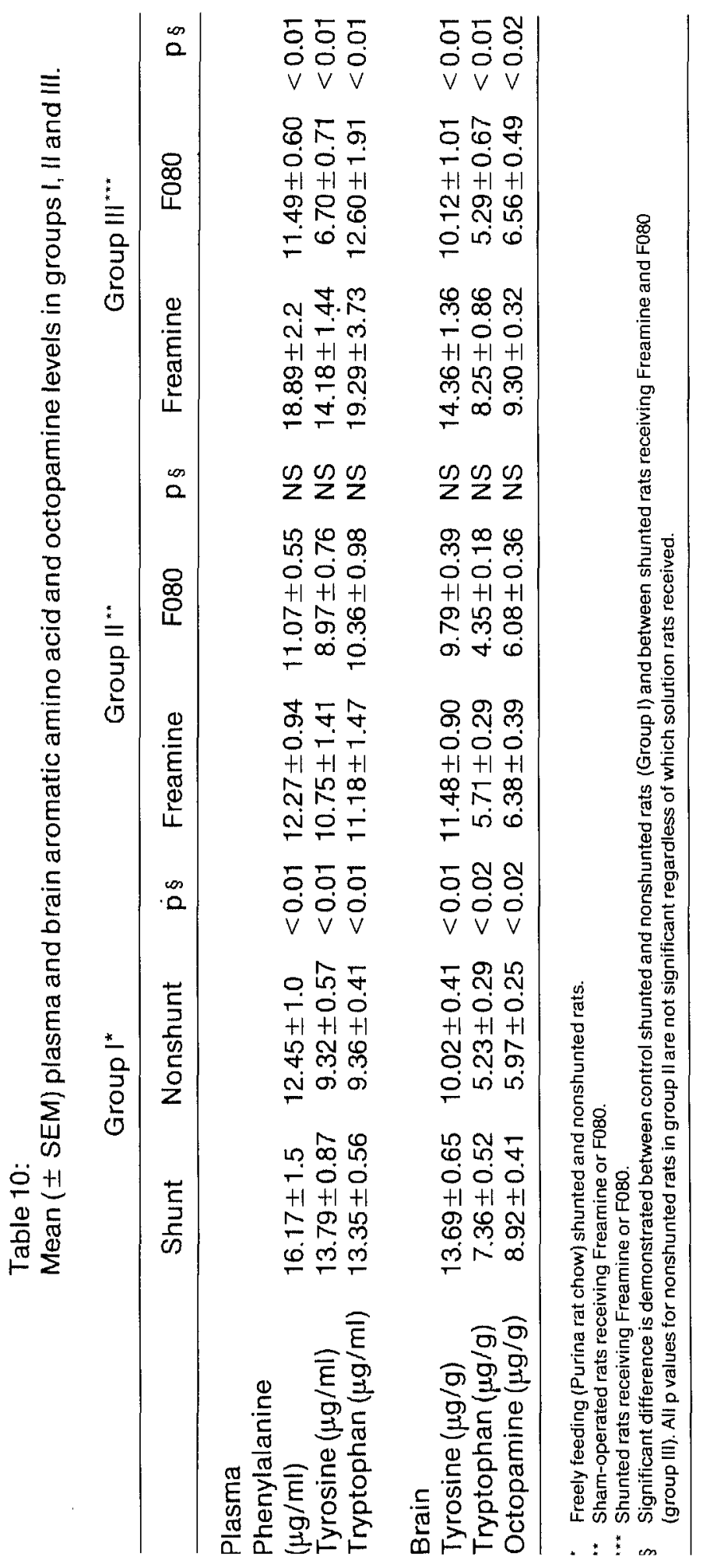


levels are thought to be secondary to hyperinsulinism encountered in hepatic failure and portal systemic shunting $(75,76,96)$. These six amino acids are neutral at blood $\mathrm{pH}$, and they compete for a common transport mechanism facilitating blood-brain barrier uptake $(41,42)$ i.e., plasma concentrations in part determine brain concentrations $(97,98,99)$. Because the aromatic amino acids are precursors of physiological neurotransmitters in the central nervous system, changes in neurotransmitter profiles might be expected to occur $(21,23,26)$ maybe causing hepatic encephalopathy $(46)$.

In the preceding chapters "normalization" of the pathological amino acid pattern described, coincided with improvement in hepatic encephalopathy.

Table 12:

Mean ( \pm SEM) net nitrogen balances on fourth infusion day (72-96 hrs).

\begin{tabular}{lccc}
\hline $\begin{array}{c}\text { Group } \\
\text { No. }\end{array}$ & $\begin{array}{c}\text { F080 Dose* } \\
\text { (g amino acid/ } \\
\text { 100 g body weight) }\end{array}$ & $\begin{array}{l}\text { N2 Balance } \\
\text { (mg/24 hrs) }\end{array}$ & p \\
\hline I & & $-109 \pm 31$ & $<0.01$ \\
II & 0.25 & $-30 \pm 15$ & $<0.01$ \\
III & 0.50 & $130 \pm 29$ & $<0.02$ \\
IV & 0.75 & $215 \pm 19$ & NS \\
V & 1.00 & $230 \pm 25$ & \\
\hline
\end{tabular}

Table 12: Results show a progression from negative to positive nitrogen balance that appears to plateau as the rats achieve $0.75 \mathrm{~g}$ amino acids. (The positive nitrogen balance achieved in group $\mathrm{V}$ at $1 \mathrm{~g}$ amino acid is not significantly higher than that achieved in group IV).

${ }^{*}$ In $23 \%$ dextrose.

Table 13:

Mean ( \pm SEM) plasma tyrosine, phenylalanine and tryptophan levels.

\begin{tabular}{clcc}
\hline Group No. & $\begin{array}{l}\text { Phenylalanine } \\
(\mu \mathrm{g} / \mathrm{ml})\end{array}$ & $\begin{array}{l}\text { Tyrosine } \\
(\mu \mathrm{g} / \mathrm{ml})\end{array}$ & $\begin{array}{l}\text { Tryptophan } \\
(\mu \mathrm{g} / \mathrm{ml})\end{array}$ \\
\hline Control & $12.45 \pm 1.0$ & $9.32 \pm 0.57$ & $9.36 \pm 0.41$ \\
I & $18.81 \pm 1.2$ & $16.62 \pm 2.6$ & $19.32 \pm 1.1$ \\
II & $16.21 \pm 1.6$ & $14.41 \pm 0.9$ & $20.61 \pm 2.1$ \\
III & $12.28 \pm 2.0$ & $9.26 \pm 1.9$ & $13.49 \pm 1.6$ \\
IV & $11.99 \pm 1.0$ & $6.59 \pm 0.81$ & $15.81 \pm 2.8$ \\
V & $11.49 \pm 0.6$ & $6.70 \pm 0.71$ & $12.60 \pm 1.91$ \\
\hline
\end{tabular}

Table 13: Note that when positive nitrogen balance is achieved, plasma concentrations of phenylalanine and tyrosine, previously elevated, return to the freely feeding control group concentration; the plasma concentration of tryptophan never returns to normal. 
Table 14:

Mean ( \pm SEM) brain tyrosine, octopamine, and tryptophan levels.

\begin{tabular}{clcl}
\hline Group No. & $\begin{array}{l}\text { Tyrosine } \\
(\mu \mathrm{g} / \mathrm{g})\end{array}$ & \multicolumn{1}{l}{$\begin{array}{l}\text { Octopamine } \\
(\mu \mathrm{g} / \mathrm{g})\end{array}$} & \multicolumn{1}{l}{$\begin{array}{l}\text { Tryptophan } \\
(\mathrm{ng} / \mathrm{g})\end{array}$} \\
\hline Control & $10.02 \pm 0.98$ & $5.97 \pm 0.25$ & $5.23 \pm 0.24$ \\
I & $16.02 \pm 1.0$ & $10.01 \pm 0.41$ & $8.34 \pm 0.41$ \\
II & $15.21 \pm 0.98$ & $10.23 \pm 0.26$ & $9.86 \pm 0.91$ \\
III & $13.67 \pm 1.4$ & $8.98 \pm 0.61$ & $7.82 \pm 1.2$ \\
IV & $10.08 \pm 0.82$ & $6.60 \pm 0.31$ & $5.48 \pm 0.46$ \\
V & $9.41 \pm 1.1$ & $6.56 \pm 0.49$ & $5.29 \pm 0.67$ \\
\hline
\end{tabular}

Table 14: All three levels return toward control values as positive nitrogen balance is achieved, starting with group III. Regression analysis shows results are significant for brain tyrosine and octopamine but not for tryptophan.

However, it is extremely difficult to obtain serial human internal or lateral ventricular central spinal fluid or brain specimens in dogs and man in order to determine if clinical hepatic encephalopathy is related to biochemical changes that may occur in the plasma and subsequently in the brain. Accordingly, these studies were undertaken to see if changes in brain aromatic amino acids and octopamine reflect plasma changes in the portal systemic shunted rat; more importantly, they were designed to determine if one could successfully manipulate and correct brain aromatic amino acidand octopamine levels with amino acid infusion techniques. From the data obtained, it would seem that by using parenteral nutrition techniques, and thus maintaining an anabolic state, one can successfully correct abnormal plasma- and brain concentrations of aromatic amino acids and at least one of their metabolic by-products octopamine.

In the foregoing experiment, excellent correlation was demonstrated between plasma and brain levels of the aromatic amino acids, tyrosine and tryptophan, independent of route of administration and whether or not animals were shunted. Significant differences in plasma and brain aromatic amino acids and brain octopamine were demonstrated only in shunted rats as aromatic intake varied. Thus, in freely feeding shunted rats as well as in shunted rats in group 3, receiving Freamine II, these levels were significantly higher than in shunted rats receiving F080.

However, these levels were not significantly different in group 2 nonshunted rats regardless of which amino acid infusion was used, and therefore concentrations were independent of aromatic amino acid intake.

Concentrations of aromatic amino acids in group 2 were essentially the same as in freely feeding nonshunted rats in group 1 . It would seem that the normal liver can metabolize a large quantitative range of aromatic amino acids. Shunted rats, on the other hand, cannot tolerate increased amounts of ingested aromatic amino acids; excess intake results in an abnormal 
tryptophan, and octopamine. These levels can be successfully reduced to normal in both plasma and brain by maintaining the shunted rat in positive nitrogen balance and infusing glucose and an amino acid mixture high in branched-chain amino acids and low in aromatic amino acids.

The contribution of the anabolic state was investigated in the second part of these experiments, after calculation of data in the group 3 animals in the first part suggested that plasma aromatic amino acids concentrations were inversely proportional to nitrogen balance (i.e., they were lower with greater nitrogen retention). The data obtained by varying nitrogen intake in the second series of experiments from 0 to $1.0 \mathrm{~g} / 100 \mathrm{~g}$ body weight clearly show that plasma phenylalanine and tyrosine and brain tyrosine and octopamine are inversely proportional to nitrogen balance: the greater the anabolic state, the lower the plasma concentrations of these aromatic amino acids, whose fate is presumably intracellular.

The highly significant correlation between nitrogen balance and plasma phenylalanine and tyrosine and brain tyrosine and octopamine supports the concept of catabolism-induced hepatic encephalopathy in the presence of severe pre-existing liver disease. Lysis of body cell mass floods the circulation with amino acids, of which the aromatic amino acids cannot be sufficiently metabolized by the liver. Consequently, aromatic amino acids accumulate. As nitrogen balance becomes positive, this sequence of events is reversed channelling aromatic amino acids back into protein synthesis. This process may be enhanced by the addition of extra branched-chain amino acids, normalizing plasma amino acid pattern and presumably amino acid pools, in such a way that a more balanced substrate pattern may be achieved for protein synthesis.

In addition, Escourrou et al. have recently shown that the administration of branched-chain amino acids alone, at any given level of nitrogen balance, not only decreases the efflux of aromatic amino acids from skeletal muscle, but also normalizes the plasma tyrosine/brain tyrosine concentration ratio (100).

Brain and plasma tryptophan concentration did not correlate as well with nitrogen balance. This is not surprising, as in the acute rapidly changing state, free tryptophan appears more available for transport across the bloodbrain barrier; in addition, it is influenced by various other factors, including insulin, plasma glucose and non esterified fatty acids $(47,49,50,51,52,101)$. In these experiments, only total tryptophan was measured, as sufficient amounts of plasma were not available for the measurement of free tryptophan as well. Thus, the evidence to date suggests that determinants of plasma and brain aromatic amino acid concentrations in liver disease include exogenous intake, nitrogen balance, and at a given level of nitrogen balance, the amounts of branched-chain amino acids ingested.

\subsection{Summary}

In an effort to determine the sum of the factors influencing the plasma- and brain concentrations of aromatic amino acids in rats with liver disease, rats with end-to-side porta-caval shunts and their sham-operated controls were 
placed on various oral and intravenous diets by the technique of parenteral nutrition.

1. In sham-operated animals with normal hepatic function, the source of amino acids and their composition appeared to play little role in the plasma and brain aromatic amino acids and a derivative of brain tyrosine:

octopamine. After end-to-side porta-caval shunt, however, plasma- and brain concentrations of aromatic amino acids were responsive to exogenous intake in the presence of hepatic impairment.

2. In a group of rats with end-to-side porta-caval shunt and presumed hepatic impairment, graded increments of amino acids were given with isocaloric hypertonic dextrose by the techniques of parenteral nutrition. When the animals achieved positive nitrogen balance, there were decreased levels in plasma and brain of the aromatic amino acids, phenylalanine, tyrosine and octopamine. A clear statistical relationship between plasma and brain tryptophan and nitrogen balance could not be established.

3. The results suggest that in animals with hepatic impairment secondary to end-to-side porta-caval shunt, both exogenous intake and the level of catabolism (nitrogen balance) influence plasma and brain aromatic amino acids. 


\section{Chapter 6:}

\section{Leucine metabolism and porta-caval shunt in the rat}

\subsection{Introduction}

The plasma amino acid pattern in hepatic insufficiency and hepatic encephalopathy includes elevated phenylalanine, methionine and tyrosine, as well as a normal or slightly increased tryptophan $(23,28,34,35,36,37,46,74)$. The branched-chain amino acids, valine, leucine and isoleucine, which compete for entry across the blood-brain barrier with the three neutral aromatic amino acids, phenylalanine, tyrosine and tryptophan, are almost always reduced in plasma. Normalization of this plasma amino acid pattern is associated with improvement in neurological status in dogs (chapter 2) and in man (chapter 4).

In addition, infusions of branched-chain amino acids in rats with experimentally induced chronic or acute hepatic encephalopathy, decreased brain serotonin content (52) and increased norepinephrine content (100) resulting in a normalized brain neurotransmitter profile. This focused our attention on the decreased plasma branched-chain amino acid levels. The liver cannot catabolize branched-chain amino acids to a significant degree and Miller (60) has shown that nonhepatic tissues can. There is no agreement however as to how peripheral tissues can decrease plasma branched-chain amino acid levels.

The purpose of this study is if, where and how the peripheral tissues can decrease plasma branched-chain amino acid levels in rats with porta-caval shunts compared to control rats.

\subsection{Materials and methods}

Female Sprague-Dawley rats weighing between 200-250 grams were anesthetized with ether and a porta-caval anastomosis was performed according to the technique recently described by Funovics et al (93). Patency of the shunt was confirmed at autopsy. Sham operated rats of the same age, sex, strain and weight served as controls. All animals were sacrificed one month after the operation when the metabolic effects of surgery had stabilized, and were allowed Purina Chow and water ad libitum until that time. Animals were sacrificed by decapitation between 10:00 and 11:00 hours.

Kidney and muscle incubation experiments using L-leucine (1-C $C^{14}$ ) The first series of experiments was performed on carefully dissected diaphragm quarters and kidney slices (containing both medulla and cortex) made with a Stadie Riggs Tissue Slicer. These tissue samples were taken from both fed and fasted shunts and controls. The tissue weight was consistently maintained between 30 and $50 \mathrm{mg}$ since it was observed in preliminary experiments that $\mathrm{CO}_{2}$ production was limited by the rate of diffusion of $\mathrm{O}_{2}$ and metabolites in larger pieces compared to small pieces. 
After weighing, the tissue was immediately placed in $5 \mathrm{ml}$ of oxygenated Krebs-Ringer Bicarbonate buffer $\mathrm{pH} 7.3$ with $5 \mathrm{mM}$ glucose added and incubated with L-leucine (1-C $\left.{ }^{14}\right)$ (NEV-169) S.A. of .25 mCi/mmole at a concentration of $0.1 \mathrm{mM}$ leucine. The reaction was carried out for 90 minutes at $37^{\circ} \mathrm{C}$ in a constant temperature vigorously shaking bath. $\mathrm{C}^{14}$ leucine incorporation into ${ }^{14} \mathrm{CO}_{2}$ and trichloroacetic acid (TCA) precipitable protein were measured according to the method of Odessey and Goldberg (96). Results were calculated in terms of nmoles $/ \mathrm{mg} / \mathrm{hr}$ for ${ }^{14} \mathrm{CO}_{2}$ and radioactive TCA precipitable protein.

Adipose tissue incubation experiments with L-leucine- $C^{14}(U)$ In a second series of experiments, $30-50 \mathrm{mg}$ pieces of carefully dissected retroperitoneal adipose tissue was excised from both fed and fasted shunts and controls. After weighing, the fat tissue was immediately placed in $2 \mathrm{ml}$ of oxygenated Krebs-Ringer Bicarbonate $\mathrm{pH} 7.3$ with $5 \mathrm{mM}$ glucose added and incubated with $1.0 \mathrm{mCi} / \mathrm{mmole}$ of L-leucine $\mathrm{C}^{14}$ - (U) NEC-279 at a concentration of $0.1 \mathrm{mM}$ leucine. After the reaction was allowed to run. for 3 hours in a metabolic shaker at $37^{\circ} \mathrm{C}$ the adipose tissue was hydrolysed and extracted according to the method described by Goodman (103). ${ }^{14} \mathrm{C}$ incorporation into ${ }^{14} \mathrm{CO}_{2}$ and anhydrous diethyl ether soluble fatty acid were determined according to Goodman and calculated in terms of ng-atoms $/ \mathrm{mg} / \mathrm{hr}$.

\subsection{Results}

Rats with and without porta-caval shunts ate the same amounts of food and gained the same amount of weight.

The results of the muscle incubation studies with C14-leucine (23) are presented in table 15. No significant differences were observed in either the fed or 24 hrs fasted state both with controls and shunts, in the amount of $\mathrm{C}^{14} \mathrm{O}_{2}$ production. In repeated experiments, however, it was noted that the

Table 15: L-Leucine (1-C 14$)$ metabolism in muscle.

\begin{tabular}{|c|c|c|c|c|c|c|}
\hline & \multicolumn{2}{|c|}{$\mathrm{C}^{14} \mathrm{O}_{2}$ Production } & $\frac{\mathrm{nmoles}}{\mathrm{mg} / \mathrm{hr}}$ & \multicolumn{3}{|c|}{$\mathrm{C}^{14}$ Protein incorporation $\frac{\mathrm{nmoles}}{\mathrm{mg} / \mathrm{hr}}$} \\
\hline & Controls & Shunts & $p$ & Controls & Shunts & $p$ \\
\hline FED & $.0244 \frac{ \pm}{(5)} .0085$ & $.0214 \frac{ \pm}{(6)} .0017$ & n.s. & $.0093 \frac{ \pm}{(5)} .0018$ & $.0123 \pm . .0012$ & 2 n.s. \\
\hline $\begin{array}{l}\text { 24-hr } \\
\text { FASTED }\end{array}$ & $.0159 \pm \frac{ \pm}{(5)} .0026$ & $.0122 \pm \frac{ \pm}{(7)} .0080$ & n.s. & $.0084 \underset{(6)}{ \pm .0010}$ & $.0080+\frac{.0009}{(7)}$ & 9 n.s. \\
\hline$p$ & n.s. & n.s. & & n.s. & $<.02$ & \\
\hline
\end{tabular}


shunts produced consistently less $\mathrm{C}^{14} \mathrm{O}_{2}$ than controls in both the fed and fasted state although the differences were never significant. In the fed group, the shunted rats were $89 \%$ of control (Shunts: $0.0214 \pm 0070$; controls: $0.0244 \pm .0085 \mathrm{nmoles} / \mathrm{mg} / \mathrm{hr}$ ) while in the fasted group the shunts were $77 \%$ of control (shunts $.0122 \pm .008$; control $0.0159 \pm .0026 \mathrm{nmoles} / \mathrm{mg} / \mathrm{hr}$ ). When comparing the fed and fasted states, a decrease in $\mathrm{C}^{14} \mathrm{O}_{2}$ production was noted in the fasted shunts which were $57 \%$ of the fed shunts. This decrease was not significant. The fasted normals were $65 \%$ of the fed normals, this decrease was likewise nonsignificant.

No significant differences were observed between shunts and controls in either the fed or fasted state in the extent of $\mathrm{C}^{14-l e u c i n e}$ incorporation into TCA - precipitable protein. In the fed group, the shunts showed a nonsignificant $37 \%$ increase (shunts $0.0123 \pm .0012$; controls $.0093 \pm .0018$ $\mathrm{nmoles} / \mathrm{mg} / \mathrm{hr}$ ) over the controls and in the fasted group, the shunts were $95 \%$ of controls (shunts $.0080 \pm .009$; controls $.0084 \pm 0010 \mathrm{nmoles} / \mathrm{mg} / \mathrm{hr}$ ). A significant decrease in protein incorporation was observed in the fasted shunts, which showed $65 \%$ of the protein incorporation in the fed shunts (fed: $0.0123 \pm .0012$; fasted: $0.0080 \pm .0090$ ) with $p<.02$. No significant difference was noted between the fasted and fed controls.

\section{Kidney incubation studies}

The results of the kidney incubation experiments with $\mathrm{C}^{14}$-leucine are demonstrated in table 16 . No significant differences were observed between shunts and controls in the amount of $\mathrm{C}^{14} \mathrm{O}_{2}$ produced from $\mathrm{C}^{14}$-leucine in kidney slices in either the fed or fasted state. In the fed group, the shunts showed a slight decrease in $\mathrm{C}^{14} \mathrm{O}_{2}$ production. The fed shunts showed $78 \%$ $\mathrm{C}^{14} \mathrm{O}_{2}$ as the fed controls (shunts: $0.0208 \pm .004$; controls: $0.0265 \pm .0045$ nmoles/mg/hr).

The difference in $\mathrm{C}^{14} \mathrm{O}_{2}$ production between fed and fasted nonshunted controls was non-significant. The fasted controls showed a slight decrease with $83 \%$ of the $\mathrm{C}^{14} \mathrm{O}_{2}$ production of the fed controls. The fasted shunts, however, showed a highly significant increase in $\mathrm{C}^{14} \mathrm{O}_{2}$ production compared with fed shunts. The fasted shunts $\mathrm{C}^{14} \mathrm{O}_{2}$ production was $206 \%$ of the fed

Table 16: L-Leucine (1-C $\left.{ }^{14}\right)$ metabolism in kidney slices.

\begin{tabular}{|c|c|c|c|c|c|c|}
\hline & \multicolumn{2}{|c|}{$\mathrm{C}^{14} \mathrm{O}_{2}$ Production } & $\frac{\mathrm{nmoles}}{\mathrm{mg} / \mathrm{hr}}$ & \multicolumn{3}{|c|}{ C14 Protein incorporation $\frac{\mathrm{nmoles}}{\mathrm{mg} / \mathrm{hr}}$} \\
\hline & Controls & Shunts & $p$ & Controls & Shunts & $p$ \\
\hline FED & $.265 \pm .0045$ & $.0208 \frac{ \pm}{(5)} .0040$ & n.s. & $.0152 \frac{ \pm}{(5)} .0030$ & $.0138 \pm .0033$ & n.s. \\
\hline $\begin{array}{l}\text { 24-hr } \\
\text { FASTED }\end{array}$ & $.321 \pm .0033$ & $.0429 \pm .0020$ & n.s. & $.0049 \frac{ \pm}{(8)} .0070$ & $.0048 \pm .0006$ & n.s. \\
\hline$p$ & n.s. & $<.001$ & & $<.01$ & $<.01$ & \\
\hline
\end{tabular}


shunts (fasted: $.0429 \pm .0020$; fed: $.0208 \pm .004$ ) with $p<.001$.

There were no significant differences observed in the amount of $\mathrm{C}^{14}$-leucine incorporated into TCA-precipitable protein between the shunts and controls in either the fed or fasted state. When either the shunts or normals are fasted there is a very significant decrease in $\mathrm{C}^{14}$-leucine incorporation into TCA precipitable protein. The fasted normals incorporated $23 \%$ as much $\mathrm{C}^{14}$ leucine into protein as the fed normals (fasted: $.0049 \pm .0070$; fed: 0152 \pm .0030 ) with $\mathrm{p}<.01$. The fasted shunts incorporated $35 \%$ as much $\mathrm{C}^{14}$ leucine into protein as the fed shunts (fasted: .0048 \pm .006 ; fed: .0138 \pm .0033 ) with $p<.01$.

Adipose tissue incubations with $\mathrm{C}^{14}$-leucine A significant increase was observed in the amount of $\mathrm{C}^{14}$-leucine incorporated into diethyl ether soluble fatty acids in the rats receiving a porta-caval anastomosis as compared to control animals undergoing a sham-operation in both the freely feeding and $24 \mathrm{hr}$ starved groups. These results are shown in table 17. In the fed experiments, a significant increase of $77 \%(p<.02)$ in $\mathrm{C}^{14}$-leucine incorporation was observed in the shunts (shunts: $0.005 \pm 0.007$, controls: $0.031 \pm 0.005$ ). In the starved experiments, an even greater and highly significant increase of $249 \%$ was seen in the shunted animals (shunts: $0.0863 \pm .011$; controls: $0.0247 \pm 0.0044, p<$ .001). No significant differences were observed between fed and fasted controls in the amount of $\mathrm{C}^{14-l e u c i n e ~ i n c o r p o r a t i o n, ~ a l t h o u g h ~ t h e ~ s t a r v e d ~}$ group showed a slight but non-significant $20 \%$ elevation. The fasted shunts, however, showed a significant increase of $57 \%(p<.05)$ compared to controls.

The results of the $\mathrm{C}^{14}$-leucine oxidation studies in adipose tissue are also displayed in table 17. There were no significant differences observed between shunts and controls in either the fed or 24 hour starved experiments. The starved shunts and controls, however, showed similar significant elevations in $\mathrm{CO}_{2}$ production compared with the fed shunts and controls. Starved controls showed a $69 \%$ increase over fed controls and starved

Table 17: L-Leucine-C ${ }^{14}(\mathrm{U})$ metabolism in adipose tissue.

\begin{tabular}{lcccccc}
\hline & \multicolumn{2}{c}{$\begin{array}{c}{ }^{14} \mathrm{CO}_{2} \text { Production } \\
\text { ng-atoms/mg/hr }\end{array}$} & & \multicolumn{3}{c}{$\begin{array}{c}\text { C'14 Production } \\
\text { into fat ng-atoms } / \mathrm{mg} / \mathrm{hr}\end{array}$} \\
\hline Controls & Shunts & $\mathrm{p}$ & Controls & Shunts & $\mathrm{p}$ \\
\hline FED & $\begin{array}{c}.093 \pm .011 \\
(18)\end{array}$ & $\begin{array}{c}.089 \pm .007 \\
(16)\end{array}$ & n.s. & $\begin{array}{c}.031 \pm .005 \\
(18)\end{array}$ & $\begin{array}{c}.055 \pm .007 \\
(16)\end{array}$ & $<.02$ \\
$24-\mathrm{hr}$ & $.157 \pm .011$ & $.167 \pm .016$ & n.s. & $.0247 \pm .0044$ & $.0863 \pm .011<.001$ \\
FASTED & $(10)$ & $(10)$ & & $(10)$ & $(8)$ & \\
p & $<.001$ & $<.001$ & & n.s. & $<.05$ \\
\hline
\end{tabular}


shunts a $88 \%$ increase over fed shunts. Student's t-tests showed $p<.001$ for both groups.

\subsection{Discussion}

Sherwin (75) and Munro (76) have associated the low branched-chain amino acid levels with the state of hyperinsulinism, which exists in cirrhotic patients with portal systemic shunting $(75,100)$, dogs with porta-caval shunts $(105)$ and rats with porta-caval anastomosis after oral glucose loads (100). Their hypothesis is that branched-chain amino acids are in some way removed by muscle tissue under influence of insulin as it occurs in the human forearm when insulin is injected (107).

Over the past years, much evidence has accumulated that a close relationship exists between insulin levels and branched-chain amino acid levels $(108,109,110)$. Accordingly, the state of chronic hyperinsulinism in man or experimental animals with hepatic insufficiency, and porta-caval shunting may well be associated with low branched-chain amino acid levels. The exact mechanism however remains to be elucidated. The branched-chain amino acids are mainly catabolized by peripheral tissues contrary to the other essential amino acids which can be catabolized by the liver to a significant degree (60). We repeatedly failed to show increased leucine catabolism in diaphragms of shunted rats both in the fed and fasted state, which is in agreement with the findings of Goldberg (102): the fed state, associated with high insulin levels is characterized by a low rate of oxidation of branchedchain amino acids and fatty acids as compared to starvation which is associated with low insulin levels.

A trend towards increased leucine incorporation into muscle protein was observed in some experiments in fed shunted rats. In subsequent experiments, we measured potassium spaces which were not significantly different in shunted rats and controls. In addition, increased net protein synthesis would tend to decrease amino acid levels according to the composition of protein rather than cause isolated decreases in branchedchain amino acid levels. Finally, free amino acid pools cannot contain significant amounts of branched-chain amino acids to explain the observed plasma amino acid patterns.

Subsequent experiments with universally labelled leucine indicated that $\mathrm{C}^{14} \mathrm{O}_{2}$ production and label incorporated into muscle protein did not differ significantly in fed shunted rats and controls. The adipose tissue incubations however, showed significantly increased incorporation of carbon label derived from $\mathrm{C}^{14} \mathrm{~L}$-leucine into fatty acids in the shunted rats as compared to controls both in the fed and fasted state.

The old concept of leucine being exclusively ketogenic was in agreement with the work of Feller (112) who observed that the biosynthetic activity of fat with regard to the incorporation of the carbon skeletons of amino acids is by far the greatest for leucine. Isoleucine and valine skeletons were equally incorporated into fatty acid albeit in smaller amounts, despite the fact that valine is considered to be exclusively glucogenic.

The present data indicate that increased leucine incorporation into fatty acid 
may be operative in decreasing leucine levels in rats with portal systemic shunts. It is unclear if this mechanism is equally applicable to isoleucine and valine. Recent data from Kipnis' laboratory (111) and older data from Feller (112) indicate that the classification of amino acids as either ketogenic or glucogenic or both may not be true in terms of overall body metabolism, so that predictions based on this classification may be erratic.

Felig suggested (110) that increased branched-chain amino acid levels in obese people constitute the feedback signal for the pancreas to secrete increased amounts of insulin. The reverse does not seem to be true: low branched-chain amino acid levels in rats with porta-caval shunts do not suppress insulin secretion. The presented data suggest that adipose tissue may play a role in the homeostasis of leucine. Increased leucine levels observed in obesity may indicate that the postulated insulin resistance of adipose tissue with regard to glucose and fatty acids includes leucine as well.

\subsection{Summary}

Decreased plasma branched-chain amino acid levels have been repeatedly reported in patients and animals with hepatic failure. In order to investigate this phenomenon, the fate of labelled leucine was studied in in vitro incubation of pieces of tissue obtained from fasted or fed rats which were subjected to porta-caval shunt or to sham-operation four weeks previously. Incorporation of labelled leucine into protein, combustion to ${ }^{14} \mathrm{CO}_{2}$, and labelled leucine in free pools were measured in diaphragm, and kidney slices. No significant differences were found between rats subjected to porta-caval shunt or sham-operation. Only when pieces of adipose tissue were incubated in the same manner, a significant increase in incorporation of leucine derived ${ }^{14} \mathrm{C}$ into fatty acid was observed in rats with porta-caval shunts. The data indicate that increased incorporation of leucine derived carbon into fatty acid may contribute to the decreased leucine levels in rats with porta-caval shunts. The magnitude of this effect remains to be determined, as well as the mechanism operative with regard to isoleucine and valine. 


\section{Chapter 7:}

Comprehensive interpretation of the pertinent experimental data.

\subsection{Metabolic abnormalities in hepatic encephalopathy.}

A characteristic amino acid pattern in cirrhosis and hepatic encephalopathy has been repeatedly reported, including increased plasma levels of phenylalanine, tyrosine, methionine and glutamine and decreased plasma levels of branched-chain amino acids and threonine. It now appears from our data (chapters 2 and 4 ) and from the literature that plasma branched-chain amino acid levels may be in the normal range in fulminant hepatitis and in dogs with hepatic encephalopathy subsequent to porta-caval shunt. Record e.a. (57) even suggested that decreased plasma branched-chain amino acid levels may have positive prognostic significance. In hepatic encephalopathy in chronic liver disease however, plasma amino acid levels in general are only moderately elevated compared to fulminant hepatitis, and plasma branchedchain amino acid levels are decreased. In all forms of hepatic encephalopathy, hyperaminoacidemia is noted, which is most striking in fulminant hepatitis. The enormous increments in glutamine levels are not always appreciated, contributing most significantly to hyperaminoacidemia. The mechanism involved in the dissociation of plasma levels of branchedchain amino acids and threonine, and most other amino acids, especially phenylalanine, tyrosine, methionine and glutamine, has been subject to speculation (76). The rises in levels of methionine, phenylalanine and tyrosine are not surprising, as they are principally catabolized by the liver and cannot be catabolized peripherally. It is not clear, however, why plasma concentrations of the branched-chain amino acids are decreased. Branchedchain amino acids are principally catabolized peripherally independent of hepatic function, and while this may explain why plasma branched-chain amino acids are not raised, it does not explain the decrease.

Sherwin et al (75) and Munro et al (76) have associated the low plasma branched-chain amino acid concentrations with hyperinsulinism encountered in cirrhotic patients with spontaneous or surgical portal systemic shunting $(75,104)$. According to their hypothesis, the principal site of degradation of the branched-chain amino acids is muscle. There is considerable support for the possible inverse relationship between insulin levels and branched-chain amino acid levels: increased uptake of branchedchain amino acids occurs in the human forearm after insulin administration (107); in uncontrolled diabetes, plasma branched-chain amino acids are raised (108); in starvation, branched-chain amino acids are initially increased, corresponding to a decrease in insulin; after feeding, insulin increases and plasma branched-chain amino acids are low (109). In our dog studies (chapter 2 and 3 ) we confirmed the inverse relationship between insulin levels and plasma branched-chain amino acid levels. At 1 and 4 weeks after porta-caval shunt, dogs exhibited substained rises in insulin levels after arginine infusion tests coinciding with significant 
decreases in branched-chain amino acid levels. In hepatic encephalopathy however, insulin levels dropped to normal after arginine infusion whereas plasma branched-chain amino acid concentrations were in the normal range (table 4 , figures 4 and 17 ).

Increased uptake and incorporation of branched-chain amino acids into muscle, however, does not, adequately explain the isolated decrease in branched-chain amino acid levels, because the pattern of decrease would be expected to reflect the amino acid composition of muscle protein which it does not. Furthermore, cirrhotic patients generally show signs of muscle wasting, rather than increased muscle mass. Interstitial and intracellular muscle pools are small, compared to amino acids in muscle protein and visceral protein, and do not store significant amounts of amino acids. Thus, increased degradation by muscle is the only possibility left to explain the decreased plasma branched-chain amino acid levels if muscle would be the only tissue catabolizing branched-chain amino acids. Odessey and Goldberg, however, showed in in vitro muscle incubations, that muscle (hemidiaphragm) degrades more branched-chain amino acids in the starved state, accompanied by a low insulin level, than in the fed state, associated with a high insulin level (102). This suggests, that factors other than muscle degradation of the branched-chain amino acids may be responsible for the decreased plasma branched-chain amino acids seen in hepatic insufficiency. In order to investigate this phenomenon, we incubated hemi-diaphragms from normal and shunted rats in vitro in Krebs-Ringer solution with $\mathrm{C}^{14}$ leucine as described in chapter 6 . No significant differences in free-pools, combustion or incorporation into protein could be observed, suggesting that if hyperinsulinism caused the decrease in branched-chain amino acid levels, it did not do so by increased degradation by muscle. Other sites of branchedchain amino acid degradation are possible.

Insulin stimulates uptake of leucine into fatty acids in adipose tissue (103). Thus, in addition to incubating muscle tissue and kidney slices, we incubated pieces of adipose tissue from normal and porta-caval shunted rats with $\mathrm{C}^{14}$ leucine and observed an increased incorporation of $\mathrm{C}^{14}$-leucine into fat in the shunted rats (table 17). We did not measure fat DNA or total protein content, but as the shunted rats were not leaner and as there is no reason to assume that differences in cellularity exist, the shunted rats very likely incorporate more leucine into fat, than do their sham-operated controls. As adipose tissue is a large organ, this phenomenon may be responsible for the low leucine levels observed in shunted rats. Whether this phenomenon applies to valine and isoleucine as well, is uncertain. Nor is it possible to estimate from the data obtained, the magnitude of this effect in vivo.

In summary, there is a very constant inverse relationship between insulin levels and branched-chain amino acid levels, suggesting causality but not proving it, and if this is the case, the mechanism may operate through adipose tissue. Because insulin and glucagon are considered to exert a bihormonal control (89) in glucose homeostasis, these metabolic considerations are incomplete without knowledge of glucagon levels. Whereas the hyperinsulinemia seen in patients and in experimental animals 
(chapter 3) is modest (104), glucagon levels often rise two- to tenfold, especially when the liver, the principal target organ for glucagon, fails after porta-caval shunt in dogs (chapters 2 and 3 ) and in cirrhotic man (113). The pathogenesis of hyperinsulinism and hyperglucagonism has been subject to much debate. It has been claimed $(114,115)$, that clearance of insulin by the liver is decreased when liver disease and spontaneous or surgically induced portal systemic shunting occurs. Only a minor part of the insulin secreted by the pancreatic islet however is broken down by the liver and differences in immunoreactive insulin concentrations in portal or systemic blood may be largely explained by the dilution that occurs (114).

Hyperglucagonism in hepatic encephalopathy is so extreme, that a large part must be due to hypersecretion (116). Catecholamines (78) are reported to elicit glucagon secretion, but indirect evidence exists that catecholamine levels are decreased in encephalopathy (86). The autonomic nervous system probably modulates glucagon secretion directly, but the question remains what stimulates the autonomic nervous system. In addition, no changes in glucose levels were observed, so it seems likely, that glucagon levels are caused by changes in glucose levels. Glucagon however, is intimately involved in the metabolism of amino acids. The hyperaminoacidemia that was noted in encephalopathy might directly or indirectly function as a powerful secretagogue. Hyperglucagonemia itself induces insulin secretion. One might argue however that glucose production in the liver induced by glucagon also secundarily releases insulin. When liver function deteriorates, glucose production diminishes, resulting in lower insulin levels, in turn resulting in increased branched-chain amino acid levels.

The following sequence of events may be proposed: in liver failure a characteristic amino acid pattern is observed; a steady state may be reached for a long time at the expense of increased concentrations of those amino acids that rely for their homeostasis on the liver and on hormones (glucagon), that induce reactions in the liver in which those amino acids are involved. Both phenomena serve to boost the failing liver to optimal capacity. When liver function deteriorates even further, extremely elevated concentrations of aromatic amino acids, methionine, glutamine and glucagon are observed and hepatic encephalopathy may ensue. Failure to catabolize these amino acids may lead to reduced glucose output. The decrease of previously elevated insulin levels occurring in hepatic encephalopathy (chapter 4) may be viewed as a reflection of this reduced glucose output and may be related to normalization of previously decreased plasma-branchedchain amino acid levels. This explains why in dogs subjected to porta-caval shunts, the

$\frac{\text { valine }+ \text { isoleucine }+ \text { leucine }}{\text { tyrosine + phenylalanine }}$ ratio does not decrease further when encephalopathy supervenes, and is only a crude indicator for hepatic encephalopathy. Hepatic encephalopathy may also occur when exogenous "bad" amino acids are administered (meat, blood) or hyperaminoacidemia occurs when the circulation is flooded with amino acids derived from breakdown of endogenous protein after a metabolic insult (sepsis, diuretics etc..). 
It is unclear, in how far hepatic function itself deteriorates under these circumstances. It is conceivable that hepatic function per se does not deteriorate in exogenous coma due to for instance increased ingestion of protein, so that hyperinsulinism and decreased plasma branched-chain amino acid levels are sustained.

\subsection{Amino acid - glucose infusions}

Effect

Until recently, current practice in the treatment of hepatic encephalopathy has always been protein restriction, and it has been repeatedly demonstrated that ingestion of too much protein aggravated or even precipitated hepatic encephalopathy in experimental animals and man. Our experiments in dogs (chapter 2) have shown that F080 can be administered in sufficient quantities to cover protein requirements, at the same time achieving improvement in neurological state. This may also apply to man as is suggested in chapter 4. No toxic side effects were noted in dogs (chapter 2), rat (chapter 5) and man (chapter 4).

Mechanism

It is difficult to determine the mechanism operative in the beneficial effect of F080, because the infusion of F080 elicits a multitude of metabolic events, many of which may play a role. The addition however of branched-chain amino acids and withdrawal of the largest part of aromatic amino acids is crucial as isocaloric isonitrogenous amounts of Freamine II (53) and isocaloric amounts of the glucose - amino acid mixture containing half the amount of Freamine II (chapter 2) precipitated coma or aggravated encephalopathy almost without exception. The mechanism may involve at least three different aspects:

1. Hepatotrophic effect. Attention has focused recently on hepatotrophic factors $(120,121,122,123,124,125)$ promoting hepatic regeneration. Among others, insulin, glucagon, epidermal growth factor and factors derived from the liver itself have been named as possible candidates. It is very likely that insulin plays a contributory role in achieving regeneration (117). Nutrition elicits pancreatic insulin secretion which may enhance liver regeneration and thus liver function.

2. Normalization of the plasma amino acid pattern. Normalization of the plasma amino acid pattern changes the branched-chain amino acid/aromatic amino acid ratio and therefore, influences the pattern of uptake of the neutral amino acids into the brain. Administration of the branched-chain amino acids in animals with chronic hepatic insufficiency following porta-caval shunt, decreases brain tryptophan within 4 hours (32). In animals with acute hepatic failure following complete hepatic devascularization, administration of branched-chain amino acids increases brain norepinephrine and decreases brain octopamine. No data however are available concerning the effect of the administration of branched-chain amino acids on encephalopathy. Nor 
should the effect of branched-chain amino acids be viewed solely as "normalization" of plasma amino acid pattern. Branched-chain amino acids are of all amino acids the most powerful pancreatic $\beta$ cell secretagogues $(118,119)$. According to Maria Buse (126), leucine plays a "pivotal" role in promoting protein synthesis. Accordingly, a systemic effect of the branchedchain amino acids cannot be separated from a local effect on the blood-brain barrier.

3. Achievement of anabolism. This systemic effect may be translated in terms of anabolism. Several data suggest that the dissociation in amino acid pattern and -pools referred to in chapters $2,3,4$ and 5 occurs especially in states where body protein is broken down, or in situations where this dissociation is enhanced by exogenous administration of protein. We mentioned in chapter 4 , that patients in hepatic encephalopathy were in negative nitrogen balance. Dogs in hepatic encephalopathy even showed extremely negative nitrogen balances, coinciding with very low insulin/glucagon molar ratios (chapter 2 and 3 ). In rats, plasma aromatic amino acid concentrations in plasma and brain correlated well with nitrogen balance (chapter 5) although encephalopathy is not easily quantifyable in this species. Lysis of body cell mass results in an outpouring of branched-chain amino acids which can be metabolized peripherally, and of aromatic amino acids and methionine, which rely for metabolism on the liver. Many catabolic states indeed show increased plasma levels of these compounds, but especially so in liver disease.

In addition, extremely elevated plasma glutamine levels are observed in hepatic encephalopathy as well as in other catabolic states.

Glutamine is derived from proteolysis and is largely formed in muscle from non-essential amino acids. The gut metabolizes glutamine and produces glucose and ammonia from it. This equally occurs in the kidney. The liver metabolizes glutamine and produces glucose and urea from it. When liver function deteriorates, glutamine accumulates, and must be metabolized by gut or kidney who generate ammonia in the process.

Consequently, prevention of net protein breakdown and the achievement of anabolism may be of benefit in the treatment of hepatic encephalopathy. The administration of F080 restores anabolism, channelling $\alpha$ amino nitrogen back into protein synthesis, decreasing hyperaminoacidemia.

Conventional amino acid mixtures however sustain a dissociation in amino acid pattern because they add to a surplus of methionine and phenylalanine. Omitting these "bad" amino acids and adding branched-chain amino acids normalizes amino acid patterns, creating a "balanced" precursor pattern for protein synthesis allowing the "bad" amino acids to be taken up, relieving the failing liver from the necessity to catabolize these amino acids. This normalizes neutral amino acid patterns, pools and the pattern of uptake into the brain, presumably achieving improvement in neurological status.

\subsection{Clinical Practice}

In the pilot study that we reported (chapter 4) hepatic encephalopathy in 
chronic liver disease was precipitated by several seemingly unrelated factors, including sepsis, diuretics and catecholamine discharge (84). Thus, Schenker (90) has proposed the concept of "increased cerebral sensitivity" in patients with chronic liver disease to explain why varied stimuli result in hepatic encephalopathy. These stimuli however, caused in the patients with chronic liver disease and hepatic encephalopathy described in chapter 4 an identical plasma amino acid pattern, including raised plasma aromatic amino acids and decreased branched-chain amino acids. The catabolic state encountered in these patients (chapter 4), in dogs with hepatic encephalopathy (chapter 2) and the close correlation observed between nitrogen balance, plasma- and brain aromatic amino acids and octopamine (chapter 5) suggests that lysis of body cell mass may be the common denominator in coma-precipitating factors, that we are looking for. This is evident for sepsis, operations and shock secundary to upper gastro-intestinal bleeding. The coma-precipitating effect of a large variety of diuretics is common knowledge.

Attention has focused on electrolyte disturbances (127), and increased renalvein ammonia associated with diuretics. It has not been possible however to link diuretic-induced hepatic encephalopathy to one type of plasma electrolyte disturbance. Hypokalemia $(128,129)$ and metabolic alkalosis $(130)$ induced by diuretics have been associated with the occurrence of encephalopathy. Both electrolyte disturbances increase renal-vein ammonia levels. Alkalosis favours the formation of freely diffusible ammonia and therefore enhances the transfer of ammonia into the brain. Metabolic alkalosis and hypokalemia are not always present in diuretic-induced hepatic encephalopathy (127) however, so that the exact mechanism remains uncertain.

Therefore, alternative mechanisms may be proposed. Diuretics are known to cause hyperglycemia and to aggravate pre-existing diabetes $(131,132,133)$. Unger (134) has suggested, that diuretic-induced hypokalemia is associated with decreased insulin release, and decreased glucagon suppressibility. Total body-potassium depletion in cirrhotic patients, which may exist in the presence of normal plasma potassium levels, is associated with a diabetic glucose tolerance test and reduced output of both insulin and growth hormone (135). These changes are reversible with potassium repletion. The diabetic state associated with insufficient insulin secretion results in protein breakdown resulting in detrimental effects on neurological status. Thus, the diuretic-induced hepatic encephalopathy may, much like sepsis, shock, etc. be viewed as a complication or an accompaniment of the catabolic state. The therapeutic implications of this statement are that the promotion of anabolism may result in improvement of hepatic encephalopathy, a suggestion confirmed by observations in dogs and man in whom the initiation of parenteral nutrition with a glucose-amino acid mixture high in branched-chain amino acids and low in aromatic amino acids and glucose was associated with nitrogen retention, weight gain, and the restoration of the normal neurological state. 


\subsection{Validity hepatic encephalopathy hypothesis.}

\section{Ammonia hypothesis}

Evidence concerning the validity of the ammonia hypothesis through the decades at best has been circumstantial, including the demonstration of a correlation between plasma ammonia levels and hepatic encephalopathy. The demonstration that therapies designed to decrease ammonia production in the gut improved hepatic encephalopathy, was considered to be proof for a causal relationship. The administration of laxatives, and non-absorbable antibiotics however by no means exert effects that are exclusively limited to gutflora and to the production of ammonia, precluding the possibility to pinpoint ammonia as the cause of hepatic encephalopathy. In addition, many authors have departed from the assumption that ammonia was toxic in itself causing encephalopathy, without taking into consideration the mechanism which is responsible for normal consciousness. There is as much or more reason to assume that "toxic" substances can only interfere with normal consciousness, when they interfere with the normal physiological biochemical mechanism responsible for normal consciousness (hypoxia and lack of energy substrate set aside). Ammonia is both formed and metabolized in the organism and glutamine, the main precursor of ammonia is elevated in encephalopathy as much as ammonia is. Consequently, there is no reason to designate ammonia exclusively as the cause of hepatic encephalopathy. The main reason that this has been implicated as such is, that plasma ammonia levels could be measured long ago, and have been found the best correlating parameters of the few blood tests that could be done.

Rather would it seem preferable to us to include ammonia in a unifying concept concerning the genesis of hepatic encephalopathy and to determine the part that ammonia plays in the hypernitrogenous state and the dissociation in groups of amino acids, with regard to normal neurochemistry underlying consciousness. The most convincing evidence concerning the validity of the ammonia hypothesis has been that measures instituted to decrease ammonia production in the gut coincided with improvements in hepatic encephalopathy. The administration of laxatives for instance may diminish the absorption of nitrogen from the gut. This not only applies to the nitrogen ingested, but also to the nitrogen secreted in the gutlumen (enzymes, exfoliation of cells). Munro (136) has calculated that daily some $300 \mathrm{~g}$ of amino acids are resorbed from the gut when $100 \mathrm{~g}$ of protein is consumed orally. The residual $200 \mathrm{~g}$ must be derived from splanchnic protein in itself. Laxatives may relieve the liver from the necessity to metabolize this amount of lysed gut protein. Neomycin may equally interfere with resorption through mechanisms probably interfering with protein synthesis. These observations attenuate the proposed causality of ammonia in hepatic encephalopathy.

Our experiments do not exclude ammonia as an important factor in hepatic encephalopathy. The administration of F080 for instance coincided with striking decreases in ammonia levels. This has equally been demonstrated after infusion of glucose. The mechanism is not immediately apparent. Enhanced protein synthesis may channel ammonia into muscle protein, may 
enhance the ability of the liver to metabolize ammonia and may decrease ammonia production in the kidney. A very significant relationship however between a decrease in plasma ammonia levels and encephalopathy was not established, as the data presented in chapter 2 suggest that Freamine II equally caused a decrease in ammonia levels which did not coincide with an improvement in hepatic encephalopathy.

\section{Amino acid - neurotransmitter hypothesis}

The data presented in chapter $2,3,4,5$ are in agreement with the amino acid neurotransmitter hypothesis, but do not prove the validity of this hypothesis, because the infusion of F080 elicits a multitude of metabolic events which cannot be separated from each other. In the dog model, it has been proven however, that addition of branched-chain amino acids and withdrawal of aromatic amino acids is crucial in maintaining or achieving normal neurological state. There is evidence (chapter 5), that infusions of extra branched-chain amino acids and withdrawal of aromatic amino acids coincide with normalization of the concentration of substances in the brain that are considered to be physiological neurotransmitters, whereas it is an established fact that neutral amino acids have a common transport mechanism across the blood-brain barrier so that plasma levels in some way determine the neutral amino acid brain concentration including the aromatic amino acids which are precursors of some physiological neurotransmitters. It is not clear why neutral amino acid concentrations are so much more elevated inside the brain than in the plasma. Nor is it clear, what exactly determines brain tryptophan concentrations. It is still moot how increased aromatic amino acid brain concentrations exactly interfere with neurotransmitter metabolism, and it is totally speculative whether the reported changes in neurotransmitters in the brain are responsible for the changes in consciousness.

In conclusion, the data presented show that high concentrations of amino acids and low concentrations of aromatic amino acids in the amino acid glucose mixtures infused, are essential in achieving improvement in hepatic encephalopathy. This suggests at best that normalization of neutral amino acid pools is important. Normalization of neutral amino acid pools may be achieved by the specific amino acid composition of the mixture, by restoration of anabolism, and maybe by a beneficial hepatotrophic effect of the solution, and coincides with normalization of some neurotransmitters. 


\section{Summary}

In chapter 1, difficulties are described, encountered in studying "hepatic encephalopathy". An overview is given of current hypotheses and the problems involved in proving their validity. The "Amino acid-

Neurotransmitter hypothesis is described in more detail because it served as the basis for the experiments that are described in this thesis. An outline is given of these experiments.

In chapter 2, experiments are described which were carried out to determine if infusion of glucose amino acid mixtures specifically designed to normalize pathologic plasma amino acid patterns in dogs with hepatic encephalopathy, allowed adequate protein feeding without deterioration of encephalopathy. Eight dogs developed hepatic encephalopathy after receiving a porta-caval shunt. They were infused in a randomized cross-over fashion with a glucoseamino acid mixture $(4 \mathrm{~g}$ amino acids $/ \mathrm{kg} / 24 \mathrm{hrs}$ ) of a specific amino acid composition (F080), calculated to normalize the pathological plasma amino acid pattern encountered in hepatic encephalopathy, or a glucose-amino acid mixture with a reduced amino acid content $(2 \mathrm{~g}$ amino acids $/ \mathrm{kg} / 24 \mathrm{hrs}$ ) of a conventional composition (Freamine II).

- A marked improvement in neurological state was observed in all dogs receiving F080, whereas dogs which received Freamine II did not improve significantly, or even deteriorated neurologically.

- The ratio between the sum of the plasma branched-chain amino acids and the sum of the aromatic amino acids tyrosine and phenylalanine, which has been claimed to be a sensitive indicator for hepatic encephalopathy, improved after infusion of F080 and did not improve with Freamine II.

- This ratio did not distinguish however between dogs subjected to portacaval anastomosis with and without hepatic encephalopathy.

- Plasma ammonia levels tended to decrease after infusion of both types of solution.

- The addition of branched-chain amino acids and withdrawal of aromatic amino acids is crucial for the achievement of a beneficial effect on neurological status.

In chapter 3, experiments are described to shed light on the possible relationship between the pathological plasma amino acid pattern of liver disease and hepatic coma, and the plasma insulin- and glucagon levels. Plasma insulin- and glucagon levels and coinciding plasma amino acid patterns and glucose levels were determined in dogs before and after portacaval anastomosis and when hepatic encephalopathy had developed.

Arginine infusion tests were performed.

- A modest hyperinsulinemia was observed after porta-caval anastomosis. Plasma insulin levels tended to normalize when hepatic encephalopathy had developed.

- Modest hyperglucagonemia developed after porta-caval anastomosis.

- Hyperglucagonemia became marked in hepatic encephalopathy and 
coincided with a high catabolic rate.

- Hyperaminoacidemia was most pronounced in hepatic encephalopathy and a possible relationship with hyperglucagonemia and the catabolic state is discussed.

- An inverse temporary relationship between plasma branched-chain amino acid levels and plasma insulin levels was noted and a possible relationship is suggested.

To confirm the apparent good results reported in chapter 2, the use of F080 is studied in chapter 4 in an anecdotal group of eight patients with chronic cirrhosis and in 3 patients with fulminant hepatitis.

- Hyperaminoacidemia was most severe in fulminant hepatitis and involved all amino acids with the exception of the plasma branched-chain amino acids, which were within the normal range.

- Hepatic encephalopathy improved in all 8 patients with chronic cirrhosis and in only one patient with fulminant hepatitis.

- From this pilot study, it can be concluded that adequate amounts of amino acids can be fed to patients with hepatic encephalopathy, provided that a specific amino acid composition is employed.

- Various events precipitating hepatic encephalopathy coincide with the same plasma amino acid pattern.

- Dose-response curves were observed: when more F080 was infused, lower concentrations of plasma aromatic amino acids and ammonia were observed even though the solution contained some of these substances.

To study the role of anabolism, in chapter 5 the influence of exogenous enteral or parenteral intake was determined on plasma and brain concentrations of aromatic amino acids and octopamine, in rats subjected to sham-operation or to porta-caval shunt.

- In sham-operated animals, the composition of amino acids administered, appeared to have little effect on the plasma and brain aromatic amino acids and octopamine. After end-to-side porta-caval shunt, plasma and brain concentrations of aromatic amino acids were responsive to exogenous intake.

- In rats with end-to-side porta-caval shunts, graded increments of amino acids were given. When the animals achieved positive nitrogen balance, plasma and brain aromatic amino acid concentrations and-octopamine, decreased.

- The results suggest that in rats with end-to-side porta-caval shunts, exogenous intake and the level of catabolism influence plasma and brain aromatic amino acids.

Chapter 6 comprises experiments, devised to elucidate possible mechanisms involved in the genesis of the decrease in plasma branched-chain amino acid levels in rats subjected to porta-caval shunt.

The fate of labelled leucine was determined in in vitro incubations of pieces of tissue obtained from rats subjected to sham-operation or to porta-caval shunt. 
Incorporation of leucine into protein and fat, combustion to $\mathrm{CO}_{2}$, and free leucine pools were determined. No significant differences were observed for diaphragm and kidney between rats with porta-caval shunts or control rats. A significant increase in the incorporation of leucine derived carbon into fatty acid in adipose tissue was observed in rats with porta-caval shunts. It is suggested that adipose tissue may be involved in the regulation of plasma leucine levels.

In chapter 7 , a comprehensive interpretation is given of the data presented in chapters 2-6. It should be realized that conclusive evidence in this area of research is difficult to achieve. Therefore, it is attempted to separate facts from tentative conclusions and suggestions.

Metabolic abnormalities in hepatic encephalopathy.

- It is suggested from the data presented in chapter 2,3 and 4 and from the literature, that decreased plasma branched-chain amino acid levels may have positive prognostic significance.

- In chapter 3, an inverse relationship is demonstrated between plasma branched-chain amino acid levels and insulin levels, suggesting and confirming suggestions from the literature, that hyperinsulinism encountered in dogs with porta-caval shunts may cause decreased branched-chain amino acid levels.

- Hyperglucagonism is most extreme in encephalopathy, suggesting that porta-caval shunt per se only moderately increases glucagon levels, but that liver failure elicits hypersecretion of glucagon.

- It is speculated that the hypernitrogenous state in hepatic encephalopathy may cause hypersecretion of glucagon.

- The $\frac{\text { valine }+ \text { isoleucine + leucine }}{\text { tyrosine }+ \text { phenylalanine }}$ ratio is uniformly decreased after porta-caval shunt in dogs but does not distinguish between dogs with porta-caval shunt with and without hepatic encephalopathy.

- It is speculated that the direct incorporation of leucine carbon into fatty acid in adipose tissue may contribute to decreased leucine levels in liver disease.

Amino acid - glucose infusions

- F080 can be administered in dogs in hepatic encephalopathy (chapter 2) in sufficient amounts to cover protein requirements, at the same time achieving improvement in neurological status. This was equally observed in a small anecdotal study in man (chapter 4) with hepatic encephalopathy due to cirrhosis. No toxic side-effects were noted at any time.

- The addition of branched-chain amino acids and withdrawal of the largest part of aromatic amino acids, compared to conventional solutions, seems crucial. The mechanism may involve three different aspects:

1. The glucose-amino acid mixture may have a hepatotrophic effect.

2. The solution achieves a "normalization" of the plasma neutral amino acid pattern influencing the pattern of uptake into the brain.

3. Anabolism is achieved, normalizing amino acid patterns, amino acid pools and relieving hyperaminoacidemia. 
- An important common denominator in several factors precipitating hepatic encephalopathy may be catabolism.

- The data presented in this thesis are in agreement with the amino acidneurotransmitter hypothesis. They do not exclude other theories however. The merit of the amino acid-neurotransmitter hypothesis in our opinion, is that it focuses on disturbances in physiological neurotransmitter metabolism and interference with normal neurological state. We do not pinpoint aromatic amino acids as the only culprits in the pathogenesis of hepatic encephalopathy. They are part of the hypernitrogenaus state including many other nitrogen containing molecules like glutamine, $\mathrm{NH}_{3}$ and methionine, all of which may be related to hepatic encephalopathy. 


\section{Samenvatting}

In hoofdstuk 1 worden de moeilijkheden beschreven die rijzen bij onderzoek naar het levercoma.

$\mathrm{Na}$ een overzicht te hebben gegeven van de bestaande hypotheses over de etiologie en van de problemen die zich voordoen bij pogingen om deze hypotheses te rechtvaardigen, volgt een uitvoerige beschrijving van de "aminozuur-neurotransmitter hypothese", die als uitgangspunt diende voor het experimenteel werk, dat in dit proefschrift beschreven wordt.

In hoofdstuk 2 worden experimenten beschreven, uitgevoerd om het effect te bestuderen van het infunderen van specifieke aminozuur-glucose mengsels bij honden in levercoma. Dit mengsel werd samengesteld met als doel het pathologische aminozuurspectrum, dat optreedt in levercoma, te corrigeren. Het materiaal bestond uit acht comateuze honden na een porta-cavale shunt operatie. Zij kregen een infuus bestaande uit, hetzij het specifiek aminozuur glucose mengsel (FO80; $4 \mathrm{~g}$ aminozuren $/ \mathrm{kg} / 24$ uur), hetzij een aminozuur glucose mengsel van conventionele samenstelling (Freamine Il; $2 \mathrm{~g}$ aminozuren $/ \mathrm{kg} / 24$ uur). Na verloop van 12 dagen werd de reciproke voedingsoplossing geïnfundeerd bij de nog in leven zijnde honden.

- Bij alle honden die F080 kregen, trad een duidelijke verbetering op in het sensorium, terwijl dit onveranderd bleef of verslechterde na infusie van Freamine II.

- De ratio tussen de som van de vertakte keten aminozuren en de som van de aromatische aminozuren: tyrosine en phenylalanine - die een gevoelige parameter zou zijn voor levercoma - verbeterde na infusie van F080, doch niet na infusie van Freamine II.

- Deze ratio liet echter geen onderscheid zien tussen honden met een portocavale shunt, mèt en zonder encephalopathie.

- Plasma ammoniakspiegels vertoonden een neiging tot dalen na infusie van beide oplossingen.

- De toevoeging van vertakte keten aminozuren en het weglaten van aromatische aminozuren bleek essentieel voor het bereiken van een gunstig effect op het levercoma.

De experimenten beschreven in hoofdstuk 3 trachten een inzicht te geven omtrent het mogelijke verband tussen het afwijkende plasma aminozuurpatroon, dat optreedt bij leverziekten en levercoma, en plasma insuline- en glucagonspiegels.

Plasma insuline- en glucagonspiegels, het plasma aminozuurspectrum en de plasma glucosespiegels werden bepaald bij honden vóór en na het aanleggen van een porto-cavale shunt, en na het optreden van encephalopathie. - Plasma insulinespiegels waren licht verhoogd na het aanbrengen van een porto-cavale shunt, maar bereikten normale waarden na het optreden van encephalopathie.

- Plasma glucagonspiegels waren eveneens licht verhoogd na het aanleggen van een porto-cavale shunt, maar stegen significant toen de proefdieren 
tekenen van encephalopathie vertoonden. Tevens bleken deze honden ook katabool te zijn.

- Het verband tussen de hoge plasma glucagonspiegels en het katabolisme wordt besproken.

- De verhoging van aminozuurspiegels in het plasma was het meest uitgesproken bij encephalopathie.

- Er lijkt een omgekeerde correlatie te bestaan tussen verlaagde plasma vertakte keten aminozuurspiegels en plasma insulinespiegels. Mede op basis van de literatuurgegevens wordt het mogelijk geacht, dat er een causaal verband bestaat tussen deze gegevens.

De goede resultaten met F080, vermeld in hoofdstuk 2, vormden de basis voor het gebruik van F080 in een kleine, geselecteerde groep patienten. Deze groep bestond uit 8 patienten met levercirrhose en 3 patienten met hepatitis. De ervaringen opgedaan bij deze patienten, worden beschreven in hoofdstuk 4 . - Plasma aminozuurspiegels waren het sterkst verhoogd bij patienten met een foudroyant verlopende hepatitis. Deze verhoging betrof alle aminozuren, met uitzondering van de vertakte keten aminozuren die normale concentraties hadden.

- Een verbetering van de encephalopathie werd bereikt bij alle 8 patienten met cirrhosis en slechts bij 1 patient met acute hepatitis.

- Er trad steeds hetzelfde plasma aminozuurpatroon op, ongeacht de aard van de metabole verstoring die aanleiding had gegeven tot het ontstaan van encephalopathie.

- Er bestond een relatie tussen het bereikte effect en de hoeveelheid toegediende F080. Wanneer meer F080 werd geïnfundeerd, daalden de aromatische aminozuur- en ammoniakconcentraties ondanks het feit dat deze oplossingen aromatische aminozuren bevatten.

- De resultaten van deze studie tonen aan dat patienten in levercoma gevoed kunnen worden met aminozuur bevattende oplossingen, mits deze een speciale aminozuursamenstelling hebben.

Teneinde de rol van anabolisme te bestuderen, wordt in hoofdstuk 5 de invloed nagegaan van enterale en parenterale voeding op aromatische aminozuren- en octopamine- concentraties in het plasma en in de hersenen bij ratten mèt en zonder porto-cavale shunt.

- De samenstelling van de toegediende aminozuren had bij controleratten weinig invloed op de aromatische aminozuren- en octopamineconcentraties in het plasma en de hersenen. Na een porto-cavale shunt operatie waren de concentraties van de aromatische aminozuren in het plasma en in de hersenen afhankelijk van de voedselopname.

- Aan ratten met porto-cavale shunts, werden geleidelijk toenemende hoeveelheden aminozuren parenteraal toegediend. Naarmate de stikstofbalans duidelijker positief werd, daalden de concentraties van de aromatische aminozuren en octopamine in het plasma en in de hersenen.

- De resultaten suggereren dat de hoeveelheid toegediende F080 èn de stikstofbalans, de concentratie van de aromatische aminozuren in het plasma en in de hersenen kunnen beïnvloeden. 
Hoofdstuk 6 beschrijft de experimentele benadering van het mechanisme, dat ten grondslag ligt aan de daling van de vertakte keten aminozuren concentratie in het plasma, die optreedt na het aanleggen van een portocavale shunt in de rat. Hiertoe werd het metabolisme van leucine bestudeerd middels in vitro incubaties van weefselstukjes afkomstig van controleratten en van ratten die een porto-cavale shunt operatie ondergingen.

De inbouw van leucine en spiereiwit, niereiwit en vet, de verbranding van leucine tot $\mathrm{CO}_{2}$ en van leucine in de vrije vet-"pool" werden bepaald. In weefselfragmenten afkomstig van diafragma en nier konden geen significante verschillen worden aangetoond tussen ratten mèt en zonder portocavale shunt. Er trad een significante toename van de inbouw van van leucine afkomstige koolstofatomen in vetzuren in het vetweefsel op in ratten met een porto-cavale shunt. Dit suggereert dat vetweefsel een rol speelt bij de regulatie van plasma leucinespiegels.

In hoofdstuk 7 worden de resultaten, vermeld in hoofdstuk $2 \mathrm{t} / \mathrm{m} 6$, geïnterpreteerd en waar mogelijk conclusies getrokken.

Metabole afwijkingen die optreden bij levercoma.

- Op grond van gegevens, vermeld in de hoofdstukken 2, 3 en 4 en in de literatuur, wordt de suggestie gewekt dat verlaagde plasma vertakte keten aminozuurspiegels een gunstige prognostische betekenis hebben.

- In hoofdstuk 3 wordt een omgekeerde relatie aangetoond tussen plasma vertakte keten aminozuurspiegels en insulinespiegels. Dit bevestigt aanwijzingen uit de literatuur, dat verhoogde insulinespiegels bij honden met porto-cavale shunts verantwoordelijk zijn voor lage vertakte keten aminozuurspiegels.

- Verhoogde plasma glucagonspiegels zijn het meest uitgesproken bij encephalopathie. Dit wijst er op, dat vooral de leverinsufficiënte en niet de porto-cavale shunt verantwoordelijk is voor een hypersecretie van glucagon.

- Het is mogelijk dat een verhoging van de plasma aminozuurconcentraties tijdens levercoma een hypersecretie van glucagon induceert.

- De $\frac{\text { valine }+ \text { isoleucine }+ \text { leucine }}{\text { tyrosine }+ \text { phenylalanine }}$ ratio is verlaagd na het aanleggen van een porto-cavale shunt bij honden. Deze ratio daalt echter niet verder als zich het levercoma ontwikkelt.

- Het is mogelijk dat de directe inbouw van van leucine afkomstige koolstofatomen in vetzuren in vet bijdraagt tot een daling van plasma leucinespiegels bij patienten en proefdieren met leverinsufficiëntie.

\section{Aminozuur-glucose infusies}

- F080 kon bij honden met levercoma (hoofdstuk 2) in voldoende hoeveelheden worden toegediend om de eiwitbehoefte te dekken. Tegelijkertijd werd een verbetering van het sensorium bereikt. Dit kon ook bereikt worden in een kleine, geselecteerde groep patienten met levercoma op basis van levercirrhose (hoofdstuk 4). Er werden geen toxische neveneffecten waargenomen. 
- Het toevoegen van vertakte keten aminozuren en het achterwege laten van het grootste deel van de aromatische aminozuren, vergeleken met conventionele aminozuuroplossingen lijkt essentieel voor het bereiken van het gesignaleerde effect.

Het mechanisme dat aan dit effect ten grondslag ligt, heeft drie mogelijke aspecten:

1. Het glucose - aminozuur mengsel kan een hepatotroop effect hebben.

2. De oplossing "normaliseert" het plasmapatroon van de neutrale aminozuren waardoor normalisatie optreedt van het neutrale aminozuurpatroon, opgenomen in de hersenen.

3. Door het bereiken van anabolisme wordt het plasma aminozuurpatroon genormaliseerd, en treedt er een daling op van de hoge plasma aminozuurspiegels.

- Een belangrijk gemeenschappelijk kenmerk van de verschillende factoren die levercoma doen ontstaan, is katabolisme.

- De gegevens vermeld in dit proefschrift zijn in overeenstemming met de "aminozuur - neurotransmitter hypothese". Zij sluiten andere hypotheses echter niet uit. De verdienste van de "aminozuur - neurotransmitter hypothese" is, naar onze mening, dat deze zich bezighoudt met verstoringen in het physiologische neurotransmitter metabolisme en met stoornissen in het normale bewustzijn. Het ligt geenszins in onze bedoeling de aromatische aminozuren als de enige verantwoordelijke factoren aan te wijzen bij het ontstaan van encephalopathie. Zij zijn onderdeel van een toenemen van vele stikstof bevattende moleculen, zoals o.a. glutamine, $\mathrm{NH}_{3}$ en methionine, die eveneens van betekenis kunnen zijn bij het ontstaan van een hepatische encephalopathie. 


\section{References}

\section{McDermott W.V., Adams R.D.}

Episodic stupor associated with Eck fistulas in the human with particular reference to the metabolism of ammonia.

J.Clin.Invest.44:1,1954.

2 McDermott W.V.

The role of ammonia intoxication in hepatic coma.

Bull. N.Y. Acad.Med. 34:352,1958.

3 Nencki M., Pavlow J.P., Zaleski J.

Über den Ammoniakgehalt des Blutes und der Organe und die Harnstoffbildung bei den Säugetieren.

Arch.Exp.Path.Pharmacol.37:26,1896.

4 Monguio J., Krause F.

Über die Bedeutung der Leberfunktion.

Klin. Wochenschr.13:1142,1934.

5 Bessman S.P., Bessman A.W.

The cerebral and peripheral uptake of ammonia in liver disease with a hypothesis for the mechanism of hepatic coma.

J.Clin.Invest.34:622,1955.

6 Fazekas J.F., Ticktin H.E., Ehrmantraut W.R., et al.

Cerebral metabolism in hepatic insufficiency.

Am.J.Med. 21:843,1956.

7 Posner J.B., Plum F.

The toxic effects of carbon dioxide and acetozolamide in hepatic insufficiency.

J.Clin.Invest. 39:1246,1960.

\section{Erbsloh F.}

Comments on liver-brain correlations in systemic hypoxaemia.

In: Selective Vulnerability of the Brain in Hypoxaemia, edited by J.P. Schade and W.H. McMenamy. Philadelphia, Davis F.A., 1963, p.305.

9 Polli E., Bianchi-Porro G., Maiolo A.T.

Cerebral metabolism after porta-caval shunt.

Lancet $1: 153,1969$.

10 Schenker S., Mendelson J.H.

Cerebral adenosine triphosphate in rats with ammonia-induced coma.

Am.J.Physiol.206:1173,1964.

11 Biebuyck J., Funovics J., Dedrick D.F., et al.

Neurochemistry of hepatic coma. Alterations in putative neurotransmitter amino acids.

In : Artificial Liver Support, edited by R. Williams and I.M.Murray-Lyon.

London, Pitman Medical, 1975, p.51

12 Hawkins J., Miller A.L., Nielsen R.C., et al.

The acute action of ammonia on rat brain metabolism in vivo.

Biochem.J. 134:1001,1973.

13 Veech R.L., Harris R.L., Veloso D., et al.

Freeze blowing: A new technique for the study of brain in vivo. 
Biochem.Pharmacol.20:183,1973.

14 Zieve F.J., Zieve L., Doizaki W.M., et al.

Synergism between ammonia and fatty acids in the production of coma: Implications for hepatic coma.

J.Pharmacol.Exp.Ther. 191:10,1974.

15 Takahashi Y.

Serum lipids in liver disease. Liver disease and the relationship of serum lipids and hepatic coma.

Jpn.J. Gastroenterology 60:571,1963.

16 Chen S., Mahadevan V., Zieve L.

Volatile fatty acids in the breath of patients with cirrhosis of the liver.

J.Lab.Clin.Med. 75:622,1970.

17 Hilary Morgan, H., Bolton C.H., Morris J.S., et al.

Medium chain triglycerides and hepatic encephalopathy.

Gut 15:180,1974.

18 Tanaka K., Isselbacher K.F., Shih V.

Isovaleric and alpha-methylbutyric acidemias induced by hypoglycin A:

Mechanism of Jamaican vomiting sickness.

Science 175:69,1972.

19 Budd M., Tanaka K., Holmes L.B., et al.

Isovaleric acidemia : clinical features of a new genetic defect of leucine metabolism.

N.Engl.J.Med. 227:321,1967.

20 Walker C.O., McCandless D.W., McGarry J.D., et al.

Cerebral energy metabolism in short chain fatty acid - induced coma.

J. Lab. Clin. Med. 76:569, 1970.

21 Dodsworth J.M., James J.H., Cummings M.G. et al.

Depletion of brain norepinephrine in acute hepatic coma.

Surgery $75: 811,1974$.

22 Fischer J.E.

Hepatic coma in cirrhosis, portal hypertension and following porta-caval shunt.

Arch.surg. 108:325,1974.

23 Fischer J.E., and Baldessarini R.J.

False neurotransmitters and hepatic coma.

Lancet 2:75,1971.

24 Fischer J.E., and James J.H.

Treatment of hepatic coma and hepatorenal syndrome: Mechanism of action of L-dopa and aramine.

Am.J.Surg. 123:222,1972.

25 Molinotf P.B., Axelrod J.

Octopamine: Normal occurrence in sympathetic nerves of rats.

Science 164:428,1969.

\section{Fischer J.E.}

False neurotransmitters and hepatic coma.

Res.Publ.Assoc.Res.Nerv.Ment.Dis.53:53, 1974.

27 Baldessarini R.J., Karobath $M$.

Biochemical physiology of central synapses. 
Ann.Rev.Physiol.35:273,1973.

28 Aguirre A., Yoshimura N., Westman T., et al.

Plasma amino acids in dogs with two experimental forms of liver damage.

J.Surg.Res. 16:339,1974.

29 Fischer J.E., Horst W.D., Kopin I.J.

$\beta$-hydroxylated sympathomimetic amines as false neurotransmitters.

Br.J.Pharmacol. 24:477,1965.

30 Fischer J.E., Weise V.K., Kopin I.J.

False adrenergic transmitter release from the isolated cat heart.

Am.J.Med.Sci. 225:158,1968.

31 Lam K.C., Tall A.R., Goldstein G.B., et al.

The role of a false neurotransmitter, octopamine, in the pathogenesis of

hepatic and renal encephalopathy.

Scand.J.Gastroenterology 8:456,1973.

32 Manghani K.K., Lunzer M.R., Billing B.H. et al.

Urinary and serum octopamine in patients with portal systemic

encephalopathy.

Lancet 2:943,1975.

33 Livingstone A., Hinchey E.J., Goresky C.A.

Changes in the blood-brain barrier in acute hepatic coma.

Surg.For.25:351,1974.

34 Mattson W.J.Jr., lob V., Sloan M., et al.

Alterations of individual free amino acids in brain during acute hepatic coma.

Surg.Gynecol.Obstet.130:263,1970.

35 lob V., Mattson W.J.Jr., Sloan M., et al.

Alterations in plasma - free amino acids in dogs and hepatic insufficiency.

Surg.Gynecol.Obstet 130:794,1970.

36 Richmond J., Girdwood R.H.

Observations on amino acid absorption.

Clin.Sci.22:301,1962.

37 Iber F.L., Rosen H., Levenson S.M., et al.

The plasma amino acids in patients with liver failure.

J.Lab.Clin.Med. 50:417,1957.

38 lob V., Coon W.W., Sloan M.

Altered clearance of free amino acids from plasma of patients with cirrhosis of the liver.

J.Surg.Res. 6:233,1966.

39 Svec M.H., Freeman S.

Effect of impaired hepatic circulation on plasma free amino acids of dogs.

Am.J.Physiol. 159:357,1949.

40 McMenamy R.J., Vang J.H., Drapanas T.

Amino acids and $\alpha$-keto acid concentrations in plasma and blood of the liverless dog.

Am.J.Physiol. 209:1046,1965.

41 Fernstrom J.D., and Wurtman R.J.

Brain serotonin content: Physiological regulation by plasma neutral amino acids.

Science 178:414,1972. 
42 Oldendorf W.H.

Brain uptake of radiolabelled amino acids, amines and hexoses after arterial injection.

Am.J.Physiol. 221:1629,1971.

\section{Wurtman R.J.}

Aromatic amino acids and the brain.

In: Ciba symposium vol.22 (new series). London 1974. Elseviers Publishing

Company.

44 Orlowski M.G., Sessa J.P., Green J.P.

$\lambda$-glutamyl transpeptidase in brain capillaries: Possible site of a blood-brain barrier for amino acids.

Science 184:66,1974.

45 David J.C., Dairman J.C., Udenfriend S.

Decarboxylation to tyramine: A major route of tyrosine metabolism in mammals.

Proc.Natl.Acad.Sci U.S.A., 71:1771,1974.

46 Fischer J.E., and Baldessarini R.J.

Pathogenesis in therapy of hepatic coma.

In: Progress in liver disease, edited by Schaffner F., and Popper H. vol.5, New York, 1976, Grune \& Stratton Inc.

47 James J.H., Hodgman J.M., Funovics J.M., et al.

Brain tryptophan, plasma free tryptophan and distribution of plasma neutral amino acids.

Metabolism 25:472,1976.

48 Fischer J.E., James J.H., Keane J.M., et al.

An alternative mechanism for the beneficial effects of intestinal sterilization in hepatic encephalopathy: effects of amino acid infusions.

Am.J.Surg. 127:40,1974.

49 Perez Cruet J., Chase T.N., Murphy D.L.

Dietary regulation of brain tryptophan metabolism by plasma ratio of free tryptophan and neutral amino acids in human.

Nature 248:693,1973.

50 Curzon G., Kantamaneri B.D., Winch J., et al.

Plasma and brain tryptophan changes in experimental acute hepatic failure. J.Neurochem. 21:137,1973.

51 Cummings M.G., James J.H., Soeters P.B., et al.

Regional brain study of indoleamine metabolism in the rat in acute hepatic failure.

J.Neurochem. 27:741, 1976.

52 Cummings M.G., Soeters P.B., James J.H., et al.

Regional brain indoleamine metabolism following chronic porta-caval

anastomosis in the rat.

J.Neurochem. 27:501,1976.

53 Fischer J.E., Funovics J.M., Aguirre A., et al.

The role of plasma amino acids in hepatic encephalopathy.

Surgery 78:276,1975.

54 Ono J., Hutson D.G., Duane G., et al.

Tryptophan and hepatic coma. 
Gastroenterology 74:196,1978.

55 Dencla W.D., and Dewey H.K.

The determination of tryptophan in plasma, liver and urine.

J.Lab.Clin.Med. 69:160,1967.

56 James J.H., Escourrou J., Fischer J.E.

Blood-brain neutral amino acid transport activity is increased after portacaval anastomosis.

Science 200:1395,1978

57 Record, C.O., Buxton B., Chase R.A., et al.

Plasma and brain amino acids in fulminant hepatic failure and their

relationship to hepatic encephalopathy.

Europ.J.Clin.Invest. 6:387,1976.

\section{Adibi S.A.}

Interrelationships between level of amino acids in plasma and tissues during starvation.

Am.J.Physiol. 221:829,1971.

59 Ruderman N.B., Berger M.

The formation of glutamine and alanine in skeletal muscle.

J.Biol.Chem. 249:5500,1974.

\section{Miller L.L.}

The role of the liver and the non-hepatic tissues in the regulation of free amino acid levels in the blood.

In: Amino Acid Pools, edited by Holden J.T. New York, Elsevier, 1967,p.708.

61 Odessey R., Khairallah E.A., Goldberg A.L.

Origin and possible significance of alanine production of skeletal muscle.

J.Biol.Chem. 249:7623,1974.

62 Felig P., Pozefsky T., Marliss E., et al.

Alanine: Key Role in Gluconeogenesis.

Science 167:1003,1970.

63 Smith A.R., Rossi-Fanelli F., Ziparo V., et al.

Alterations in plasma and CSF amino acids, amines and metabolites in hepatic coma.

Ann.Surg. 187:343,1978.

64 Starzl Th.E., Putnam Ch.W.

Portal diversion: treatment for glycogen storage disease and hyperlipemia.

J.A.M.A. 233:955, 1975.

65 Starzl Th.E., Putnam Ch.W., Porter Ken A., et al.

Portal diversion for the treatment of glycogen storage diseases in humans. Ann.Surg. 178:525,1973.

66 Bilheimer David W., Goldstein J.L., Grundy Scott M., et al.

Reduction in cholesterol and low density lipoprotein synthesis after portacaval shunt surgery in a patient with homozygous familial hyper-

cholesterolemia.

J.Clin.Invest. 56:1420,1975.

67 Starzl Th.E., Putnam Ch.W., Chase P.H., et al.

Porta-caval shunt in hyperlipoproteinaemia.

Lancet II:940,1973.

68 Starzl Th.E., Chase H.P., Putnam Ch.W., et al. 
Follow-up of patient with porta-caval shunt for the treatment of hyperlipidemia.

Lancet II:714,1974.

69 Winter I.C., Van Dolch J.E., and Crandall L.A. Jr.

The effect of liver damage by carbon tetrachloride on fatty acid utilization of rats receiving a fat-free diet.

Am.J.Physiol. 133:566,194.

70 Guzman Ignacio J., Coyle John J., Schneider Ph.D., et al.

The effect of selective visceral caval shunt on plasma lipids and cholesterol dynamics.

Surgery 82:42,1977.

71 Coyle John J., Schwartz M.Z., Marubbio Th., et al.

The effect of porta-caval shunt on plasma lipids and tissue cholesterol synthesis in the dog.

Surgery 80:54,1976.

72 James J.H., Soeters P.B., Escourrou J., et al.

Decreased cholesterol and fatty acid synthesis following porta-caval shunt.

Surg. Forum 88:397,1977.

73 Faloona G.R., and Unger R.H.

Glucagon.

In: Methods of Hormone Radioimmunoassay, edited by Jaffe B.M. and

Behrman H.R. Academic Press, New York 1974, p.317.

74 Fischer J.E., Yoshimura N., Aguirre A., et al.

Plasma amino acids in patients with hepatic encephalopathy: effects of amino acid infusions.

Am.J.Surg. 127:40,1974.

75 Sherwin R., Joshi P., Hendler R., et al.

Hyperglucagonemia in Laennec's cirrhosis.

N.Engl.J.Med. 290:239,1974.

76 Munro H.N., Fernstrom D., and Wurtman R.J.

Insulin, plasma amino acid imbalance and hepatic coma.

Lancet 1: 722,1975.

77 Rocha D.M., Santensanio F., Faloona J.R., et al.

Abnormal pancreatic $\alpha$-cell function in bacterial infections.

N.Engl.J.Med. 288:700,1973.

78 Wilmore D.W., Moylan J.A., Pruitt B.A., et al.

Hyperglucagonemia after burns.

Lancet 1:73,1974.

79 Gazzard B., Portmann R., Weston M.J. et al.

Charcoal hemoperfusion in the treatment of fulminant hepatic failure.

Lancet 1:1301,1974.

80 Opolon P., Rapin J.R., Huguet C., et al.

Hepatic failure. Coma treated by polyacrylonitrile membrane hemodialysis.

Presented at the meeting on artificial organ support, San Francisco, April 1st, 1976.

81 Valverde I., Villanueva M.L., Lazono I.

Presence of glucagon immunoreactivity in the globin fraction of human

plasma (big plasma glucagon). 
J.Clin.Endocrinol.Metab. 39:1090,1974.

82 Weir C.G., Knowlton S.D., and Martin D.B.

High molecular weight glucagon-like immunoreactivity in plasma.

J.Clin.Endocrinol.Metab. 40:296,1975.

83 Albano J.D., Elkins R.P., Maritz G.

A sensitive precise radio-immunoassay of serum insulin relying on charcoal separation of bound and free hormone moieties.

Acta Endocrinol. 70:487,1972.

84 Fischer J.E., Rosen H.M., Ebeid A.M., et al.

The effect of normalization of plasma amino acids on hepatic

encephalopathy in man.

Surgery 80:77,1976.

85 Ebeid A.M., Escourrou J., Soeters P.B., et al.

Hepatic inactivation of vasoactive intestinal peptide in man and dog.

Ann.Surg. 188:28,1978.

86 Lunzer H.R., Newman S.P., Bernard G., et al.

Impaired cardiovascular responsiveness in liver disease.

Lancet II:382,1975.

87 Mashford M.L., Mahon W.A., Chalmers T.C.

Studies of the cardiovascular system in the hypotension of liver failure.

New.Engl.J.Med. 267:1071,1962.

88 Rocha D.M., Faloona G.R., and Unger R.H.

Glucagon-stimulating activity of 20 amino acids in dogs.

J.Clin.Invest. 51:2346,1972.

89 Unger R. $H_{\text {. }}$

Glucagon and the insulin: glucagon ratio in diabetes and other catabolic

illnesses.

Diabetes 20:834,1971.

90 Schenker S.

Hepatic coma: current concepts of pathogenesis.

Viewpoints Dig.Dis.2:4,1970.

91 Bollman J., Flock E.V., Grindlay J.H., et al.

Coma with increased amino acids of brain in dogs with Eck's fistula.

Arch.Surg. 75:405, 1957.

92 Rosen H.M., Yoshimura N., Hodgman J.M., et al.

Plasma amino acid patterns in hepatic encephalopathy of differing aetiology.

Gastroenterology 72:483,1977.

93 Funovics J.M., Cummings M.G., Shuman L.A., et al.

An improved nonsuture method for porta-caval anastomosis in the rat.

Surgery 77:661,1975.

94 McCaman M.L., Rubin E.

Fluorometric method for the determination of phenylalanine in serum.

J.Lab.Clin. Med. 59:887,1962.

95 Wong P.W.K., O'Flynn H.E., Inouye T.

Micromethods for measuring phenylalanine and tyrosine.

Clin.Chem. 10:1098,1964.

96 Soeters P.B., Weir G., Ebeid A.M., et al.

Insulin, glucagon, portal systemic shunting and hepatic failure in the dog. 
J.Surg.Res. 23:183,1977.

97 Oldendorff W.H., Szabo J.

Amino acid assignment tone of three blood brain-barrier amino acid carriers. Am.J.Physiol. 23:94,1976.

98 Baldessarini R.J., Fischer J.E.

Serotonin metabolism in rat brain after surgical diversion of the portal venous circulation.

Nature (New Biology) 254:25,1973.

99 James J.H., Hodgman J.M., Funovics J.M., et al.

Alteration in brain octopamine and brain tyrosine following porta-caval anastomosis in rats.

J.Neurochem. 27:223,1976.

100 Escourrou J.C., James J.H., Hodgman J.M., et al.

Effect of branched-chain amino acids on plasma and brain amino acids and brain neurotransmitters.

Gastroenterology 71:904,1976 (abstract).

101 Madras B.K., Cohen E.L., Messing R., et al.

Relevance of free tryptophan in serum to tissue tryptophan concentrations. Metabolism 23:1107,1974.

102 Odessey R., Goldberg A.L.

Oxidation of leucine by rat skeletal muscle.

Am.J.Physiol. 223:1376,1972.

103 Goodman H.M.

Stimulatory action of insulin on leucine uptake and metabolism in adipose tissue.

Am.J.Physiol. 206:129,1964.

104 Marco J., Diego J., Villanueva Maria L., et al.

Elevated plasma glucagon levels in cirrhosis of the liver.

New Engl.J.Med. 289:1107,1973.

105 Lichley H.A., Chisholm D.J., Rabinovitch A., et al.

Effect of porta-caval anastomosis on glucose tolerance in the dog: evidence of an interaction between the gut and the liver in oral glucose disposal.

Metabolism 24:1157,1975.

106 Assal J.P., Levrat R., Stanffacher W., et al.

Metabolic consequences of porta-caval shunting in the rat: effects on glucose tolerance and serum immunoreactive insulin response.

Metabolism 20:850,1971.

107 Pozefsky T., Felig P., Tobin J.O., et al.

Amino acid balance across tissues of the forearm in postabsorptive man.

Effects of insulin at two dose levels.

J.Clin.Invest. 48:2273,1969.

108 Felig P., Marliss E., Ohman J.L., et al.

Plasma amino acid levels in diabetic ketoacidosis.

Diabetes 19:727,1970.

109 Adibi S.A., Drash A.L.

Hormone and amino acid levels in altered nutritional states.

J.Lab.Clin.Med. 76:722, 1970.

110 Falin $D$ Marlice F Cahill.I $\mathrm{T}$ ir 
Plasma amino acid levels and insulin secretion in obesity.

New Engl.J.Med. 281:811,1969.

111 Garber A.J., Karl I.E., Kipnis D.M.

Alanine and glutamine synthesis and release from skeletal muscle.

J.Biol.Chem. 251:836,1976.

112 Feller D.W.

Conversion of amino acids to fatty acids.

From: Handbook of Physiology. Section V. Adipose Tissue, chapter 37, p.363.

113 Shurberg J.L., Ros E., Resnick R.H., et al.

Serum lipids, insulin and glucagon after porta-caval shunt in cirrhosis.

Gastroenterology 71:937,1976.

114 McIntyre, N.

Signals for insulin secretion.

From: Hepatotrophic factors, Ciba Foundation Symposium 55, edited by

R. Porter and J. Whelan, Amsterdam, Elseviers Publishing Company 1978, p. 153.

115 Johnston D.G., Alberti K.G.M.M., Faber O.K., et al.

Hyperinsulinism of hepatic cirrhosis: diminished degradation or

hypersecretion?

Lancet 1:10,1977.

116 Bloom S.R.

Signals for glucagon secretion.

From: Hepatotrophic factors, Ciba Foundation Symposium 55, edited by

R. Porter and J. Whelan, Amsterdam, Elseviers Publishing Company 1978, p.161.

117 Starzl T.E., Porter K.A., Watanabe K., et al.

Effects of insulin, glucagon and insulin/glucagon infusions on liver morphology and cell division after complete porta-caval shunt in dogs.

Lancet 1:821,1976.

118 Floyd J.C., Fajans S.S., Conn J.W., et al.

Stimulation of insulin secretion by amino acids.

J.Clin.Invest. 45:1497,1966.

119 Milner R.D.G.

Stimulation of insulin secretion in vitro by essential amino acids.

Lancet 1:1075,1969.

120 Porter R., Whelan J.

Hepatotrophic factors, Ciba Foundation Symposium 55, 1978.

Amsterdam Elseviers Publishing Company.

121 Starzl T.E., Jones A.F., Terblanche J.

Growth-stimulating factor in regenerating canine liver.

Lancet I:127,1979.

122 Bucher N.L.R., and Swaffield M.N.

Synergistic action of glucagon and insulin in regulation of hepatic regeneration.

Personal communication.

123 Starzl T.E., Porter K.A., Kashiwagi N., et al.

The effect of diabetes mellitus on portal blood hepatotrophic factors in dogs.

Surg. Gynecol. Obstet 140:549,1975. 
124 Starzl T.E., Lee I.Y., Porter K.A., et al.

The influence of portal blood upon lipid metabolism in normal and diabetic dogs and baboons.

Surg.Gynecol.Obstet 140:381,1975.

\section{Editorial.}

Hepatotrophic factors.

Lancet II: $244,1978$.

126 Buse M.G., Reid S.S.

Leucine: A possible regulator of protein turn-over in muscle.

J.Clin.Invest. 56:1250,1975.

127 Sherlock S., Walker J.G., Senewiratne, et al.

The complications of diuretic therapy in patients with cirrhosis.

Am.N.Y.Acad.Sci. 139:497,1966.

128 Read A.E., Laidlaw J., Haslam R.M. et al.

Neuropsychiatric complications following chlorothiazide therapy in patients with hepatic cirrhosis: Possible relation to hypokalemia.

Clin.Sci. 18:409, 1959.

129 Baertl J.M., Sancetta S.M., Gabuzda G.J.

Relation of acute potassium depletion to renal ammonium metabolism in

patients with cirrhosis.

J.Clin.Invest. 42:696,1963.

130 Carter C.C., Lifton J.F., Welch M.J.

Organ uptake and blood $\mathrm{pH}$ and concentration effects of ammonia in dogs determined with ammonia labelled with 10 minutes half-lived nitrogen 13 .

Neurology 23:204,1973.

131 Shapiro A.P., Benedek Th.G., Small J.L.

Effect of thiazides on carbohydrate metabolism in patients with

hypertension.

New Engl.J.Med. 265:1028,1961.

132 Chazan J.A., Boshell B.R.

Aetiological factors in thiazide-induced or aggravated diabetes mellitus.

Diabetes 14:132,1965.

133 Skulan T.W., and Shideman F.E.

Natriuretic and antiglycogenic activities of a series of symmetrical triazine and pteridine derivates.

J. Pharmacol. Exp.Ther. 148:356,1965.

134 Unger R.H.

Glucagon physiology and pathophysiology.

New Engl.J.Med. 285:443,1971.

135 Podolsky S., Zimmerman H.J., Burrows B.A., et al.

Potassium depletion in hepatic cirrhosis.

New Engl.J.Med. 288:644,1973.

136 Munro H.N.

Mammalian protein metabolism.

Academic Press Inc. London, vol.IV, 1970.

137 Zieve L., Doizaki W.M., and Zieve F.J.

Synergism between mercaptans and ammonia or fatty acids in the production of coma: a possible role for mercaptans in the pathogenesis of 
hepatic coma.

J.Lab.Clin.Med. 83:16,1974.

138. Quantitative ammonia determination.

Standard Methods of Clinical Chemistry 5:43,1965. 



\section{Curriculum Vitae}

Peter Soeters was born on March 4th, 1941 in Amsterdam. He grew up in the village of Hoenderlo (Gelderland) and visited the Gymnasium in Apeldoorn where he passed his final exam (Gymnasium B) in 1958. He went to Medical School in Amsterdam, Municipal University.

From March 1968 to September 1969 he served Her Majesty, Queen Juliana of the Netherlands, in the military service.

He started his surgical residency training at the Surgical Department of the Andreas Ziekenhuis in Amsterdam (Heads: dr. H.J. v.d. Reyden, dr.

Groeneveld and dr. Langendijk) in October 1969. Formally, his training started in February 1971. His residency was continued in September 1971 in the St. Lucasziekenhuis in Amsterdam (Heads: dr. W.H. Brummelkamp and dr. J.M. Greep, later dr. J.M. Greep and dr. J.N. Keeman).

From November 1974 to June 1976 he worked as a clinical and research fellow in the surgical department and surgical physiology laboratory (head: dr. J.E. Fischer) of the Massachusetts General Hospital and Harvard Medical School, Boston, U.S.A.

After his return to the Netherlands, he continued his residency training at the surgical department of St. Annadal Hospital, Maastricht (heads: Prof. dr. H.A.J. Lemmens and Prof. dr. J.M. Greep). He was registered as a surgeon in August 1977.

Since then, he works as a chief-resident and clinical scientist at the surgical department of St. Annadal ziekenhuis Maastricht and University of Limburg Medical School, Maastricht. 